\title{
EVIDENCE
}

\section{EVALUATION OF VIRAL DIAGNOSTICS \\ ON RESPIRATORY INFECTIONS IN CHILDREN}

Jérôme Oscar Wishaupt 
ISBN: 978-94-6182-844-6

Cover design: Miranda Cabout

Layout and Printing: Off Page, Amsterdam, www.offpage.nl

Copyright @ 2017 Jérôme Oscar Wishaupt 


\section{EVALUATION OF VIRAL DIAGNOSTICS \\ ON RESPIRATORY INFECTIONS \\ IN CHILDREN}

Proefschrift

ter verkrijging van de graad van doctor

aan de Radboud Universiteit Nijmegen

op gezag van de rector magnificus prof. dr. J.H.J.M. van Krieken, volgens besluit van het college van decanen

in het openbaar te verdedigen op woensdag 22 november 2017

om 16.30 uur precies

door

Jérôme Oscar Wishaupt

geboren op 7 februari 1973

te Maastricht 


\section{Promotor}

Prof. dr. R. de Groot

\section{Copromotoren}

Dr. N.G. Hartwig (Franciscus Gasthuis en Vlietland, Rotterdam)

Dr. F.G.A. Versteegh (Groene Hart Ziekenhuis, Gouda)

\section{Manuscriptcommissie}

Prof. dr. H.F.L. Wertheim

Dr. ir. C.J.A. Roeleveld

Prof. dr. L.J. Bont (Universiteit Utrecht) 


\section{TABLE OF CONTENTS}

Chapter 1 General introduction and outline of this thesis 7

Chapter $2 \quad$ Clinical impact of RT-PCR for paediatric acute respiratory 31 infections: a controlled clinical trial

Pediatrics, 2011

Chapter 3 Single- and multiple viral respiratory infections in children:

disease and management cannot be related to a specific pathogen

BMC Infectious Diseases, 2017

Chapter 4 Paediatric apnoeas are not related to a specific respiratory virus, and parental reports predict hospitalisation

Acta Paediatrica, 2016

Chapter 5 Bordetella pertussis: an underreported pathogen in paediatric 85 respiratory infections, a prospective cohort study BMC Infectious Diseases, 2014

Chapter 6 Pitfalls in interpretation of CT-values of RT-PCR in children 103 with acute respiratory tract infections Journal of Clinical Virology, 2017

Chapter 7 General discussion, summarizing conclusions and future perspectives

Addendum Nederlandse samenvatting 143

Dankwoord 157

Curriculum Vitae 159

List of Publications 160

List of abbreviations 161 


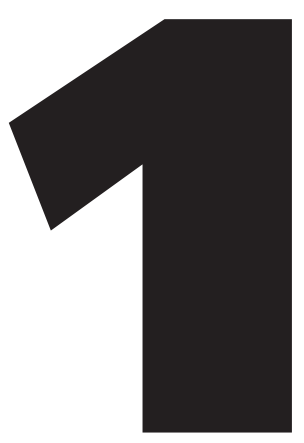




\section{GENERAL INTRODUCTION AND OUTLINE OF THIS THESIS}

Partly adapted from:

"Virale diagnostiek voor acute luchtweginfecties bij kinderen", Jérôme O. Wishaupt, Florens G.A. Versteegh, Nico G. Hartwig, Praktische Pediatrie; nr 2 - June 2015

and "PCR testing for Paediatric Acute Respiratory Tract Infections", Jérôme O. Wishaupt, Florens G.A. Versteegh, Nico G. Hartwig, Paediatric Respiratory Reviews 2015;16(1):43-48 



\section{INTRODUCTION}

In this thesis the results of the EVIDENCE trial are described, which is an acronym for "Evaluation of Viral Diagnostics on Respiratory Infections in Children". The study focuses on the diagnostic dilemmas in daily paediatric practice concerning diagnostics in young children with acute respiratory tract infections (ARI). This introductory chapter starts with a short description of clinical aspects of ARI in children, the burden of disease and the most common pathogens found in ARI. Next, the difficulties to establish a correct clinical diagnosis and to adequately assess disease severity are described. The international guidelines on viral diagnostics for ARI in children and for laboratory techniques, such as real-time reverse transcription polymerase chain reaction (RT-PCR) are subsequently discussed. At the end of this chapter we provide a short summary and the aims of the studies.

\section{WHY ARE YOUNG CHILDREN VULNARABLE TO ACUTE RESPIRATORY TRACT INFECTIONS?}

The principal function of the respiratory tract is gas exchange; it is therefore in open contact with the outside world. Airways are constantly exposed to dust and droplets that contain viruses, as well as bacteria. Mechanical defence mechanisms of the respiratory tract include the nasal hairs, the mucosa, the closure and cough reflex of the epiglottis and the cilia in the trachea and bronchi. If a pathogen passes these physical barriers, its surface antigens will activate other parts of this innate immune system which will recognize and clear foreign parts and pathogens. The cells of this system comprise granulocytes, monocytes and macrophages (phagocytosis), dendritic cells (antigen presentation cells (APC)) and natural killer cells (killing of virus infected cells). Soluble components of the innate immune system include antimicrobial proteins like lysozyme (bacterial lysis), lactoferrin (binding of iron ions), defensins (antibacterial and antiviral function), acute-phase proteins like C-reactive protein (CRP) (opsonisation, complement activation), cytokines (immune modulation) and proteins of the complement system (cell activation, cytolysis, and opsonisation). It is assumed that bacterial colonization of the upper airways has an additional role in this defence mechanism by preventing penetration of viruses and pathogenic bacteria. Early-life profiles of this respiratory microbiota composition are associated with respiratory health in children'. For a long time, it was assumed that lungs of healthy individuals were sterile. However, colonization of lower respiratory tracts and lungs with bacteria ${ }^{2}$ and fungi ${ }^{3}$ also seems to play a role in defence mechanisms to respiratory disease. This may have consequences for viral LRTI as well ${ }^{4}$.

After phagocytosis and presentation of foreign antigens at the surface of the phagocytes a second system is activated: the adaptive immune system. The cellular components are T-cells and B-cells. T-cells recognize antigens on APC which upon activation by cytokines will mature to CD4+ T-helper cells or CD8+ T-killer cells. 
This process takes place in the thymus. T-helper cells stimulate B-cells to produce immunoglobulins. T-killer cells recognize virus infected cells and kill them. The humeral component consists of immunoglobulins, produced by the B-cells. Foreign antigens bind to B-cell receptors that stimulate B-cells to transform into plasma cells, the producers of specific antibodies, or memory B-cells that can be activated quickly after a second encounter with the same antigens.

To prevent infection, neonates and infants under the age of six months are depending on an immune system that is still maturing ${ }^{5}$. The innate system is therefore the most important first line of defence. The adaptive immune system is immature, as it has not yet fully been exposed to foreign antigens. During pregnancy, maternal immunoglobulins, mainly $\lg G 1, \lg G 3$ and $\lg G 4$ cross the placenta and will help the newborn to prevent infection during the first months of life. IgM antibodies are too large to cross the placenta. IgA antibodies are transferred to the newborn by breast milk ${ }^{6}$. Other factors that may explain why young children are vulnerable to respiratory infections are their incomplete vaccination status and relatively small airways which will obstruct easily by mucus. Finally, a high exposure to respiratory viruses due to crowding by day-care attendance affects mainly children six to 12 months old 7 . These theories may in part explain the complex epidemiology of Respiratory Syncytial Virus (RSV) infection in young children. In the first months of life, RSV bronchiolitis is a relatively infrequent infection, but disease severity is severe ${ }^{8}$.

\section{BURDEN OF DISEASE}

In the Netherlands the burden of disease due to respiratory tract infections is substantial. In 2011, the incidence of episodes of lower respiratory tract infections (LRTI) in children younger than four years seeking medical help was 97 per 1000 persons; for bronchiolitis this was 61 per $1000^{9}$. In more than $50 \%$ of all febrile children presenting at a general practitioner out-of-hours service, a virus was detected $^{10}$. This is in line with reports from other developed countries, in which ARI is the most common cause for hospitalization of young children ${ }^{11}$.

Worldwide, the burden of disease is tremendous: LRTI due to Streptococcus pneumoniae, Haemophilus influenzae, Influenza virus and RSV are major causes of death in childhood. For RSV, Nair et al estimated that in 2005, 33.8 (95 \% Cl 19.3-46.2) million new episodes of RSV-associated LRTI occurred worldwide in children younger than five years, with at least 3.4 (2.8-4.3) million episodes representing severe RSV-associated LRTI necessitating hospital admission. They estimated that $66.000-$ 199.000 children younger than five years died from RSV-associated LRTI in 2005, with $99 \%$ of deaths occurring in developing countries ${ }^{12}$. 


\section{VIRUSES}

\section{Respiratory Syncytial Virus (RSV)}

RSV is a negative sense single stranded RNA virus and member of the Paramyxoviridae family, Pneumovirinae subfamily. It infects the ciliated airway epithelial cells and causes damage and inflammation. It is called "syncytial" because of its potential to induce cell fusion in cell cultures, forming syncytia ${ }^{13}$. Of all known respiratory viruses RSV seems to convey the greatest disease burden, both in hospitalized children and in outpatients, especially in children under five years of age ${ }^{14}$. Nearly all children have been infected with RSV by the age of two years ${ }^{15}$. Forty percent of children with RSV are symptomatic; two percent are admitted to a hospital and 0.1 percent to a paediatric intensive care unit. Recent work has shown an association between RSV and recurrent wheeze ${ }^{16,17}$. RSV contributes to morbidity and mortality not only in children, but also in older adults and severely immunocompromised persons ${ }^{18}$.

Thus far, guidelines on bronchiolitis advocate only supportive care like respiratory support and hydration, because evidence is lacking for efficacy of other therapeutic interventions ${ }^{19-21}$. The only prophylactic option is the monoclonal antibody Palivizumab, which reduces the incidence of severe disease and is approved for immuno-prophylaxis in Europe and in the United States ${ }^{22,23}$. However, the costs of Palivizumab are high and the indication for use is restricted to a small group of high risk infants. The virostatic drug ribavarin is no longer recommended because evidence of effectiveness is lacking ${ }^{21}$.

Current research focuses primarily on the development and clinical evaluation of new vaccines and antivirals. They target mostly on the major surface glycoprotein (G) and the fusion glycoprotein (F) of RSV, as these are the most important surface epitopes for neutralisation ${ }^{24}$. The function of the $G$ protein is to bind host cells and the function of the $F$ protein is to fuse the viral and host cell membranes by refolding from prefusion- to postfusion conformation ${ }^{25}$. Until recently, antigenic sites associated with neutralizing activity were known to exist on the highly stable postfusion conformation of the $\mathrm{F}$ protein. However, absorption of specific human neutralizing antibodies failed to remove all neutralizing activity, suggesting that neutralizing antigenic sites on the non-stable prefusion conformation must exist ${ }^{26}$. Recently, prefusion specific antibodies were identified ${ }^{27}$. This finding is important for development of new vaccines and passive preventive strategies. Indeed, promising fusion glycoprotein vaccines are already under development ${ }^{28}$. Alternative strategies are based on arresting the $\mathrm{F}$ protein in its prefusion conformation, which elicits better neutralizing antibodies ${ }^{29}$. Besides these subunit based vaccines, live attenuated vaccines are in development: genetically modified live viruses with low virulence will induce maximum immunogenicity. Furthermore, vector based vaccines try to transport RSV viral proteins through another, more stable virus into the host. New antiviral strategies consist of immunoglobulins, siRNA-interference, fusion inhibitors and small 
molecules ${ }^{30}$. Nowadays, immunoglobulins are studied in phase one and two clinical trials. Overview of new vaccine strategies and antivirals and their developmental stage are recently published ${ }^{30,31}$.

\section{Influenza virus (FLU)}

Influenza (FLU) viruses are negative sense single stranded RNA viruses and family of the Orthomyxovirida. They are distinguished into subtypes A, B and C. Subtypes A and $B$ are well known for their seasonal outbreaks of ARI during a few weeks in winter, and also for a sepsis like syndrome without respiratory symptoms in children under six months of age ${ }^{32}$. FLU subtype A can be divided into different serotypes, based on the hemagglutinin $(\mathrm{H})$ and neuraminidase $(\mathrm{N})$ surface glycoproteins. Examples are H1N1 (1918 Spanish flu), H2N2 (1957 Asian flu, H3N2 (1968 Hong Kong flu), H1N1 (1977 Russian flu), H5N1 (1997 bird flu), H1N1 (2009 swine flu) and H7N9 (2013, severe illness mainly in China). H1N1, H3N2 and B viruses are circulating in epidemics for the last decades ${ }^{32}$. Antigenic drift causes small mutations in these $\mathrm{H}$ and $\mathrm{N}$ genes, making it unrecognizable to pre-existing host immunity, leading to these seasonal outbreaks. Antigenic shift leads to a complete new subtypes and occasionally to pandemics ${ }^{13}$. The surface proteins are also targets for antiviral drugs. There is limited evidence that early treatment with the neuraminidase inhibitor oseltamivir will reduce mortality, hospitalisation and duration of symptoms ${ }^{33}$. Vaccination is the cornerstone of prevention and yearly revision of the antigenic composition is needed to accommodate the changes in the hemagglutinin antigens of the virus.

\section{Human Metapneumovirus (hMPV)}

hMPV, a negative sense single stranded RNA virus, is like RSV a family member of the Paramyxoviridae family, Pneumovirinae subfamily. It was first detected in $2001^{34}$. As reviewed by Schildgen et al, similar to RSV, F- and G proteins are important surface epitopes and different genetic lineages $A$ and $B$ do exist. Infections occur worldwide, through the year, with the peak incidence in winter, one to two months after the peak incidence of RSV. hMPV infection occurs at all ages, with a high prevalence in children, starting at the age of six months. High seroprevalence rates are reached from five years of age. Clinical symptoms overlap with those of other respiratory viruses $^{35}$. Disease severity seems less than for RSV ${ }^{36}$.

\section{Para-influenza viruses (PIV)}

PIVs are negative sense single stranded RNA viruses and are also member of the Paramyxoviridae family, Paramyxovirinae subfamily. The name was chosen because of causing influenza-like symptoms and containing hemagglutination and neuraminidase activities ${ }^{13}$. PIV subtypes one and two are known to cause spasmodic 
croup and subtype three is known to cause bronchiolitis and pneumomia ${ }^{37}$. PIV subtype four has been reported to be a much less frequent cause of $A R I^{38}$.

\section{Human Rhinovirus (HRV)}

$H R V$, a positive sense single stranded RNA virus, is an enterovirus of the Picornaviridae family. Known subtypes are HRV-A, HRV-B and HRV-C. Within these subtypes, isolates are subdivided into numeric genotypes. HRV is generally associated with the common cold, can cause severe ARI as well and is the most common pathogen in ARI in young children ${ }^{39,40}$. Re-infections with HRV are commonly observed, and are usually caused by different virus strains ${ }^{41}$. As reviewed by Kim, recent studies suggest that HRV subtype C may be more virulent than other HRV42, but not all RT-PCRs are capable of distinguishing between the different HRV strains. Studies on recurrent wheeze and asthma development suggest not only a role for RSV, but also for HRV ${ }^{43}$.

\section{Enterovirus D68}

Another virus that is associated with respiratory illness is Enterovirus D68, a positive sense single stranded RNA virus and also member of the Picornaviridae family. The virus is already circulating for decades. Occasionally there are outbreaks, such as 2010 in the Netherlands in young children ${ }^{44}$ and at the end of 2014 in the United States $^{45}$. In the summer of 2016, there was also an outbreak in the Netherlands leading to hospitalization of many children (National Institute for Public Health and the Environment, the Netherlands, 2016, unpublished data). Disease severity from Enterovirus D68 is especially high in children with underlying pulmonary disease ${ }^{46}$.

\section{Human adenovirus (HAdV)}

HAdV, a double stranded DNA virus and member of the Adenoviridae family, is subdivided in 57 serotypes in seven species typed A to G. HAdV causes gastrointestinal diseases, acute hemorrhagic cystitis, meningoencephalitis and myocarditis. The common serotypes associated with ARI are HAdV1, 2, 5, and 6 (species C) and occasionally HAdV3 and HAdV7 (species B) ${ }^{13}$. HAdV is associated with a severe course in children with underlying immunodeficiency ${ }^{47}$. Pneumonia due to HAdV is also accociated with high levels of CRP and leukocytosis ${ }^{48}$.

\section{Human Bocavirus (HBoV)}

Another 'new' virus is HBoV, discovered in $2005^{49}$. This single stranded DNA virus is a member of the Parvoviridae family and is named after its similarity with bovine parvovirus and canine minute virus ${ }^{50}$. In a review by Brodzinsky, the incidence was found to be low (1.5-4.5\%) and rates of co-infections were high (14-72\%) ${ }^{51}$. However, HBoV in absence of other pathogens can cause severe ARI in children as well ${ }^{52}$. Prolonged detection of HBoV after primary infection is reported for up to a year ${ }^{53}$. The spectrum of disease is similar to RSV and hMPV. 


\section{Human Coronaviruses (HCoV)}

HCoVs are positive sense single stranded RNA viruses and belong to the Coronaviridae family. They comprise a heterogeneous group. HCoV $229 \mathrm{E}^{54}, \mathrm{OC} 43^{55}, \mathrm{NL}^{5} 3^{56,57}$ and HKU $1^{58}$ are diagnosed frequently in young age and are correlated with less severe respiratory disease ${ }^{59}$. On the other hand, 'Severe Acute Respiratory SyndromeCoronavirus' (SARS-CoV) is known for its outbreak with high mortality in the year $2002^{60}$. The novel 'Middle East Respiratory Syndrome-Coronavirus' (MERS-CoV) was causing an outbreak of severe respiratory disease in some countries of the Middle East, first in the year 201261. Dromedary camels played an important role in transmission. SARS-CoV and MERS-CoV are not routinely incorporated in respiratory RT-PCR test panels.

\section{Polyomaviruses}

The incidence of the double stranded DNA polyomaviruses $\mathrm{WU}^{62}$ and $\mathrm{KI}^{63}$ is low and their clinical relevance remains unclear and requires further evaluation ${ }^{64}$. Recently, a potential pathogenic role of KI was suggested ${ }^{65}$.

\section{Multiple-viral infections}

The incidence of multiple-viral infections in one single patient is reported as high as $14-44 \%$, depending on different populations and test panels ${ }^{66}$. In a multicentre study, involving 2207 children less than two years of age, the incidence of multiple infections in children hospitalized for bronchiolitis was 30 percent ${ }^{67}$. It is hypothesized that multiple infections may lead to a more severe disease. However, papers on this subject show contradictory results. There are some reports suggest that there is no relation between multiple viral ARI and disease severity ${ }^{68-71}$, while others indicate a higher disease severity in children with a mixed respiratory infection ${ }^{72,73}$.

\section{BACTERIA}

Streptococcus pneumoniae, Haemophilus influenzae type B, Moraxella catarrhalis and Staphylococcus aureus are normal commensals in the respiratory tract, but may also cause severe ARI in children. The incidence of infection with Streptococcus pneumoniae and Haemophilus influenzae decreased dramatically in the last ten years after implementation of vaccine programmes.

Bordetella pertussis is a well-known cause of ARI in children as well. It has a wide spectrum of disease, ranging from classical presentation with paroxysmal cough and hypoxic episodes to mild disease and rhinitis, almost indistinguishable from a viral infection. Other species than Bordetella pertussis, like Bordetella parapertussis, and Bordetella holmesii have been associated with pertussis-like illness too ${ }^{74}$. Pertussis toxin seems to play a major role in pertussis pathology, including the severe respiratory symptoms ${ }^{75}$. In the last decade, the incidence of infections with Bordetella 
pertussis has increased, even in countries with high vaccination coverage, particularly in adolescents and adults ${ }^{76}$. Recently, also vaccine-component escaping variants have been discovered, but the impact on vaccine effectiveness is unknown ${ }^{77}$. It is known that vaccine effectiveness of the whole cell vaccine has a longer duration than that the acellular vaccine, but duration of protection against disease after natural infection is better than the duration of protection by both vaccines. Current research focuses on new vaccination strategies and a better understanding of the immune response against Bordetella pertussis. Recently, the World Health Organization (WHO) recommended vaccination during pregnancy as an additional strategy to routine infant vaccinations in order to prevent pertussis in newborns ${ }^{78}$. In the Netherlands, The Health Council of the Netherlands, an independent scientific advisory body for the government underlines this recommendation. At this moment, cost aspects are discussed by the Dutch minister of health.

The role of other pathogens, such as Mycoplasma pneumoniae and Chlamydophyla pneumoniae is subject of debate in recent studies ${ }^{79}, 80$. Detection of these pathogens is not always related to respiratory disease.

Bacteria may mimic viral disease as well, especially in young children ${ }^{81}$. Besides this, bacterial - viral interactions seem to occur frequently. For example, in patients with FLU, mortality increases dramatically when a super-infection with Streptococcus pneumoniae occurs ${ }^{82}$. Another example is the interaction between FLU and Bordetella pertussis. In mice models, pertussis toxin activity seems to predispose the host to exacerbated influenza by suppression of the innate immune system ${ }^{83}$. In a recent paper, a multidimensional interaction model is proposed that underlines the complexity of interactions between bacteria and viruses in the respiratory tract and further research on this topic may hopefully lead to better insight into pathogenesis of respiratory disease ${ }^{84}$.

\section{CLINICAL DIAGNOSIS}

The anatomic approach to ARI creates two categories: upper respiratory tract infection (URTI) and LRTI. URTI is confined to the ear, nose and throat region and is considered to be a rather harmless disease for which medical attention is generally restricted to family care. LRTI on the contrary, which involves the bronchi, bronchioli and the lung tissue, is considered a more severe disease and is often seen by paediatricians. However, in paediatric patients a clear distinction between URTI and LRTI is difficult to make and appears not useful for clinical decision-making. In infants, classical LRTI-symptoms like tachypnea or hypoxia are also common in paediatric URTI due to nasal obstruction and mucus plugging of the anatomically small upper airways. General symptoms such as poor feeding, lowered alertness and low transcutaneous oxygen seem to influence the clinical course more strongly than the designated anatomical site of infection ${ }^{85}$. 
LRTI can be subdivided in pneumonia and bronchiolitis on the basis of pathophysiologic mechanisms. Pneumonia reflects inflammation of lung tissue (bronchi, bronchioles and alveolar tissue) in response to infection by bacterial, viral or other pathogens, while bronchiolitis primarily affects the small airways (bronchioles) and is usually of viral origin only. The clinical presentation of pneumonia overlaps substantially with that of bronchiolitis and vice versa. Pneumonia and bronchiolitis are clinical diagnoses without an internationally standardized test or definition ${ }^{86,87}$. Though chest radiographs are often used in clinical settings, they cannot distinguish between these two conditions ${ }^{88}$.

There have been attempts to distinguish viral from bacterial ARI. Most paediatric $A R I$ are of viral origin and the risk of concurrent (or subsequent) bacterial infection has been reported to be low in children over three months of age ${ }^{89}$. It is assumed that antibiotics are prescribed too often for these children ${ }^{90}$. This is in part explained by a high level of similarity in clinical symptoms between viral and bacterial LRTI. Respiratory Syncytial Virus (RSV) pneumonia and serologically detected pneumococcal pneumonia for instance do have considerably over-lapping clinical signs and symptoms, whereas laboratory and chest radiography findings may differ significantly ${ }^{91}$. In this study from Juven et al, white blood count and CRP levels were significantly lower in RSV pneumonia in relation to Streptococcus pneumoniae. Although CRP is frequently used as a marker for bacterial pneumonia, its role remains unclear. In a meta-analysis of 1230 children with pneumonia, a CRP level exceeding 40-60 mg/L weakly predicted a bacterial etiology 92 . Another biomarker of interest is procalcitonin. Its blood levels increase more rapidly than CRP after bacterial infection ${ }^{93}$ and its overall sensitivity and specificity for paediatric bacterial infection is better than CRP ${ }^{94}$. The efficacy and safety of procalcitonin as a diagnostic tool for reducing antibiotic therapy in neonates with suspected early onset sepsis is studied in an international randomized controlled trial. This "Neopins study" showed that standardised risk assessment and procalcitonin-guided decision making reduced the duration of antibiotic therapy and hospital stay, with a low rate of re-infection and without study-related mortality ${ }^{132}$.

\section{ASSESSMENT OF DISEASE SEVERITY AND RISK FACTORS}

The majority of paediatric patients with ARI are young and previously healthy children with no known risk factors for acquiring respiratory infection. Assessment of disease severity in these children is based on patient's history, parental concern and objective findings by physical examination. Different clinical scoring systems are in use, adapted to local circumstances and patient groups. Examples are: The Respiratory Distress Assessment Instrument, based on wheezing and retractions ${ }^{95}$, the (Bedside) Paediatric Early Warning Sign Scores ${ }^{96-98}$, the Preschool Respiratory Assessment Measure ${ }^{99}$, the clinical scoring system described by Kristjansson ${ }^{100}$, the Silverman-Anderson Respiratory Scale ${ }^{101}$, the Global respiratory Severity Score (GRSS) for RSV infection in 
infants $^{102}$, the disease severity score by Gern ${ }^{103}$ and the ReSVinet Scale ${ }^{104}$. However, none of the above scoring systems has been validated specifically for prediction of clinical outcome in paediatric ARI. This diversity in scoring systems limits comparison of study data in the literature.

Assessment of respiratory illness in children with underlying conditions is even more difficult. Known risk factors for severe bronchiolitis are best recognized for RSV. These include young age, prematurity, low birth weight, Down syndrome, congenital heart disease, bronchopulmonary disease and immunodeficiency ${ }^{105}$, 106 . Other underlying conditions that lead to higher hospitalisation rates are cerebral palsy, chronic lung diseases like cystic fibrosis, asthma and recurrent respiratory tract infections.

\section{POTENTIAL BENEFITS OF A RAPID VIRAL DIAGNOSIS}

A rapid and accurate viral diagnosis may be beneficial for clinical paediatric practice with respect to:

- Prognosis: the first symptom of an ARI is often fever. The paediatrician has to decide in an early stage at presentation of first symptoms whether a young patient suffers from a potentially harmful disease for which immediate treatment is required or not.

- Complications: early intervention in a disease period and disease specific therapy such as anti-viral drugs can prevent complications.

- Antibiotics: as viral and bacterial ARI do have overlapping symptoms, one might expect that a rapid and adequate viral diagnosis will contribute to a reduction of unnecessary antibiotic use; not to start antibiotics at all, or to stop antibiotics at an early stage.

- Cohorting of inhospital patients and prevention of nosocomial infections: hygienic measurements and isolation strategies should ideally gear to the isolated microorganisms.

- Hospitalization: some children may not be hospitalized if a diagnosis is recognized in an early stage for which intervention at a paediatric ward is not necessary.

- Length of hospital stay: some hospitalized children might be discharged from a paediatric ward at an early stage if one might expect that the disease course can be monitored at the outpatient clinic.

\section{(INTER)NATIONAL GUIDELINES REGARDING USE OF VIRAL DIAGNOSTICS IN PAEDIATRIC ARI}

There are different international and national guidelines regarding use of viral diagnostics in paediatric ARI, which are summarized below. 
The Pediatric Infectious Disease Society (PIDS) and the Infectious Diseases Society of America (IDSA) recommend in their guideline 'Community-Acquired Pneumonia (CAP) in Infants and Children' the use of sensitive and specific tests for the rapid diagnosis of influenza virus and other respiratory viruses in the evaluation of children older than three months of age with CAP ${ }^{107}$. In the case of a positive test for influenza, they strongly recommend that no antibiotic therapy should be employed in the absence of clinical, laboratory or radiographic findings suggestive for bacterial co-infection. No specific recommendation is given on antibiotic use when other viruses are detected. Currently, there are no (P)IDSA guidelines for paediatric $A R I$ in patients younger than three months.

The American Association of Pediatrics (AAP) recommends clinicians to diagnose bronchiolitis and assess disease severity on the basis of history and physical examination without routinely ordering laboratory tests or radiography to make the diagnosis ${ }^{108}$. Clinicians should assess risk factors for severe disease (age less than 12 weeks, prematurity, underlying cardiopulmonary disease or immunodeficiency) (evidence level B). Repeated observations over a short period of time will improve overall assessment and patient care. In a state of the art review in 2010, this AAP recommendation is supported by evidence of a low rate of bacterial co-infection in children younger than three months of age presenting with bronchiolitis ${ }^{109}$. However, rates of RSV testing did not fall after publication of the 2006 guidelines ${ }^{110}$. The authors suggest that hospitals continue to test for RSV in order to cohort patients after admission.

The guidelines of the Royal College of Paediatrics and Child Health (RCPCH) and the European Society of Paediatric Infectious Diseases (ESPID) recognize that rapid, sensitive and specific immunofluorescence viral tests are available and that RT-PCR is increasingly replacing immunofluorescence and serology, but they do not give recommendations when to use it and what the consequences are of the results when they become available ${ }^{111}$. The National Institute for Health and Care Excellence (NICE) of the United Kingdom does not have recommendations when to use viral diagnostics for ARI in children ${ }^{19}$.

The Dutch Paediatric Association (Nederlandse Vereniging voor Kindergeneeskunde, NVK) states that bronchiolitis is a "clinical diagnosis". In their guideline for bronchiolitis, they recommend to perform viral diagnostics on a nasopharyngeal aspirate "only in case the result of the test is important for clinical management and / or organization of the paediatric ward with regard to isolation measurements" 20 . What or when is important, remains unclear in this guideline.

\section{CONVENTIONAL VIRAL DIAGNOSTICS IN PAEDIATRIC ARI}

Until the 1980's, viral testing was not routinely available in paediatric clinical practice. Viral cultures were the gold standard, but they require specialized laboratory facilities and are time-consuming. Therefore, results are usually available too late to influence 
patient management. Serology is more easy to implement, but usually requires two separate blood samples over time to show (preferably) a four-fold increase in antibody response, unless a cut-off is established for one-point serology. Blood sampling is not a child-friendly procedure and the results are also not readily available. The use of serology seems restricted to epidemiologic studies in order to maximize etiologic diagnosis ${ }^{112}$. Rapid antigen tests like direct immunofluorescent antibody tests (DFA) provide more rapidly results, but are less sensitive than viral cultures ${ }^{113,114}$. They are available for RSV and influenza virus, but sensitivity ranges from $66.2 \%$ to $94.1 \%^{115-118}$. According to earlier studies, rapid viral tests contribute to reduction in hospital stay and antibiotic use $\mathrm{e}^{90,119-121}$.

\section{INTRODUCTION OF VIRAL PCR TECHNIQUES IN PRACTICE}

Since the 1990's PCR techniques have become widely available. Conventional endpoint single-target PCRs were able to report positive and negative results of RNA and DNA viruses. Later on, computerized quantitative RT-PCRs were able to correlate the amount of PCR product to a viral load. Testing a panel of respiratory viruses within a time span of 6 to 24 hours has become routine practice in many hospitals in high income countries. In paediatric populations, the sensitivity has shown to be higher than for viral culture ${ }^{113}$. Nowadays, qualitative and even quantitative multiplex PCRs are able to detect multiple respiratory viruses in one single sample simultaneously. However, sensitivity in a multiplex PCR is generally lower than in single target RT-PCR ${ }^{122}$. A disadvantage of commercially available multiplex PCRs is that the tests require external controls, which are difficult to perform since not all available platforms publish their targets ${ }^{123}$. Despite the availability of commercially quantitative multiplex PCRs, in-house quantitative single target RT-PCRs are used more frequently in current laboratory practice.

In a recent review by Jartti et al on new molecular virus detection methods, all nasopharyngeal sampling tests, including nasopharyngeal aspirates, washes, swabs or brush appear suitable for PCR analysis. Viruses in the upper airways do reflect infections of the lower airways ${ }^{122}$. Sputum induction methods, trying to generate sputum samples from the lower respiratory tract are not recommended for routine use as the diagnostic yield will not significantly improve.

A possible advantage of RT-PCR is its property of generating quantitative results. An objective laboratory parameter, reflecting disease severity, would be helpful to estimate disease course in an early stage. Viral load was thought to serve as such a parameter. Viral load is the quantity or copy number of viral RNA or DNA detected per millilitre body fluid. In RT-PCR, the cycle threshold (CT) value is defined as the number of RT-PCR cycles required for a positive fluorescent amplification signal to cross the threshold. This is inversely correlated with the viral load. Some authors indeed found a significant correlation between viral load and disease 
severity 124-126, thereby justifying broad use of RT-PCR. However viral load does not always correlate well to disease severity ${ }^{127-131}$. Some viruses, like RSV, are short lived and others like HBoV are long-lived, which is a complicating factor in demonstrating this relationship. The question how well disease severity is correlated with viral load is not answered yet.

\section{STRUCTURE AND AIMS OF THIS THESIS}

As stated above, clinical decision making in ARI is based on interpretation of clinical signs and symptoms, often supported with results of laboratory parameters such as $C$-reactive protein and white blood count combined with conventional viral tests and X-rays. Detection of bacteria is often not helpful in clinical decision making, as bacteria are normal commensals in the nose-throat region and even in the lower airways and lungs.

New molecular tests to detect viruses have been introduced in many hospitals. However the role and impact of these molecular tests in clinical decision making is not studied well. This thesis focuses primarily on the role of viral diagnostics in relation to patient care in paediatric ARI. In a pilot study, the local standard of care concerning viral diagnostics and patient care was investigated, including turnaround times of viral RT-PCR procedures and logistics of reporting results to the paediatrician.

The main research questions were the following:

- What is the clinical impact of introducing RT-PCR diagnostics for ARI in daily practice of paediatricians (Chapter 2)? Does a rapid and accurate viral diagnosis lead to changes in patient management and outcome like hospitalization, length of hospital stay, antibiotic treatment and even mortality?

- $\quad$ RT-PCR is a high sensitive technique and generates a great amount of positive test results. What is the clinical relevance of finding each individual virus and what is the relevance of finding multiple viruses in one single patient (Chapter 3)? Is there a relationship between specific viruses and laboratory parameters like C-reactive protein and white blood count?

- What is the frequency of apnoeas in previously healthy young children with $\mathrm{ARI}$ and what is the correlation with the isolated micro-organisms, clinical findings, disease severity and outcome (Chapter 4)?

- Viral ARI and bacterial ARI do have a great overlap in presenting symptoms. What is the frequency of pertussis in clinically unsuspected cases compared to suspect cases and can we define clinical predictors of pertussis (Chapter 5)?

- Is the CT value of RT-PCR, which is inversely correlated with viral load helpful in clinical decision making and assessment of disease severity in ARI (Chapter 6)? 


\section{REFERENCE LIST}

1. Biesbroek G, Tsivtsivadze E, Sanders EAM, Montijn R, Veenhoven $\mathrm{RH}^{+}$, Keijser BJF and Bogaert $D$. Early respiratory microbiota composition determines bacterial succession patterns and respiratory health in children. Am J Respir Crit Care Med 2014;190(11):1283-1292.

2. Dickson RP, Erb-Downward JR, Freeman CM, McCloskey L, Falkowski NR, Huffnagle GB and Curtis JL. Bacterial Topography of the Healthy Human Lower Respiratory Tract. MBio 2017;8(1).

3. Krause R, Moissl-Eichinger C, Halwachs B, Gorkiewicz G, Berg G, Valentin T, Prattes J, Högenauer $C$ and Zollner-Schwetz I. Mycobiome in the Lower Respiratory Tract - A Clinical Perspective. Front Microbiol 2016;7:2169.

4. Bellinghausen C, Rohde GG, Savelkoul PH, Wouters EF, Stassen FR. Viral-bacterial interactions in the respiratory tract. J Gen Virol 2016;97(12):3089-3102.

5. Levy O. Innate immunity of the newborn: basic mechanisms and clinical correlates. Nat Rev Immunol 2007;7(5):379-390.

6. Weaver LT, Arthur HM, Bunn JE, Thomas JE. Human milk IgA concentrations during the first year of lactation. Arch Dis Child 1998;78(3):235-239.

7. de Hoog MLA, Venekamp RP, van der Ent CK, Schilder A, Sanders EAM, Damoiseaux RAMJ, Bogaert D, Uiterwaal CSPM, Smit HA and Bruijning-Verhagen P. Impact of early daycare on healthcare resource use related to upper respiratory tract infections during childhood: prospective WHISTLER cohort study. BMC Med 2014;12:107.

8. Bont LJ, Houben ML. Commentary: why are young healthy term infants protected against respiratory syncytial virus bronchiolitis? Pediatr Infect Dis J 2011;30(9):785-786.

9. Volksgezondheid en Zorg: https://www.volksgezondheidenzorg.info/onderwerp/infectiesvan-de-onderste-luchtwegen/cijfers-context/incidentie. 2016. Online Source

10. Kool M, Monteny M, van Doornum GJ, Moll HA, Berger MY. Respiratory virus infections in febrile children presenting to a general practice out-of-hours service. Eur J Gen Pract 2015;21(1):5-11.

11. Yorita KL, Holman RC, Sejvar JJ, Steiner CA, Schonberger LB. Infectious disease hospitalizations among infants in the United States. Pediatrics 2008;121(2):244-252.

12. Nair H, Nokes DJ, Gessner BD, Dherani M, Madhi SA, Singleton RJ, O'Brien KL, Roca A, Wright PF, Bruce N, Chandran A, Theodoratou E, Sutanto A, Sedyaningsih ER, Ngama M, Munywoki PK, Kartasasmita C, Simões EAF, Rudan I, Weber MW and Campbell H. Global burden of acute lower respiratory infections due to respiratory syncytial virus in young children: a systematic review and meta-analysis. Lancet 2010;375(9725):1545-1555.

13. Fields BN, . Fields Virology. 6 ed. Lippincott Williams \& Wilkins, a Wolters Kluwer business; 2013.

14. Hall CB, Weinberg GA, Iwane MK, Blumkin AK, Edwards KM, Staat MA, Auinger P. Griffin MR, Poehling KA, Erdman D, Grijalva CG, Zhu Y and Szilagyi P. The burden of respiratory syncytial virus infection in young children. N Engl J Med 2009;360(6):588-598.

15. Glezen WP, Taber LH, Frank AL, Kasel JA. Risk of primary infection and reinfection with respiratory syncytial virus. Am J Dis Child 1986;140(6):543-546.

16. Blanken MO, Rovers MM, Molenaar JM, Winkler-Seinstra PL, Meijer A, Kimpen JLL and Bont LJ, for the Dutch RSV Neonatal Network Respiratory syncytial virus and recurrent wheeze in healthy preterm infants. N Engl J Med 2013;368(19):1791-1799.

17. Zomer-Kooijker K, van der Ent CK, Ermers MJ, Uiterwaal CS, Rovers MM, Bont LJ. Increased risk of wheeze and decreased lung function after respiratory syncytial virus infection. PLoS One 2014;9(1):e87162. 
18. Walsh EE. Respiratory Syncytial Virus Infection: An Illness for All Ages. Clin Chest Med 2017;38(1):29-36.

19. National Institute for Health and Care Excellence. Bronchiolitis in children: diagnosis and management. https://www.nice.org.uk/guidance/ng9/chapter/1Recommendations\#assessment-and-diagnosis. 2016. Online Source.

20. The Paediatric Association of The Netherlands, Bronchiolitis Guideline. http://www.nvk.nl/ Portals/0/richtlijnen/bronchiolitis/richtlijnbronchio.pdf. 2016. Online Source.

21. Ralston SL, Lieberthal AS, Meissner, Alverson BK, Baley JE, . Gadomski AM, Johnson DW, Light MJ, Maraqa NF, Mendonca EA, Phelan KJ, Zorc JJ, Stanko-Lopp D, Brown MA, Nathanson I, Rosenblum E, Sayles III SS and Hernandez-Cancio S, Clinical practice guideline: the diagnosis, management, and prevention of bronchiolitis. Pediatrics 2014;134(5):e1474e1502.

22. Johnson S, Oliver C, Prince GA, Hemming VG, Pfarr DS, Wang SC, Dormitzer M, O'Grady J, Koenig S, Tamura JK, Woods R, Bansal G, Couchenour D, Tsao E, Hall WC and Young JF. Development of a humanized monoclonal antibody (MEDI-493) with potent in vitro and in vivo activity against respiratory syncytial virus. J Infect Dis 1997;176(5):1215-1224.

23. The IMpact-RSV Study Group. Palivizumab, a humanized respiratory syncytial virus monoclonal antibody, reduces hospitalization from respiratory syncytial virus infection in high-risk infants. Pediatrics 1998;102(3 Pt 1):531-537.

24. McLellan JS, Ray WC and Peeples ME. Structure and function of respiratory syncytial virus surface glycoproteins. Curr Top Microbiol Immunol 2013;372:83-104.

25. Collins PL and Melero JA. Progress in understanding and controlling respiratory syncytial virus: still crazy after all these years. Virus Res 2011;162(1-2):80-99.

26. Magro M, Mas V, Chappell K, Vázquez M, Cano O, Luque D, Terrón MC, Melero JA and Palomo C. Neutralizing antibodies against the preactive form of respiratory syncytial virus fusion protein offer unique possibilities for clinical intervention. Proc Natl Acad Sci USA 2012;109(8):3089-3094.

27. McLellan JS, Chen M, Leung S, Graepel KW, DuX, Yang Y, Zhou T, Baxa U, Yasuda E, Beaumont T, Kumar A, Modjarrad K,Zheng Z, Zhao M, Xia N, Kwong PD and Graham BS. Structure of RSV fusion glycoprotein trimer bound to a prefusion-specific neutralizing antibody. Science 2013;340(6136):1113-1117.

28. McLellan JS, Chen M, Joyce MG, Sastry M, Stewart-Jones GB, Yang Y, Zhang B, Chen L, Srivatsan S, Zheng A, Zhou T, Graepel KW, Kumar A, Moin S, Boyington JC, Chuang GY, Soto C, Baxa U, Bakker AQ, Spits H, Beaumont T, Zheng Z, Xia N, Ko SY, Todd JP, Rao S, Graham BS and Kwong PD. Structure-based design of a fusion glycoprotein vaccine for respiratory syncytial virus. Science 2013;342(6158):592-598.

29. Krarup A, Truan D, Furmanova-Hollenstein $P_{1}$ Bogaert L, Bouchier $P_{1}$ Bisschop IJM, Widjojoatmodjo MN, Zahn R, Schuitemaker H, McLellan JS and Langedijk JPM. A highly stable prefusion RSV F vaccine derived from structural analysis of the fusion mechanism. Nat Commun 2015;6:8143.

30. Mazur NI, Martinon-Torres F, Baraldi E, Fauroux B, Greenough A, Heikkinen T, Manzoni $P_{1}$ Mejias A, Nair H, Papadopoulos NG, Polack FP, Ramilo O, Sharland M, Stein R, Madhi SA and Bont LJ, in collaboration with Respiratory Syncytial Virus Network (ReSViNET). Lower respiratory tract infection caused by respiratory syncytial virus: current management and new therapeutics. Lancet Respir Med 2015;3(11):888-900.

31. Mejias $A$ and Ramilo $O$. New options in the treatment of respiratory syncytial virus disease. J Infect 2015;71 Suppl 1:S80-S87. 
32. Sharland M. Influenza and parainfluenza. Manual of Childhood Infections, The Blue Book. 2016:628-632.

33. Santesso N, Hsu J and Mustafa R. Antivirals for influenza: a summary of a systematic review and meta-analysis of observational studies. Influenza Other Respir Viruses 2013;7 Suppl 2:76-81.

34. van den Hoogen BG, de Jong JC, Groen J, Kuiken T, de Groot R, Fouchier RAM and Osterhaus ADME. A newly discovered human pneumovirus isolated from young children with respiratory tract disease. Nat Med 2001;7(6):719-724.

35. Schildgen $V$, van den Hoogen BG, Fouchier RAM, Tripp RA, Alvarez R, Manoha C, Williams $\mathrm{J}$ and Schildgen O. Human Metapneumovirus: lessons learned over the first decade. Clin Microbiol Rev 2011;24(4):734-754.

36. van den Hoogen BG, Osterhaus ADME, Fouchier RAM. Clinical impact and diagnosis of human metapneumovirus infection. Pediatr Infect Dis J 2004;23(1 Suppl):S25-S32.

37. Weinberg GA, Hall CB, Iwane MK, Poehling KA, Edwards KM, Griffin MR, Staat MA, Curns $A T$, Erdman DD, Szilagyi $P G$, for the new vaccine surveillance network. Parainfluenza virus infection of young children: estimates of the population-based burden of hospitalization. J Pediatr 2009;154(5):694-699.

38. Billaud G, Morfin F, Vabret A, Boucher A, Gillet Y, Crassard N, Galambrun C, Ferraris O, Legrand L, Aymard M, Lina B, Freymuth F, and Thouvenot D. Human parainfluenza virus type 4 infections: a report of 20 cases from 1998 to 2002. J Clin Virol 2005;34(1):48-51.

39. Kieninger $E$, Fuchs $O$, Latzin P, Frey $U$ and Regamey N. Rhinovirus infections in infancy and early childhood. Eur Respir J 2013;41(2):443-452.

40. Winther B, Hayden FG and Hendley JO. Picornavirus infections in children diagnosed by RTPCR during longitudinal surveillance with weekly sampling: Association with symptomatic illness and effect of season. J Med Virol 2006;78(5):644-650.

41. Jartti T, Lee WM, Pappas T, Evans M, Lemanske RF, Jr. and Gern JE. Serial viral infections in infants with recurrent respiratory illnesses. Eur Respir J 2008;32(2):314-320.

42. Kim WK and Gern JE. Updates in the relationship between human rhinovirus and asthma. Allergy Asthma Immunol Res 2012;4(3):116-121.

43. Jartti T and Korppi M. Rhinovirus-induced bronchiolitis and asthma development. Pediatr Allergy Immunol 2011;22(4):350-355.

44. Meijer A, van der Sanden S, Snijders BE, Jaramillo-Gutierrez G, Bont LJ, van der Ent CK, Overduin P, Jenny SL, Jusic E, van der Avoort HG, Smith GJ, Donker GA and Koopmans MP. Emergence and epidemic occurrence of enterovirus 68 respiratory infections in The Netherlands in 2010. Virology 2012;423(1):49-57.

45. Messacar K, Abzug MJ and Dominguez SR. 2014 outbreak of enterovirus D68 in North America. J Med Virol 2016;88(5):739-745.

46. Schuster JE, Miller JO, Selvarangan R. Weddle G, Thompson MT, Hassan F, Rogers SL, Steven Oberste M, Allan Nix W, Jackson M. Severe enterovirus 68 respiratory illness in children requiring intensive care management. J Clin Virol 2015;70:77-82.

47. Walls T, Shankar AG, Shingadia D. Adenovirus: an increasingly important pathogen in paediatric bone marrow transplant patients. Lancet Infect Dis 2003;3(2):79-86.

48. Chen SP, Huang YC, Chiu CH Wong KS, Huang YL, Huang CG, Tsao KC and Lin TY. Clinical features of radiologically confirmed pneumonia due to adenovirus in children. J Clin Virol 2013;56(1):7-12. 
49. Allander T, Tammi MT, Eriksson M, Bjerkner A, Tiveljung-Lindell A and Andersson B. Cloning of a human parvovirus by molecular screening of respiratory tract samples. Proc Natl Acad Sci USA 2005; 102(36):12891-12896.

50. Jartti T, Hedman K, Jartti L, Ruuskanen O, Allander T and Soderlund-Venermo M. Human bocavirus-the first 5 years. Rev Med Virol 2012;22(1):46-64.

51. Brodzinski $\mathrm{H}$ and Ruddy RM. Review of new and newly discovered respiratory tract viruses in children. Pediatr Emerg Care 2009;25(5):352-360.

52. Moesker FM, van Kampen JJ, van Rossum AMC, de Hoog M, Koopmans MPG, Osterhaus ADME and Fraaij PLA. Viruses as Sole Causative Agents of Severe Acute Respiratory Tract Infections in Children. PLoS One 2016;11(3):e0150776.

53. Martin ET, Kuypers J, McRoberts JP, Englund JA and Zerr DM. Human Bocavirus 1 Primary Infection and Shedding in Infants. J Infect Dis 2015;212(4):516-524.

54. Hamre $D$ and Procknow JJ. A new virus isolated from the human respiratory tract. Proc Soc Exp Biol Med 1966;121(1):190-193

55. McIntosh K, Dees JH, Becker WB, Kapikian AZ and Chanock RM. Recovery in tracheal organ cultures of novel viruses from patients with respiratory disease. Proc Natl Acad Sci USA 1967;57(4):933-940.

56. Fouchier RAM, Hartwig NG, Bestebroer TM, Niemeyer B, de Jong JC, Simon JH and Osterhaus ADME. A previously undescribed coronavirus associated with respiratory disease in humans. Proc Natl Acad Sci USA 2004;101(16):6212-6216.

57. van der Hoek L, Pyrc K, Jebbink MF, Vermeulen-Oost W, Berkhout RJM, Wolthers KC, Wertheim-van Dillen PME, Kaandorp J, Spaargaren J and Berkhout B. Identification of a new human coronavirus. Nat Med 2004;10(4):368-373.

58. Woo PC, Lau SK, Chu CM, Chan KH, Tsoi HW, Huang Y, Wong BH, Poon RW, Cai JJ, Luk WK, Poon LL, Wong SS, Guan Y, Peiris JS and Yuen KY. Characterization and complete genome sequence of a novel coronavirus, coronavirus HKU1, from patients with pneumonia. J Virol 2005;79(2):884-895.

59. Prill MM, Iwane MK, Edwards KM, Williams JV, Weinberg GA, Staat MA, Willby MJ, Talbot HK, Hall CB, Szilagyi PG, Griffin MR, Curns AT and Erdman DD; New Vaccine Surveillance Network. Human coronavirus in young children hospitalized for acute respiratory illness and asymptomatic controls. Pediatr Infect Dis J 2012;31(3):235-240.

60. Drosten C, Gunther S, Preiser W, van der Werf S, Brodt HR, Becker S, Rabenau H, Panning M, Kolesnikova L, Fouchier RAM, Berger A, Burguière AM, Cinatl J, Eickmann M, Escriou N Grywna K, Kramme S, Manuguerra JC, Müller S, Rickerts V, Stürmer M, Vieth S, Klenk HD, Osterhaus ADME, Schmitz H and Doerr HW. Identification of a novel coronavirus in patients with severe acute respiratory syndrome. N Engl J Med 2003;348(20):1967-1976.

61. Zaki AM, van BS, Bestebroer TM, Osterhaus ADME and Fouchier RAM. Isolation of a novel coronavirus from a man with pneumonia in Saudi Arabia. N Engl J Med 2012;367(19):18141820.

62. Gaynor AM, Nissen MD, Whiley DM, Mackay IM, Lambert SB, Wu G, Brennan DC, Storch GA, Sloots TP and Wang D. Identification of a novel polyomavirus from patients with acute respiratory tract infections. PLoS Pathog 2007;3(5):e64.

63. Allander T, Andreasson K, Gupta S, Bjerkner A, Bogdanovic G, Persson MA, Dalianis $T$, Ramqvist $T$ and Andersson B. Identification of a third human polyomavirus. J Virol 2007;81(8):4130-4136.

64. Mueller A, Simon A, Gillen J, Schildgen V, Tillmann RL, Reiter Kand Schildgen O. Polyomaviruses $\mathrm{KI}$ and WU in children with respiratory tract infection. Arch Virol 2009;154(10):1605-1608. 
65. Rao S, Lucero MG, Nohynek H, Tallo V, Lupisan SP, Garcea RL and Simões EAF; ARIVAC Consortium. WU and $\mathrm{KI}$ polyomavirus infections in Filipino children with lower respiratory tract disease. J Clin Virol 2016;82:112-118.

66. Sly PD and Jones CM. Viral co-detection in infants hospitalized with respiratory disease: is it important to detect? J Pediatr (Rio J ) 2011;87(4):277-280.

67. Mansbach JM, Piedra PA, Teach SJ, Sullivan AF, Forgey T, Clark S, Espinola JA and Camargo CA Jr; MARC-30 Investigators. Prospective multicenter study of viral etiology and hospital length of stay in children with severe bronchiolitis. Arch Pediatr Adolesc Med 2012;166(8):700-706.

68. Brand HK, de Groot R, Galama JM, Brouwer ML, Teuwen K, Hermans PW, Melchers WJ and Warris A. Infection with multiple viruses is not associated with increased disease severity in children with bronchiolitis. Pediatr Pulmonol 2012;47(4):393-400.

69. Martin ET, Kuypers J, Wald A and Englund JA. Multiple versus single virus respiratory infections: viral load and clinical disease severity in hospitalized children. Influenza Other Respi Viruses 2012;6(1):71-77.

70. Martinez P, Cordero J, Valverde C, Unanue N, Dalmazzo R, Piemonte P, Vergara I and Torres $J P$. Viral respiratory co-infections in pediatric patients admitted for acute respiratory infection and their impact on clinical severity. Rev Chilena Infectol 2012;29(2):169-174.

71. Ricart S, Marcos MA, Sarda M, Anton A, Muñoz-Almagro C, Pumarola T, Pons M and Garcia-Garcia JJ. Clinical risk factors are more relevant than respiratory viruses in predicting bronchiolitis severity. Pediatr Pulmonol 2012.

72. Calvo C, Garcia-Garcia ML, Blanco C, Vázquez MC, Frías ME, Pérez-Breña P and Casas I. Multiple simultaneous viral infections in infants with acute respiratory tract infections in Spain. J Clin Virol 2008;42(3):268-272.

73. Semple MG, Cowell A, Dove W, Greensill J, McNamara PS, Halfhide C, Shears P, Smyth RL and Hart CA. Dual infection of infants by human metapneumovirus and human respiratory syncytial virus is strongly associated with severe bronchiolitis. J Infect Dis 2005;191(3):382386.

74. Leber AL. Pertussis: relevant species and diagnostic update. Clin Lab Med 2014;34(2):237255.

75. Carbonetti NH. Contribution of pertussis toxin to the pathogenesis of pertussis disease. Pathog Dis 2015;73(8):ftv073.

76. de Greeff SC, de Melker HE, van Gageldonk PG, Schellekens JF, van der Klis FR, Mollema L, Mooi FR and Berbers GA. Seroprevalence of pertussis in The Netherlands: evidence for increased circulation of Bordetella pertussis. PLoS One 2010;5(12):e14183.

77. Breakwell L, Kelso P, Finley C, Schoenfeld S, Goode B, Misegades LK, Martin SW and Acosta AM. Pertussis Vaccine Effectiveness in the Setting of Pertactin-Deficient Pertussis. Pediatrics 2016;137(5).

78. Pertussis vaccines: WHO position paper, August 2015 - Recommendations. Vaccine 2016;34(12):1423-1425.

79. Dalpke A, Zimmermann S and Schnitzler P. Underdiagnosing of Mycoplasma pneumoniae infections as revealed by use of a respiratory multiplex PCR panel. Diagn Microbiol Infect Dis 2016;86(1):50-52.

80. Spuesens EB, Fraaij PLA, Visser EG, Hoogenboezem T, Hop WC, van Adrichem LN, Weber F, Moll HA, Broekman B, Berger MY, van Rijsoort-Vos T, van Belkum A, Schutten M, Pas SD, Osterhaus ADME, Hartwig NG, Vink C and van Rossum AMC. Carriage of Mycoplasma pneumoniae in the upper respiratory tract of symptomatic and asymptomatic children: an observational study. PLoS Med 2013;10(5):e1001444. 
81. Versteegh FGA, Mooi-Kokenberg EANM, Schellekens JF and Roord JJ. Bordetella pertussis and mixed infections. Minerva Pediatr 2006;58(2):131-137.

82. McCullers JA. Insights into the interaction between influenza virus and pneumococcus. Clin Microbiol Rev 2006;19(3):571-582.

83. Ayala VI, Teijaro JR, Farber DL, Dorsey SG and Carbonetti NH. Bordetella pertussis infection exacerbates influenza virus infection through pertussis toxin-mediated suppression of innate immunity. PLoS One 2011;6(4):e19016.

84. Bosch AA, Biesbroek G, Trzcinski K, Sanders EA and Bogaert D. Viral and bacterial interactions in the upper respiratory tract. PLoS Pathog 2013;9(1):e1003057.

85. Mulholland EK, Olinsky A and Shann FA. Clinical findings and severity of acute bronchiolitis. Lancet 1990;335(8700):1259-1261.

86. Lynch T, Bialy L, Kellner JD, Osmond MH, Klassen TP, Durec T, Leicht R and Johnson DW. A systematic review on the diagnosis of pediatric bacterial pneumonia: when gold is bronze. PLoS One 2010;5(8):e11989.

87. Scott JA, Wonodi C, Moisi JC, Deloria-Knoll M, DeLuca AN, Karron RA, Bhat N, Murdoch DR, Crawley J, Levine OS, O'Brien KL and Feikin DR; Pneumonia Methods Working Group. The definition of pneumonia, the assessment of severity, and clinical standardization in the Pneumonia Etiology Research for Child Health study. Clin Infect Dis 2012;54 Suppl 2:S109S116.

88. Schuh S, Lalani A, Allen U, Manson D, Babyn P, Stephens D, MacPhee S, Mokanski M, Khaikin $S$ and Dick P. Evaluation of the utility of radiography in acute bronchiolitis. J Pediatr 2007;150(4):429-433.

89. Doan Q, Enarson P, Kissoon N, Klassen TP and Johnson DW. Rapid viral diagnosis for acute febrile respiratory illness in children in the Emergency Department. Cochrane Database Syst Rev 2012;5:CD006452.

90. Byington CL, Castillo H, Gerber K, Daly JA, Brimley LA, Adams S, Christenson JC and Pavia AT. The effect of rapid respiratory viral diagnostic testing on antibiotic use in a children's hospital. Arch Pediatr Adolesc Med 2002;156(12):1230-1234.

91. Juven T, Mertsola J, Toikka P, Virkki R, Leinonen M and Ruuskanen O. Clinical profile of serologically diagnosed pneumococcal pneumonia. Pediatr Infect Dis J 2001;20(11):10281033.

92. Flood RG, Badik J and Aronoff SC. The utility of serum C-reactive protein in differentiating bacterial from nonbacterial pneumonia in children: a meta-analysis of 1230 children. Pediatr Infect Dis J 2008;27(2):95-99.

93. Dandona P, Nix D, Wilson MF, Aljada A, Love J, Assicot M and Bohuon C. Procalcitonin increase after endotoxin injection in normal subjects. J Clin Endocrinol Metab 1994;79(6):16051608.

94. van Rossum AMC, Wulkan RW and Oudesluys-Murphy AM. Procalcitonin as an early marker of infection in neonates and children. Lancet Infect Dis 2004;4(10):620-630.

95. Lowell DI, Lister G, Von KH and McCarthy P. Wheezing in infants: the response to epinephrine. Pediatrics 1987;79(6):939-945.

96. Duncan H, Hutchison J and Parshuram CS. The Pediatric Early Warning System score: a severity of illness score to predict urgent medical need in hospitalized children. J Crit Care 2006;21(3):271-278.

97. Fraser DD, Singh RN and Frewen T. The PEWS score: potential calling criteria for critical care response teams in children's hospitals. J Crit Care 2006;21(3):278-279. 
98. Parshuram CS, Hutchison J and Middaugh K. Development and initial validation of the Bedside Paediatric Early Warning System score. Crit Care 2009;13(4):R135.

99. Chalut DS, Ducharme FM and Davis GM. The Preschool Respiratory Assessment Measure (PRAM): a responsive index of acute asthma severity. J Pediatr 2000;137(6):762-768.

100. Kristjansson S, Lodrup Carlsen KC, Wennergren G, Strannegard IL and Carlsen KH. Nebulised racemic adrenaline in the treatment of acute bronchiolitis in infants and toddlers. Arch Dis Child 1993;69(6):650-654.

101. Silverman WA and Andersen DH. A controlled clinical trial of effects of water mist on obstructive respiratory signs, death rate and necropsy findings among premature infants. Pediatrics 1956;17(1):1-10.

102. Caserta MT, Qiu X, Tesini B, Wang L, Murphy A, Corbett A, Topham DJ, Falsey AR, HoldenWiltse J and Walsh EE. Development of a Global Respiratory Severity Score (GRSS) for Respiratory Syncytial Virus Infection in Infants. J Infect Dis 2017;215(5):750-756

103. Gern JE, Martin MS, Anklam KA, Shen K, Roberg KA, Carlson-Dakes KT, Adler K, Gilbertson-White S, Hamilton R, Shult PA, Kirk CJ, Da Silva DF, Sund SA, Kosorok MR and Lemanske RF Jr. Relationships among specific viral pathogens, virus-induced interleukin-8, and respiratory symptoms in infancy. Pediatr Allergy Immunol 2002;13(6):386-393.

104. Justicia-Grande AJ, Pardo-Seco J, Cebey-Lopez M, Vilanova-Trillo L, Gómez-Carballa A, Rivero-Calle I, Puente-Puig M, Curros-Novo C, Gómez-Rial J, Salas A, Martinón-Sánchez JM, Redondo-Collazo L, Rodríguez-Tenreiro C and Martinón-Torres F; Respiratory Syncytial Virus network (ReSVinet). Development and Validation of a New Clinical Scale for Infants with Acute Respiratory Infection: The ReSVinet Scale. PLoS One 2016;11(6):e0157665.

105. Bloemers BL, van Furth AM, Weijerman ME, Gemke RJ, Broers CJ, van den Ende K, Kimpen $J L$, Strengers JL and Bont LJ. Down syndrome: a novel risk factor for respiratory syncytial virus bronchiolitis-a prospective birth-cohort study. Pediatrics 2007;120(4):e1076-e1081.

106. Murray J, Bottle A, Sharland M, Modi N, Aylin P, Majeed A, Saxena S; Medicines for Neonates Investigator Group. Risk factors for hospital admission with RSV bronchiolitis in England: a population-based birth cohort study. PLoS One 2014;9(2):e89186.

107. Bradley JS, Byington CL, Shah SS, Alverson B, Carter ER, Harrison C, Kaplan SL, Mace SE, McCracken GH Jr, Moore MR, St Peter SD, Stockwell JA and Swanson JT; Pediatric Infectious Diseases Society and the Infectious Diseases Society of America. The management of community-acquired pneumonia in infants and children older than 3 months of age: clinical practice guidelines by the Pediatric Infectious Diseases Society and the Infectious Diseases Society of America. Clin Infect Dis 2011;53(7):e25-e76.

108. American Academy of Pediatrics Subcommittee on Diagnosis and Management of Bronchiolitis. Diagnosis and management of bronchiolitis. Pediatrics 2006;118:17741793.

109. Zorc JJ and Hall CB. Bronchiolitis: recent evidence on diagnosis and management. Pediatrics 2010;125(2):342-349.

110. Parikh K, Hall M and Teach SJ. Bronchiolitis management before and after the AAP guidelines. Pediatrics 2014;133(1):e1-e7.

111. Sharland M. Lower respiratory tract infection. In: Sharland M, editor. Manual of Childhood Infections, The Blue Book. Oxford University Press; 2011:230-239.

112. Feikin DR, Njenga MK, Bigogo G, Aura B, Gikunju S, Balish A, Katz MA, Erdman D and Breiman RF. Additional diagnostic yield of adding serology to PCR in diagnosing viral acute respiratory infections in Kenyan patients 5 years of age and older. Clin Vaccine Immunol 2013;20(1):113-114. 
113. Freymuth F, Vabret A, Cuvillon-Nimal D, Simon S, Dina J, Legrand L, Gouarin S, Petitjean J, Eckart $P$ and Brouard J. Comparison of multiplex PCR assays and conventional techniques for the diagnostic of respiratory virus infections in children admitted to hospital with an acute respiratory illness. J Med Virol 2006;78(11):1498-1504.

114. leven M. Currently used nucleic acid amplification tests for the detection of viruses and atypicals in acute respiratory infections. J Clin Virol 2007;40(4):259-276.

115. Aslanzadeh J, Zheng X, Li H, Tetreault J, Ratkiewicz I, Meng S, Hamilton P and Tang YW. Prospective evaluation of rapid antigen tests for diagnosis of respiratory syncytial virus and human metapneumovirus infections. J Clin Microbiol 2008;46(5):1682-1685.

116. Ndegwa LK, Emukule G, Uyeki TM, Mailu E, Chaves SS, Widdowson MA, Lewa BV, Muiruri FK, Omoth P, Fields B and Mott JA. Evaluation of the point-of-care Becton Dickinson Veritor Rapid influenza diagnostic test in Kenya, 2013-2014. BMC Infect Dis 2017;17(1):60.

117. Schauer U, Ihorst G, Rohwedder A, Petersen G, Berner R, Frank HD, Forster J and Stephan $\mathrm{V}$. Evaluation of respiratory syncytial virus detection by rapid antigen tests in childhood. Klin Padiatr 2007;219(4):212-216.

118. Selvarangan R, Abel D and Hamilton M. Comparison of BD Directigen EZ RSV and Binax NOW RSV tests for rapid detection of respiratory syncytial virus from nasopharyngeal aspirates in a pediatric population. Diagn Microbiol Infect Dis 2008;62(2):157-161.

119. Barenfanger J, Drake C, Leon N, Mueller T and Troutt T. Clinical and financial benefits of rapid detection of respiratory viruses: an outcomes study. J Clin Microbiol 2000;38(8):28242828.

120. Doan QH, Kissoon N, Dobson S, Whitehouse S, Cochrane D, Schmidt B and Thomas E. A randomized, controlled trial of the impact of early and rapid diagnosis of viral infections in children brought to an emergency department with febrile respiratory tract illnesses. J Pediatr 2009;154(1):91-95.

121. Woo PCY, Chiu SS, Seto WH and Peiris M. Cost-effectiveness of rapid diagnosis of viral respiratory tract infections in pediatric patients. J Clin Microbiol 1997;35(6):1579-1581.

122. Jartti T, Soderlund-Venermo M, Hedman K, Ruuskanen $O$ and Makela MJ. New molecular virus detection methods and their clinical value in lower respiratory tract infections in children. Paediatr Respir Rev 2013;14(1):38-45.

123. Vallieres $E$ and Renaud C. Clinical and economical impact of multiplex respiratory virus assays. Diagn Microbiol Infect Dis 2013;76(3):255-261.

124. DeVincenzo JP, Wilkinson T, Vaishnaw A, Cehelsky J, Meyers R, Nochur S, Harrison L, Meeking P, Mann A, Moane E, Oxford J, Pareek R, Moore R, Walsh E, Studholme R, Dorsett $P$, Alvarez $R$ and Lambkin-Williams $R$. Viral load drives disease in humans experimentally infected with respiratory syncytial virus. Am J Respir Crit Care Med 2010;182(10):13051314.

125. Houben ML, Coenjaerts FE, Rossen JW, Belderbos ME, Hofland RW, Kimpen JL and Bont LJ. Disease severity and viral load are correlated in infants with primary respiratory syncytial virus infection in the community. J Med Virol 2010;82(7):1266-1271.

126. Van Leeuwen JC, Goossens LK, Hendrix RM, Van Der Palen J, Lusthusz A and Thio BJ. Equal virulence of rhinovirus and respiratory syncytial virus in infants hospitalized for lower respiratory tract infection. Pediatr Infect Dis J 2012;31(1):84-86.

127. Fodha I, Vabret A, Ghedira L, Seboui H, Chouchane S, Dewar J, Gueddiche N, Trabelsi A, Boujaafar N and Freymuth F. Respiratory syncytial virus infections in hospitalized infants: association between viral load, virus subgroup, and disease severity. J Med Virol 2007;79(12):1951-1958. 
128. Franz A, Adams O, Willems R, Bonzel L, Neuhausen N, Schweizer-Krantz S, Ruggeberg JU, Willers $\mathrm{R}$, Henrich B, Schroten $\mathrm{H}$ and Tenenbaum T. Correlation of viral load of respiratory pathogens and co-infections with disease severity in children hospitalized for lower respiratory tract infection. J Clin Virol 2010;48(4):239-245.

129. Gerna G, Sarasini A, Percivalle E, Campanini G, Rovida F, Marchi A and Baldanti F. Prospective study of human metapneumovirus infection: diagnosis, typing and virus quantification in nasopharyngeal secretions from pediatric patients. J Clin Virol 2007;40(3):236-240.

130. Jansen RR, Schinkel J, Dek I, Koekkoek SM, Visser CE, de Jong MD, Molenkamp R and Pajkrt D. Quantitation of respiratory viruses in relation to clinical course in children with acute respiratory tract infections. Pediatr Infect Dis J 2010;29(1):82-84.

131. Wright PF, Gruber WC, Peters $M$, Reed G, Zhu Y, Robinson F, Coleman-Dockery $S$ and Graham BS. Illness severity, viral shedding, and antibody responses in infants hospitalized with bronchiolitis caused by respiratory syncytial virus. J Infect Dis 2002;185(8):1011-1018.

132. Stocker M, van Herk W, El Helou S, Dutta S, Fontana MS, Schuerman FABA, van den Toorende Groot RK, Wieringa JW, Janota J, van der Meer-Kappelle LH, Moonen R, Sie SD, de Vries E, Donker AE, Zimmerman U, Schlapbach LJ, de Mol AC, Hoffman-Haringsma A, Roy M, Tomaske M, Kornelisse RF, van Gijsel J, Visser EG, Willemsen SP, van Rossum AMC; NeoPInS Study Group. Procalcitonin-guided decision making for duration of antibiotic therapy in neonates with suspected early-onset sepsis: a multicentre, randomised controlled trial (NeoPIns). Lancet. 2017 Aug 26;390(10097):871-881. 


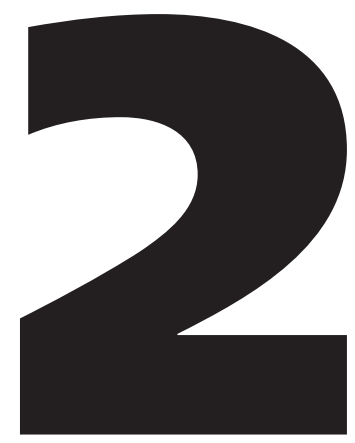




\section{CLINICAL IMPACT OF RT-PCR FOR PEDIATRIC}

ACUTE RESPIRATORY INFECTIONS: A CONTROLLED CLINICAL TRIAL

Jérôme O. Wishaupt, Anne Russcher, Leo C. Smeets, Florens G. A. Versteegh and Nico G. Hartwig 


\section{ABSTRACT \\ Objective}

Real-time polymerase chain reaction (RT-PCR) testing is a quick sensitive method for detecting respiratory pathogens. We evaluated the diagnostic yield of RT-PCR assays and measured the effect of rapid reporting on patient care.

\section{Methods}

In a controlled clinical trial, nasal wash specimens were obtained from patients $<12$ years of age with suspected acute respiratory infections. In addition to the standard hospital protocol, RT-PCR assays for 17 pathogens were performed. The RT-PCR results were communicated to the clinicians within 12 to 36 hours in the intervention group and after 4 weeks in the control group.

\section{Results}

A total of 583 patients were included (mean age: 8.1 months [range: $0-107.5$ months]): 298 in the intervention group and 285 in the control group. Eighty-two percent of nasal wash specimens tested positive for $\geq 1$ pathogen. Respiratory syncytial virus was the most frequently encountered (55\%) pathogen. There were no significant differences between the groups with respect to hospital admissions (intervention group: 223 admissions; control group: 211 admissions; $P=.825$ ), length of hospital stay (mean \pm SD: $3.68 \pm 2.68$ days [intervention group] and $3.96 \pm 2.67$ days [control group]; $P=.178$ ), or duration of antibiotic use (mean \pm SD: $6.52 \pm 2.15$ days [intervention group] and $6.97 \pm 2.86$ days [control group]; $P=.490$ ), when antibiotic treatment had been initiated.

\section{Conclusions}

RT-PCR testing has a high yield of viral diagnoses, but rapid communication does not lead to decreases in hospital admissions, shorter hospital stays, or less antibiotic use for children with acute respiratory infections.

\section{Key words}

polymerase chain reaction, respiratory infections, child, patient care, controlled clinical trial 


\section{INTRODUCTION}

In developed countries, acute respiratory infection (ARI) is a leading cause of hospitalization for young children. ${ }^{1}$ ARIs also are responsible for high levels of antibiotic consumption by children, although most ARIs are viral in origin. 2,3 Unnecessary antibiotic prescriptions for viral illnesses contribute to antibiotic resistance in the population and lead to greater health expenses.

Until recently, viral culture, direct fluorescent assays (DFAs), and rapid antigen detection have been used as standard diagnostic procedures to identify possible viral pathogens. Unfortunately, these techniques have several limitations. Viral culture requires specialized laboratory facilities. It is a time-consuming procedure, and results often are available too late to influence patient care. DFA provides results more rapidly but is less sensitive than viral culture. DFA is a suitable diagnostic test for only a few viruses. ${ }^{4,5}$ Rapid antigen detection tests are available for respiratory syncytial virus (RSV) and influenza virus, but their sensitivity ranges from $66.2 \%$ to $94.1 \%{ }^{6-8}$ Multiple real-time polymerase chain reaction (RT-PCR) formats have been introduced as a substitute for conventional techniques. RT-PCR testing has made it possible to identify many causative agents within a short period of 6 to 24 hours and has been shown to be more sensitive than viral culture. ${ }^{4}$

Several studies with pediatric populations have shown that rapid viral detection (eg, DFAs and rapid antigen detection) contributes to changes in patient care, most importantly reductions in hospital stays and antibiotic use. ${ }^{9-12}$ Similar results might be expected with RT-PCR testing, although this assumption is not yet supported by literature findings.

Many hospitals have introduced RT-PCR assays for the detection of viral pathogens among children with ARIs, leading to increased diagnostic expenses, ${ }^{13}$ but cost reduction in patient care has not been studied in depth. A study of the impact of polymerase chain reaction (PCR) assays of respiratory samples did not find reductions in antibiotic use or costs. ${ }^{13}$ However, that study was conducted with an adult population, which differs from pediatric populations in epidemiological and etiologic features. In a prospective study on antibiotic prescriptions for a PICU population (38 children undergoing ventilation), RT-PCR results did not alter antibiotic prescription habits at all; in a paper case study, however, physicians stated that RT-PCR results would reduce their antibiotic prescriptions. ${ }^{14}$ This study was performed to evaluate (1) the diagnostic yield of RT-PCR assays for children with ARI symptoms in a general pediatric setting and (2) the effects on patient care, measured on the basis of hospital stays and antibiotic use, of rapid communication of the results to physicians. 


\section{METHODS \\ Study Design}

This study was part of the Evaluation of Viral Diagnostics on Respiratory Infections in Children trial, which was designed as a multicenter, controlled, clinical trial to evaluate viral RT-PCR diagnostic methods for ARIs in pediatric patients. The trial was conducted during 2 consecutive winter seasons at Reinier de Graaf Hospital (Delft, Netherlands), which was joined in the second season by the Groene Hart Ziekenhuis (Gouda, Netherlands). Reinier de Graaf Hospital is a 900-bed community hospital, and Groene Hart Ziekenhuis is a 550-bed community hospital. Both serve as university teaching hospitals. The Evaluation of Viral Diagnostics on Respiratory Infections in Children trial protocol was approved by the regional medical ethics committee. From November 1, 2007, to May 7, 2008, and from October 1, 2008, to March 31, 2009, nasal wash specimens (NWSs) were obtained from children who were admitted to the emergency department (ED) or pediatric outpatient department with suspected ARIs.

For all patients, standard testing according to the hospital protocol was performed; this testing included DFAs for RSV, influenza A and B, adenovirus, and parainfluenza viruses 1,2 , and 3 and viral culture. In addition to the standard protocol, RT-PCR was performed for 15 viruses and 2 bacteria (RSV A, RSV B, influenza viruses $A$ and $B$, adenovirus, parainfluenza viruses $1,2,3$, and 4 , human bocavirus, coronaviruses 229E, OC43, and NL63, human metapneumovirus, rhinovirus, Chla- mydophila pneumoniae, and Mycoplasma pneumoniae), as well as Bordetella pertussis. For patients in the intervention group, positive RT-PCR assay results were communicated to the attending clinician the following day. For patients in the control group, RT-PCR assay results were communicated to the attending clinician after 4 weeks.

Informed consent for study participation was sought after the NWS was obtained, because nasal washings are part of standard diagnostic procedures. Randomization took place in the laboratory. At arrival in the laboratory, samples were assigned an order number. Samples with even order numbers were assigned to the intervention group, whereas samples with odd order numbers were assigned to the control group. Assignment of order numbers was a computerized procedure and occurred independently of clinical evaluation of the patients. Blinding of clinicians to the intervention was not possible because of the nature of the diagnostic intervention. Preliminary power analysis indicated that $2 \times 277$ patients would be required to prove a difference in the length of hospital stay of 1 day with $80 \%$ power, on the basis of a mean length of hospital stay of 5.4 days (SD:4.2 days) for RSV infections. ${ }^{15}$

\section{Inclusion and Exclusion Criteria}

Patients $<12$ years of age were eligible when a NWS was obtained because of a suspected ARI. NWSs were obtained from all children $<2$ months of age with signs of ARIs, following the Dutch recommendation to detect RSV in young children at risk 
for apnea. For children $>2$ months of age, NWSs were obtained when the patients showed signs of respiratory distress such as tachypnea (age-dependent cutoff values), dyspnea (nose flaring or retractions), or hypoxia (pulse oximetric peripheral oxygen saturation of $<92 \%$ ). Exclusion criteria were underlying anatomic airway abnormalities (eg, bronchopulmonary dysplasia or laryngomalacia) or other significant underlying disorders (syndromal disorders that included psychomotor retardation, malignancies, or cardiac pathologic conditions). Also excluded were all newborns who had been hospitalized since birth. Patients with asthma or suspected asthma could be included.

Patients could be included in the trial multiple times during the 2 seasons but only once during a clinical episode of illness. To ensure this, patients were included for a second time only if the dates of NWS sampling were $\geq 14$ days apart. In addition, patient data were reviewed to ensure that the samples were obtained in clinically different episodes.

\section{Samples}

Duplex RT-PCR assays were performed with all NWSs. Nucleic acid extraction was performed after addition of an internal control (RNA viruses: phocine distemper virus; DNA viruses: artificial plasmid). Nucleic acid extractions were performed with an Xtractor gene nucleic acid extraction robot (Qiagen, Hilden, Germany) with an Invisorb virus RNA HTS 96 kit (Invitek, Berlin, Germany) and a Corbett DX DNA extraction kit (Qiagen), according to standard procedures recommended by the suppliers. For RNA viruses, a random-primed reverse transcription reaction was performed with $57 \mu \mathrm{L}$ of RNA (Mul- tiScribe RT [Applied Biosystems, Carlsbad, CA]). RT-PCR was performed on the copy DNA obtained in this way, with an AB17500 thermocycler (Applied Bio- systems), by using an in-house assay adapted from the Erasmus Medical Center (courtesy of Dr M. Schutten, Erasmus Medical Center, Rotterdam, Netherlands). Each reaction tube was internally controlled. The validation procedure for RT-PCR assays for all targets is presented in the Appendix.

\section{Data Collection}

Clinical data were obtained by using a standardized form, which was completed prospectively for each patient by the attending clinician. The form was developed in a pilot study between November 2006 and April 2007. A standard form for collecting clinical data on respiratory symptoms was not available in the existing literature. Data included demographic characteristics, presenting symptoms in the history and from the physical examination, diagnoses at admission and at discharge, length of hospital stay, duration of antibiotic use and type of antibiotic prescribed (if applicable), and the need for and duration of supplemental oxygen treatment, inhalation steroid therapy, bronchodilator administration, and tube feeding. Missing information was retrieved from the patient's medical record. Laboratory and radiologic reports were retrieved from the hospital's records. 


\section{Definitions}

ARI was defined as a new episode of respiratory symptoms of the upper and/or lower airways. Upper respiratory tract infection (URTI) was defined as respiratory symptoms without abnormalities on lung auscultation (eg, rhinorrhea, nasal congestion, sore throat, erythematous pharynx, earache, or erythematous eardrum). Lower respiratory tract infection (LRTI) was defined as respiratory symptoms with abnormalities on lung auscultation (eg, rales, crackles, crepitations, wheezing, or prolonged expiration). For this study, bacterial pneumonia was defined as confirmed infiltrate on chest radiographs or as the presence of $\geq 3$ of the following; focal signs on lung auscultation, fever of $>39.0^{\circ} \mathrm{C}$, hypoxia, increased work of breathing (tachypnea and/ or dyspnea), or C-reactive protein (CRP) level of $>40 \mathrm{mg} / \mathrm{L}$. This CRP cutoff value was based on a meta-analysis by Flood et $\mathrm{al}^{1{ }^{16}}$ who showed in a pooled study population of 1230 patients a correlation of CRP levels with bacterial pneumonia. CRP cutoff values of 40 to $60 \mathrm{mg} / \mathrm{L}$ show a positive predictive value of $64 \% .{ }^{16}$ Bronchiolitis was defined as the presence of bilateral wheezing and/ or crackles in combination with increased work of breathing or hypoxia. Bronchial hyperreactivity was defined as cough or wheezing in combination with increased work of breathing that responded well to bronchodilator therapy.

\section{Statistical Analyses}

Statistical analyses were performed by using SPSS 18.0 (SPSS, Chicago, IL). All analyses were performed on an intention-to-treat basis. The intervention group and control group were compared for equality by using Mann-Whitney $U$ tests for variables with skewed distributions and y2 tests for categorical variables. Comparisons between outcomes in the 2 groups were made by using Mann-Whitney $U$ tests for skewed variables and $\chi 2$ tests for categorical variables. Significance was determined at $\alpha<.05$.

Multivariate regression analysis was used to analyze the relationships between outcome (length of hospital stay) and infection groups and therapy variables. For the multivariate analysis, we included variables with univariate $P$ values of $<.20$ and variables with correlation coefficient Spearman's $\rho$ values of $>0.5$.

\section{RESULTS}

\section{Patient Enrollment}

During the 2-winter study period, a total of 776 NWSs were analyzed by the laboratory. Of those, 614 met the inclusion criteria. Thirty-one cases could not be analyzed because of missing clinical data or loss to follow-up monitoring, mostly in cases of relocation to another hospital. In total, 583 NWSs were enrolled in this study. Of these, 298 were assigned randomly to the intervention group, and 285 were assigned randomly to the control group. Figure 1 shows the flowchart of patient enrollment. 


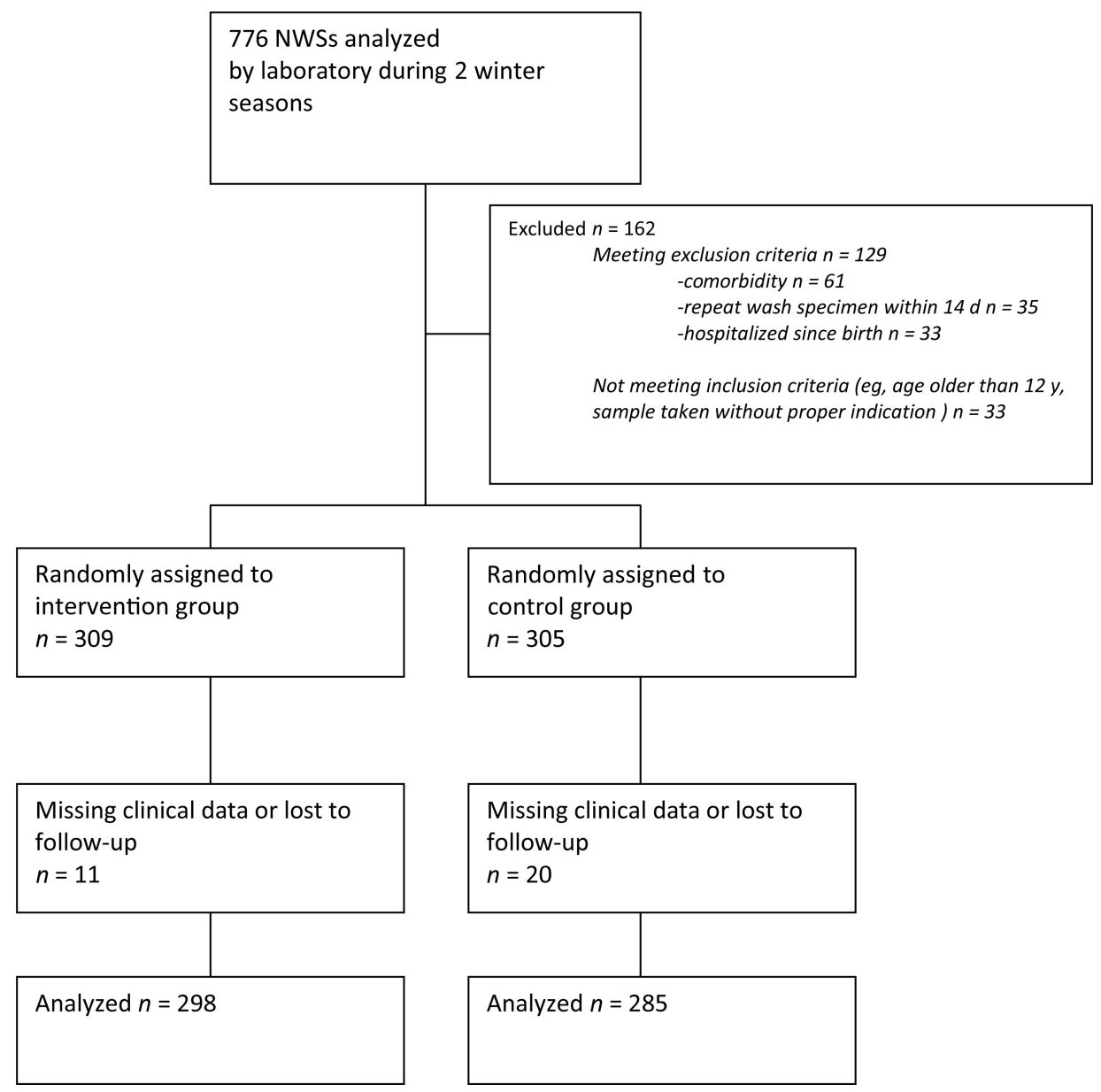

Figure 1. Flowchart of patient enrollment.

\section{Patient Characteristics}

Demographic and clinical characteristics are presented in Table 1. The groups were comparable with regard to age, gender, diagnosis, and presence of bronchial hyperreactivity.

\section{Outcomes}

Table 2 shows the results of RT-PCR sorted according to the presence of exclusively URTI or URTI in combination with LRTI (URTI/LRTI). Only 3 patients had a diagnosis of exclusively LRTIs (2 patients had bacterial pneumonia and 1 patient had tuberculosis) without URTI; consequently, their NWSs tested negative (data not shown in Table 2). Seven of 9 patients with whooping cough also had positive RT-PCR results for Š 1 virus, and results for those 9 patients are included in Table 2. 
Table 1. Demographic and Clinical Characteristics of Patients

\begin{tabular}{lllr}
\hline & $\begin{array}{l}\text { Intervention } \\
\text { Group }\end{array}$ & Control Group & $\boldsymbol{P}$ \\
\hline $\mathrm{N}$ & 298 & 285 & \\
Age, mo & & & \\
$\quad$ Mean (range) & $8.2(0-107.5)$ & $8.1(0-89.4)$ & $.877^{\mathrm{a}}$ \\
$\quad$ Median & 4.0 & 4.3 & \\
Male, $n$ (\%) & $165(55)$ & $171(60)$ & $.258^{\mathrm{b}}$ \\
Inclusion in Reinier de Graaf Hospital, $n$ (\%) & $200(67.1)$ & $203(71.2)$ & $.282^{\mathrm{b}}$ \\
Inclusion in Groene Hart Ziekenhuis, $n$ (\%) & $98(32.9)$ & $82(28.8)$ & \\
Clinical diagnosis, $n$ (\%) & & & \\
$\quad$ Exclusively URTI & $165(55.4)$ & $158(55.4)$ & $.864^{\mathrm{b}}$ \\
$\quad$ Exclusively LRTI & $2(0.7)$ & $1(0.4)$ & $\mathrm{c}$ \\
$\quad$ Combined URTI and LRTI & $120(40.3)$ & $112(39.3)$ & $.762^{\mathrm{b}}$ \\
$\quad$ Exclusively bronchiolitis & $64(53.3)$ & $67(59.8)$ & $.840^{\mathrm{b}}$ \\
$\quad$ Exclusively pneumonia & $35(29.2)$ & $33(29.5)$ & $.840^{\mathrm{b}}$ \\
$\quad$ Both bronchiolitis and pneumonia & $19(15.8)$ & $10(8.9)$ & $.275^{\mathrm{b}}$ \\
$\quad$ Whooping cough & $5(1.7)$ & $4(1.4)$ & ${ }^{c}$ \\
$\quad$ No respiratory diagnosis & $11(3.7)$ & $14(4.9)$ & $.762^{\mathrm{b}}$ \\
CRP assay performed, $n$ (\%) & $168(56.4)$ & $142(49.8)$ & $.113^{\mathrm{b}}$ \\
CRP level, mean (range), mg/L ${ }^{\mathrm{d}}$ & $40(1-359)$ & $31(1-330)$ & $.694^{\mathrm{a}}$ \\
CRP level of $>40$ mg/L, $n / N$ (\%) & $40 / 168(23.8)$ & $23 / 142(16.2)$ & $.097^{\mathrm{b}}$ \\
Chest radiography performed, $n$ (\%) & $150(50.3)$ & $124(43.5)$ & $.099^{\mathrm{b}}$ \\
\hline
\end{tabular}

a For continuous variables, Mann-Whitney $U$ tests were used.

b For categorical variables, $y^{2}$ tests were used

c Not applicable; frequencies were too low.

d Normal value: $<1 \mathrm{mg} / \mathrm{L}$.

In 477 (82\%) of 583 NWSs, $\geq 1$ pathogen was identified. Patients with combined URTIs and LRTIs had more positive RT- PCR results than did patients with exclusively URTIs. Two viral agents were found in $114(20 \%)$ of 583 NWSs. Multiple infections with $3(n=23[4 \%])$ or $4(n=3[0.5 \%])$ viruses also occurred. Dual infections were equally distributed among patients with exclusively URTIs and those with combined URTIs and LRTIs; triple and quadruple infections were encountered more frequently among patients with combined URTIs and LRTIs. For both URTIs and URTIS/LRTIS, RSV was the most prominent pathogen (identified in 55\% of NWSs), followed by rhinovirus, coronaviruses, adenovirus, and human metapneumovirus (identified in $~ 8 \%$ to $14 \%$ of NWSs). Influenza and parainfluenza viruses were identified in $\sim 6 \%$ of NWSs. Human bocavirus was the least often encountered viral agent (5\%). Bacteria such as B pertussis, $M$ pneumoniae, and C pneumoniae were identified sporadically (1\%-2\%).

With regard to the main objectives of this study, there was a trend toward a shorter length of hospital stay in the intervention group, but the difference was not statistically significant. Antibiotic treatment was started significantly more often 


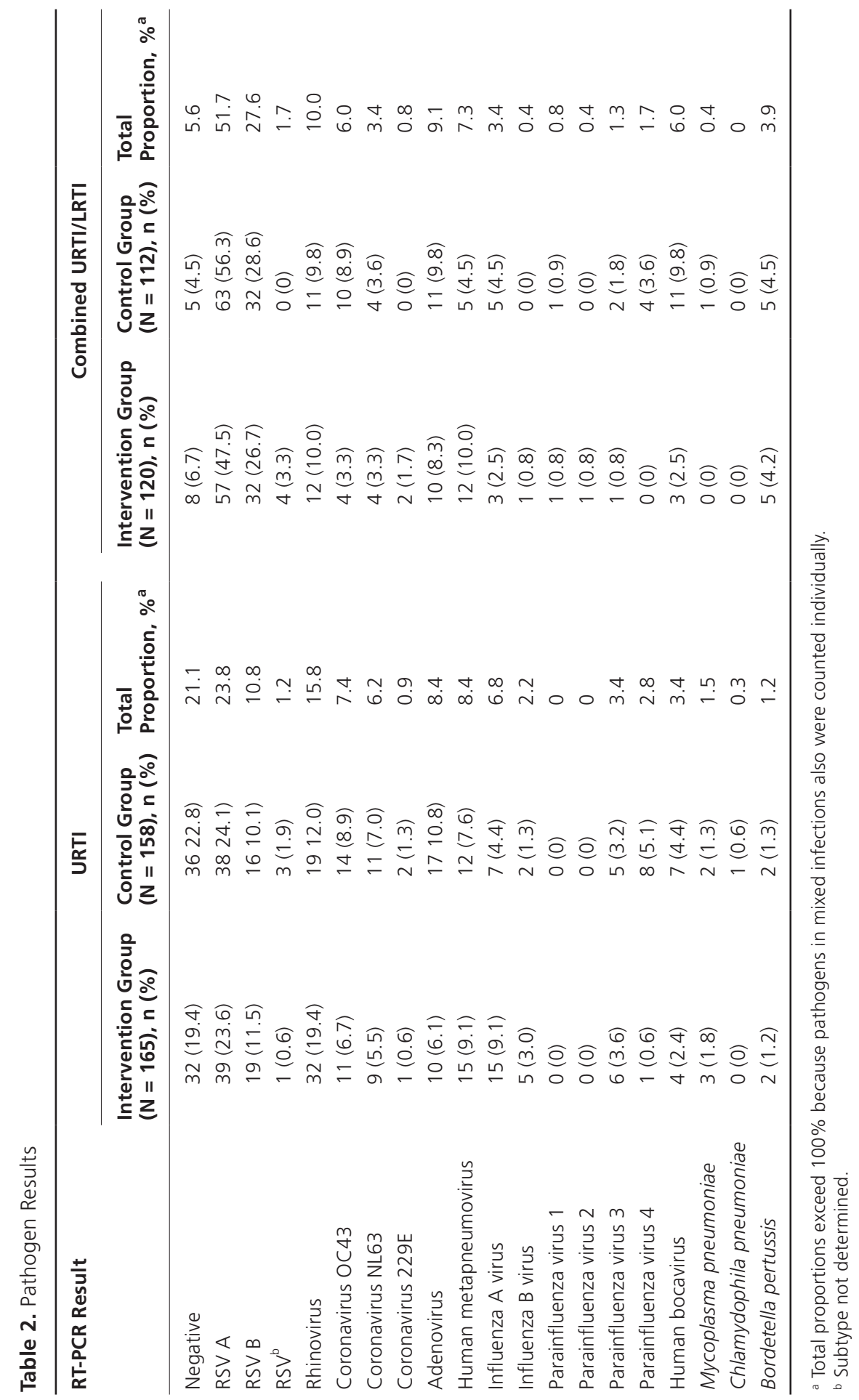


in the intervention group, but mean durations of antibiotic treatment, if antibiotic treatment was started, did not differ significantly between the groups. These results are summarized in Table 3.

For univariate and multivariate analyses, it was necessary to group viruses together (eg, RSV A and RSV B as group RSV). Univariate analyses revealed that the length of hospital stay was directly correlated with RSV infection and supplemental oxygen therapy, and there was a tendency for nebulization therapy. In a multivariate analysis, there were associations between longer hospital stays and oxygen and nebulization therapy, irrespective of the viral pathogen. Coronavirus was the viral group that showed the greatest tendency toward longer hospital stays. A summary is given in Table 4.

Table 3. Clinical Outcome Parameters

\begin{tabular}{llll}
\hline & $\begin{array}{l}\text { Intervention Group } \\
(\mathbf{N = 2 9 8 )}\end{array}$ & $\begin{array}{l}\text { Control Group } \\
(\boldsymbol{N}=\mathbf{2 8 5})\end{array}$ & $\boldsymbol{P}$ \\
\hline Hospital admissions, $n(\%)$ & $223(74.8)$ & $211(74)$ & $.825^{\text {a }}$ \\
Time in hospital, mean \pm SD (range), days & $3.68 \pm 2.68(1-18)$ & $3.96 \pm 2.67(1-15)$ & $.170^{\text {b }}$ \\
Antibody therapy initiated, $n(\%)$ & $124(41.6)$ & $78(27.4)$ & $.000^{\text {a }}$ \\
$\begin{array}{l}\text { Duration of antibody therapy if initiated, } \\
\text { mean } \pm \text { SD (range), days }\end{array}$ & $6.52 \pm 2.15(1-14)$ & $6.97 \pm 2.86(2-21)$ & $.490^{\text {b }}$ \\
\hline
\end{tabular}

a For categorical variables, y2 tests were used.

${ }^{b}$ For continuous variables, Mann-Whitney $U$ tests were used.

Table 4. Correlations Between Length of Hospital Stay and Pathogen Groups, Time With Extra Oxygen or Nebulization Therapy, and Intravenous Antibiotic Use

\begin{tabular}{lcccc}
\hline Variable & \multicolumn{2}{c}{ Univariate } & $\begin{array}{l}\text { Multivariate } \\
\text { Regression } \\
\text { Coefficient }\end{array}$ & Adjusted $\boldsymbol{P}$ \\
\cline { 2 - 4 } & $\boldsymbol{P}^{\mathbf{a}}$ & Spearman's $\boldsymbol{p}$ & 0.180 & .379 \\
\hline RSV $(n=270)$ & $<.01$ & - & 0.298 & .425 \\
Rhinovirus $(n=41)$ & .153 & - & 0.556 & .197 \\
Coronavirus $(n=42)$ & .083 & - & -0.230 & .619 \\
Adenovirus $(n=23)$ & .119 & - & - & - \\
Human metapneumovirus $(n=37)$ & .291 & - & 0.108 & .790 \\
Influenza virus $(n=32)$ & .135 & - & - & - \\
Parainfluenza virus $(n=9)$ & .322 & - & - & - \\
Human bocavirus $(n=14)$ & .379 & - & 0.775 & $<.01$ \\
Duration of oxygen treatment & - & 0.620 & 0.244 & - \\
Duration of nebulizer treatment & - & 0.259 & - & - \\
Intravenous amoxicillin treatment & - & 0.143 & - & - \\
Intravenous cephalosporin treatment & - & 0.115 & - & \\
\hline
\end{tabular}

a For continuous variables, Mann-Whitney $U$ tests were used. 


\section{DISCUSSION}

To our knowledge, this study is the first controlled clinical trial with a large general pediatric population that evaluates the clinical consequences of the introduction of RT-PCR assays into clinical practice. Other studies described the impact of rapid viral diagnosis on patient care, but they compared DFA with viral culture in an era when PCR techniques were not yet widely available. ${ }^{9-12}$ Current research on the introduction of RT-PCR assays into clinical practice has been limited to a descriptive specification of the diagnostic yield of RT-PCR assays and has not taken into account the consequences of RT-PCR diagnostic results. ${ }^{17-22}$

Although a positive viral diagnosis could be established for many patients, the numbers of hospital admissions and the lengths of hospital stays did not differ between the groups. The need for hospitalization depends primarily on clinical parameters, such as the degree of clinical illness, the need for supplemental oxygen therapy, and the need for bronchodilator nebulization therapy, rather than a confirmed viral diagnosis. This assumption is supported by the significant correlation between the length of hospital stay and the duration of supplemental oxygen or nebulization therapy. The causal direction of this relationship is obvious from a clinical perspective.

Other studies investigating the effects of rapid viral diagnosis on patient care found shortened hospital stays, but DFA was compared with viral culture in those investigations. ${ }^{10-12}$ The time lapse between the results of DFA and those of viral culture is considerably greater than the time lapse between RT-PCR and DFA results. Therefore, it might be expected that the impact of DFA results would be greater in a setting where formerly only viral culture was available. In addition, those studies were not randomized but used historical control data. Comparison was made only for patients with positive viral diagnoses, which might have lead to an optimistic estimate of the impact of viral testing. Oosterheert et al, ${ }^{13}$ who investigated the clinical consequences of viral RT-PCR diagnostic results in a randomized controlled trial involving adults, found results similar to those in our study.

The duration of antibiotic treatment was not significantly influenced by RT-PCR testing. This is partly explained by physicians' concerns regarding bacterial superinfection in patients with ARIs. Unfortunately, positive RT-PCR results do not exclude the possibility of bacterial superinfection; therefore, physicians are unlikely to change the antibiotic treatment that has been initiated. In addition, viral infection was reported previously to predispose patients to bacterial superinfection. ${ }^{23,24}$ In our study, the majority of patients with proven bacterial pneumonia also had positive RT-PCR results for a virus. Studies by Byington et $\mathrm{a}^{10}$ and Woo et $\mathrm{al}^{11}$ did find reductions in antibiotic prescriptions, but those studies evaluated DFA testing and did not have a randomized controlled design. Doan et al ${ }^{9}$ performed a randomized controlled trial that investigated rapid viral testing in relation to antibiotic prescriptions in an ED. They found no reduction in antibiotic prescriptions in primary visits to the ED, but they did 
find reductions if patients returned to the ED or to a different primary care provider; the patients with earlier viral diagnoses were prescribed antibiotics less often. ${ }^{9}$ Oosterheert et al ${ }^{13}$ failed to find a reduction in antibiotic use and doubted the effect of rapid RT-PCR results on patient care. In a small PICU population, van de Pol et al ${ }^{14}$ also did not find a difference in antibiotic prescriptions after implementation of RTPCR testing.

We have no satisfying explanation for why antibiotic treatment was started significantly more often in the intervention group. It was not expected that initiation of antibiotic treatment would be influenced by the RT-PCR results, because these results become available 12 to 24 hours after clinical evaluation. The decision to start antibiotic treatment usually is made immediately after clinical evaluation. Therefore, discontinuation of antibiotic courses was expected to occur after positive RT-PCR results were communicated to the clinicians. Several factors might have influenced the start of antibiotic treatment. In the intervention group, CRP testing was performed more often and CRP levels were slightly higher. The numbers of radiographically confirmed pneumonia diagnoses did not differ, but the number of chest radiographs was higher. This might indicate that clinical concern regarding pneumonia, although it was not radiographically confirmed, was a factor in the initiation of antibiotic treatment. We cannot exclude the possibility that decisions regarding the initiation of antibiotic treatment were made on the basis of the vaccination status of the child. However, $97 \%$ of children in our region follow the Dutch vaccination program.

This study focused on ARIs in children without significant medical history. Patients with significant underlying pathologic conditions were excluded from the study, because such patients might have comorbidities that would bias the results. However, RT-PCR testing also is a valuable tool for children with underlying conditions, for whom antibiotic treatment often is initiated more readily than for formerly healthy children.

On the basis of the results of this study, we may argue that it is not clinically relevant to perform RT-PCR testing for all respiratory viruses for every patient presenting with ARI. Because RT-PCR testing showed superior sensitivity and specificity, compared with DFA, we advise reevaluating the use of DFA in relation to RT-PCR testing, rather than excluding RT-PCR testing in daily clinical practice. A thorough cost analysis in the near future should give more clarity regarding whether RT-PCR testing for a selection of viruses could be more advantageous for patient care than the use of DFA.

\section{CONCLUSIONS}

The introduction of RT-PCR testing into general clinical practice yields many viral diagnoses but does not have a significant influence on patient care. The length of stay in the hospital and the duration of antibiotic treatment are not affected by rapid communication of the RT-PCR results. However, RT-PCR testing does have advantages 
over other diagnostic methods, such as DFA. Logistic arguments and balancing of costs should help determine whether to adopt RT-PCR testing as the new standard for viral testing for children with ARIs. The influence of RT-PCR results on clinical management for children with significant underlying pathologic conditions should be analyzed separately.

\section{APPENDIX}

The validation method for RT-PCR procedures for all targets included (1) nucleotide Basic Local Alignment Search Tool search of primer and probe sequences in the National Center for Biotechnology Information sequence database, (2) subsequent check on lack of mutations with a significant impact on RT-PCR amplification, ${ }^{25}$ (3) RT-PCR efficiency of $>90 \%$ for selected virus stocks, (4) lack of cross-reactivity with other respiratory pathogens, (5) estimated lower limit of detection of $<500$ virus particles per $\mathrm{mL}$, on the basis of RT-PCR efficiency and proper detection of virus dilutions with threshold cycle values of $>32$, and (6) for all RT-PCR procedures, $\geq 10$ samples for the less common and/or difficult-to-culture viruses (coronaviruses, rhinovirus, and parainfluenza viruses $1-4$ ) and $\geq 400$ samples for viruses that can be detected more easily by using culture and/or DFA (influenza A/B, RSV A/B, human metapneumovirus, and adenovirus) were checked for reactivity in RT-PCR.

\section{ACKNOWLEDGMENTS}

This study was financially supported by the Research Activity Committee of the Reinier de Graaf Hospital (project 620604). We thank Perry van Wunnik, who did an excellent job implementing the RT-PCR assays and the study protocol in the laboratory. We thank Marjon van Merriënboer and Ria van Leeuwen for careful and dedicated logistics and datamanagement and Tjeerd van der Ploeg for input in statistics. 


\section{REFERENCES}

1. Yorita KL, Holman RC, Sejvar JJ, Steiner CA, Schonberger LB. Infectious disease hospitalizations among infants in the United States. Pediatrics. 2008;121(2):244-252

2. de Jong J, van den Berg PB, Visser ST, de Vries TW, de Jong-van den Berg LT. Antibiotic usage, dosage and course length in children between 0 and 4 years. Acta Paediatr. 2009;98(7):1142-1148

3. Low D. Reducing antibiotic use in influenza: challenges and rewards. Clin Microbiol Infect. 2008; 14(4):298-306

4. Freymuth F, Vabret A, Cuvillon-Nimal D, et al. Comparison of multiplex PCR assays and conventional techniques for the diagnostic of respiratory virus infections in children admitted to hospital with an acute respiratory illness. J Med Virol. 2006;78(11):1498-1504

5. leven M. Currently used nucleic acid amplification tests for the detection of viruses and atypicals in acute respiratory infections. J Clin Virol. 2007;40(4): $259-276$

6. Schauer U, Ihorst G, Rohwedder A, et al. Evaluation of respiratory syncytial virus detection by rapid antigen tests in childhood. Klin Padiatr. 2007;219(4):212-216

7. Aslanzadeh J, Zheng $X, \mathrm{Li} \mathrm{H}$, et al. Prospective evaluation of rapid antigen tests for diagnosis of respiratory syncytial virus and human metapneumovirus infections. J Clin Microbiol. 2008;46(5):1682-1685

8. Selvarangan R, Abel D, Hamilton M. Comparison of BD Directigen EZ RSV and Binax NOW RSV tests for rapid detection of respiratory syncytial virus from nasopharyngeal aspirates in a pediatric population. Diagn Microbiol Infect Dis. 2008;62(2):157-161

9. Doan $\mathrm{QH}$, Kissoon N, Dobson $\mathrm{S}$, et al. A randomized, controlled trial of the impact of early and rapid diagnosis of viral infections in children brought to an emergency department with febrile respiratory tract illnesses. J Pediatr. 2009;154(1):91-95

10. Byington $\mathrm{CL}$, Castillo H, Gerber K, et al. The effect of rapid respiratory viral diagnostic testing on antibiotic use in a children's hospital. Arch Pediatr Adolesc Med. 2002; 156(12):12301234

11. Woo PCY, Chiu SS, Seto WH, Peiris M. Costeffectiveness of rapid diagnosis of viral respiratory tract infections in pediatric patients. J Clin Microbiol. 1997;35(6): 1579-1581

12. Barenfanger J, Drake C, Leon N, Mueller T, Troutt T. Clinical and financial benefits ofrapid detection of respiratory viruses: an outcomes study. J Clin Microbiol. 2000;38(8):2824-2828

13. Oosterheert JJ, van Loon AM, Schuurman R, et al. Impact of rapid detection of viral and atypical bacterial pathogens by real-time polymerase chain reaction for patients with lower respiratory tract infection. Clin Infect Dis. 2005;41(10):1438-1444

14. van de Pol AC. Molecular Detection of Respiratory Viruses: Clinical Impact [master's thesis]. Utrecht, Netherlands: Utrecht University; 2009

15. Rietveld E, De Jonge HC, Polder JJ, et al. Anticipated costs of hospitalization for respiratory syncytialvirusinfectioninyoungchildrenatrisk. Pediatr Infect Dis J. 2004;23(6):523-529

16. FloodRG,Badik J, AronoffSC. Theutility of serum C-reactive protein in differentiating bacterial from nonbacterial pneumonia in children: a meta-analysisof1230children. Pediatr Infect Dis J. 2008;27(2):95-99

17. Sung RYT, Chan PKS, Tsen T, et al. Identification of viral and atypical bacterial pathogens in children hospitalized with acute respiratory infections in Hong Kong by multiplex PCR assays. J Med Virol. 2009; 81(1):153-159

18. Bharaj P, Sullender WM, Kabra SK, et al. Respiratory viral infections detected by multiplex PCR among pediatric patients with lower respiratory tract infections seen at an urban hospital in Delhi from 2005 to 2007. Virol J. 2009;6(1):89 
19. Brittain-Long R, Nord S, Olofsson S, Westin J, Anderson LM, Lindh M. Multiplex real-time PCR fordetection of respiratory tract infections. J Clin Virol. 2008;41(1):53-56

20. Arnold JC, Singh KK, Spector SA, Sawyer MH. Undiagnosed respiratory viruses in children. Pediatrics. 2008;121(3). Available at: www. pediatrics.org/cgi/content/full/121/3/e631

21. Pierangeli A, Gentile M, Di Marco P, et al. Detection and typing by molecular techniques of respiratory viruses in children hospitalized for acute respiratory infection in Rome, Italy. J Med Virol.2007;79(4):463-468

22. van de Pol AC, Wolfs TFW, Jansen NJG, van Loon AM, Rossen JWA. Diagnostic value ofrealtime polymerase chain reaction to detect viruses in young children admitted to the paediatric intensive care unit with lower respiratory tract infection. Crit Care. 2006;10(2):R61

23. Bakaletz LO. Viral potentiation of bacterial superinfection of the respiratory tract. Trends Microbiol. 1995;3(3):110-114

24. Peltola VT, McCullers JA. Respiratory viruses predisposing to bacterial infections: role of neuraminidase. Pediatr Infect Dis J. 2004;23(1 suppl):S87-S97

25. Stadhouders R, Pas SD, Anber J, Voermans J, MesTH, Schutten M. The effect of primertemplate mismatches on the detection and quantification of nucleic acids using the $5^{\prime}$ nuclease assay. J Mol Diagn. 2010;12(1): 109-117 


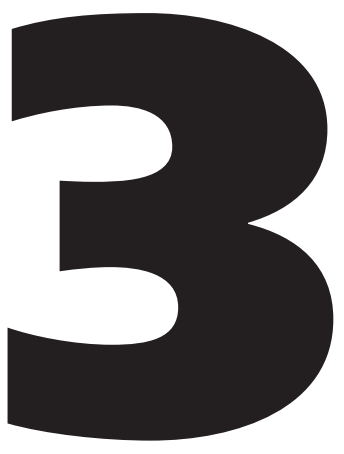




\section{SINGLE- AND MULTIPLE VIRAL RESPIRATORY INFECTIONS}

IN CHILDREN: DISEASE AND MANAGEMENT CANNOT BE RELATED TO A SPECIFIC PATHOGEN

Jérôme O. Wishaupt, Tjeerd van der Ploeg, Ronald de Groot, Florens G. A. Versteegh and Nico G. Hartwig 


\section{ABSTRACT \\ Background}

The number of viral pathogens associated with pediatric acute respiratory tract infection (ARI) has grown since the introduction of reverse transcription real-time polymerase chain reaction (RT-PCR) assays. Multiple viruses are detected during a single ARI episode in approximately a quarter of all cases. The clinical relevance of these multiple detections is unclear, as is the role of the individual virus. We therefore investigated the correlation between clinical data and RT-PCR results in children with single- and multiple viral ARI.

\section{Methods}

Data from children with ARI were prospectively collected during two winter seasons. RT-PCR testing for 15 viruses was performed in 560 ARI episodes. In the patients with a single-viral etiology, clinical data, laboratory findings, patient management- and outcome data were compared between the different viruses. With this information, we compared data from children of whom RT-PCR data were negative, with children with single- and multiple viral positive results.

\section{Results}

The viral detection rate was $457 / 560$ (81.6\%) of which $331 / 560$ (59.1\%) were single infections and 126/560 (22.5\%) were multiple infections. In single viral infections, some statistically significant differences in demographics, clinical findings, disease severity and outcome were found between children with different viral etiologies. However, no clinically recognizable pattern was established to be virus-specific. In a multivariate analysis, the only variables that were correlated with longer hospital stay were the use of oxygen and nebulizer therapy, irrespective of the viral pathogen. Children with RT-PCR positive test results had a significant higher disease severity, fever, length of hospital stay, days of extra oxygen supply, and days of antibiotic treatment than children with a negative RT-PCR test result. For children with single- versus children with multiple positive RT-PCR test results, these differences were not significant.

\section{Conclusions}

Disease (severity), management and outcome in pediatric ARI are not associated with a specific virus. Single- and multiple viral ARI do not significantly differ with regard to clinical outcome and patient management. For general pediatrics, RT-PCR assays should be restricted to pathogens for which therapy is available or otherwise may have clinical consequences. Further research with an extended panel of RT-PCR assays and a larger number of inclusions is necessary to further validate our findings.

\section{Keywords}

Respiratory tract infections, Child, Co-infection, Respiratory Syncytial Virus, Respiratory viruses 


\section{BACKGROUND}

Acute respiratory tract infections (ARI) frequently occur in young children. Assessment of disease severity is often difficult and repeated observation over time is recommended. ${ }^{1}$ Most ARI's in young children are of viral origin. Traditionally, clinical guidelines on this subject focus primarily on Respiratory syncytial virus (RSV) and Influenza virus (FLU), as these are considered the most significant viral pathogens. ${ }^{1,2}$ Risk factors for a more severe disease course are best known for RSV, ${ }^{3,4}$ although these fail to predict outcome in individual patients. Nowadays, real-time reverse transcription polymerase chain reaction (RT-PCR) assays have been introduced in many hospitals and the number of viruses found in nasal wash specimens (NWS) of children with ARI is growing. The role of many of these viruses in disease severity and clinical course is still unclear, since studies differ with regard to design, age at inclusion, recruitment criteria, the manner of data collection, assay sensitivity and the type of viruses studied. ${ }^{5}$ RT-PCR test results are positive in up to $72-95 \%$ of symptomatic children and up to $40-68 \%$ of asymptomatic children, depending on age, diagnosis and detection method. ${ }^{6}$ At the same time, the number of viral co-infections which are detected by RT-PCR has also grown to $43 \% .{ }^{6}$ Interpretation of these test results is even more challenging. Literature on this subject is growing. Some reports suggest there is no relation between multiple respiratory viral infections and disease severity, ${ }^{7-11}$ while others report a higher disease severity in children with a multiple respiratory infection. 12,13 Practical dilemmas about cohorting of patients with different viral pathogens have not yet been solved. ${ }^{14}$

In a previous controlled clinical trial, we showed that rapid reporting of RT-PCR test results to the pediatrician did not influence patient care. ${ }^{15}$ The aim of the current study was to determine if RT-PCR test results are related to clinical data in children with respiratory symptoms. We investigated clinical symptoms, management and outcome in these children and correlated these findings to the specific virus determined by RT-PCR. We additionally investigated clinical differences between single-, multiple-, and RT-PCR negative ARI.

\section{METHODS}

\section{Study design}

This study is part of the EVIDENCE-trial (Evaluation of Viral Diagnostics on Respiratory Infections in Children), a multi-center, controlled clinical trial to evaluate viral RT-PCR diagnostics for ARI in pediatric patients..$^{15}$ In summary, the trial was conducted during two consecutive winter seasons (2007-2008 and 2008-2009) in two Dutch teaching hospitals with comparable populations: the Reinier de Graaf Hospital in Delft joined in the second season by the Groene Hart Ziekenhuis in Gouda. The EVIDENCE studyprotocol was approved by the regional Medical Ethics Committee (CCMO number 
NL13839.098.06). In the current study, a selection of the EVIDENCE-dataset is used to analyze the clinical aspects in relation to the viral pathogens.

\section{Patients}

Children younger than 12 years old with respiratory symptoms, who visited the emergency department or pediatric outpatient clinic, were included. More than $90 \%$ of these children were assessed by the primary physician before referral to the hospital. Informed consent for study participation was sought after the NWS was obtained, because nasal washings are part of standard diagnostic procedures. Indications for hospital admission were made on clinical grounds, e.g. need for extra oxygen, feeding difficulties, apneas as observed by the parents. Children with underlying anatomical airway abnormalities (e.g. bronchopulmonary dysplasia) or other significant underlying disorders (e.g. syndromal disorders, psychomotor retardation, malignancies) were excluded. We also excluded newborns that had been hospitalized since birth. Patients with asthma or suspected asthma were not excluded. Patients could be included multiple times during the two study periods, provided that sampling of NWS was at least 14 days apart to ensure that the children had a new episode of ARI. In addition, patient data were reviewed retrospectively to certify that the sample was taken in a second episode of respiratory symptoms. Patients with positive RT-PCR results for Chlamydophila pneumoniae, Mycoplasma pneumoniae and Bordetella pertussis as single or multiple infection were excluded in order not to trouble comparisons of the virus groups with respect to clinical data. Patients with a positive viral RT-PCR and a clinical confirmed pneumonia were not excluded. Blood cultures or other bacterial cultures were not standard procedures, but were performed on clinical grounds. Patient enrollment criteria are presented in Figure 1.

\section{Definitions}

ARI was defined as a new episode of respiratory symptoms of the upper and/or lower airways. Upper respiratory tract infection (URTI) was defined as any episode of rhinorrhea, nasal congestion, sore throat, erythematous pharynx, earache or erythematous eardrum. Lower respiratory tract infection (LRTI) was defined as respiratory symptoms with tachypnea and abnormal pulmonary auscultation; rales, crackles, crepitations, wheezing or prolonged expiration. Hypoxia was defined as a pulse oximetric peripheral oxygen saturation of $<92 \%$ and was not a criterion for LRTI, as it is involved in URTI as well. X-ray confirmation also was not used in the definition, because of a restricted use of ionizing radiation in pediatric practice. Tachypnea was defined by age-dependent cut-off values. ${ }^{16}$ Wheeze was defined as high-pitched whistling sound heard coming from the chest on expiration. Apnea was defined as one or more episodes of respiratory pauses regardless of duration observed by caretakers, physicians or nurses. Dyspnea was defined as difficulty of breathing with chest retractions, use of auxiliary respiratory muscles or nose flaring. In single-, 
Nasal washing specimens analyzed during two winter seasons $n=776$

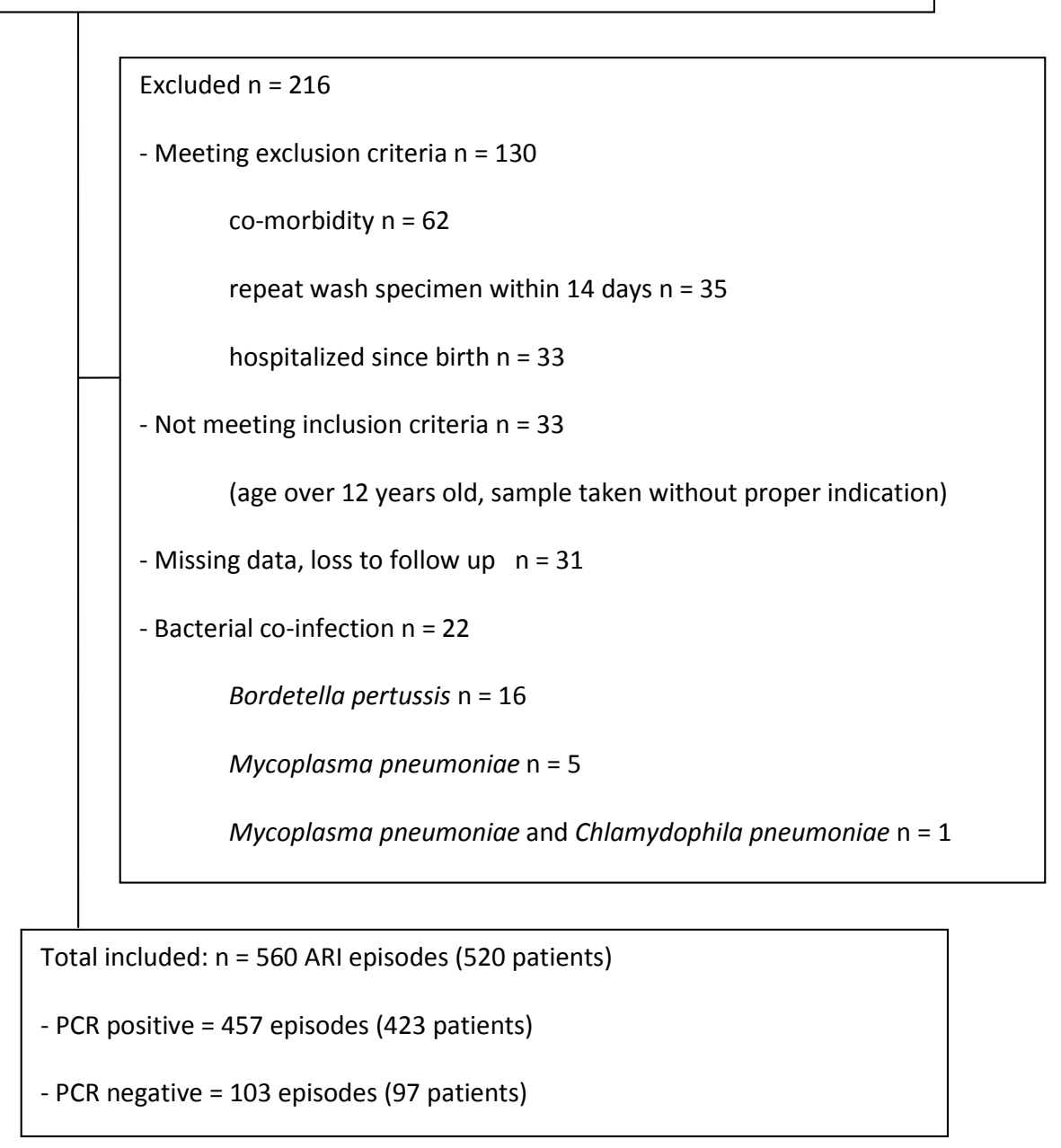

Figure 1. Patient enrollment.

dual- and multiple infections, RT-PCR was positive for respectively one, two or more than one virus.

\section{Data collection}

Clinical data were prospectively collected with use of a standardized form by the treating physician. Tables 1, 2 and 3 summarize the data collected. Missing information, laboratory results and, when available, radiology reports were retrieved from the patient's medical electronic record. 


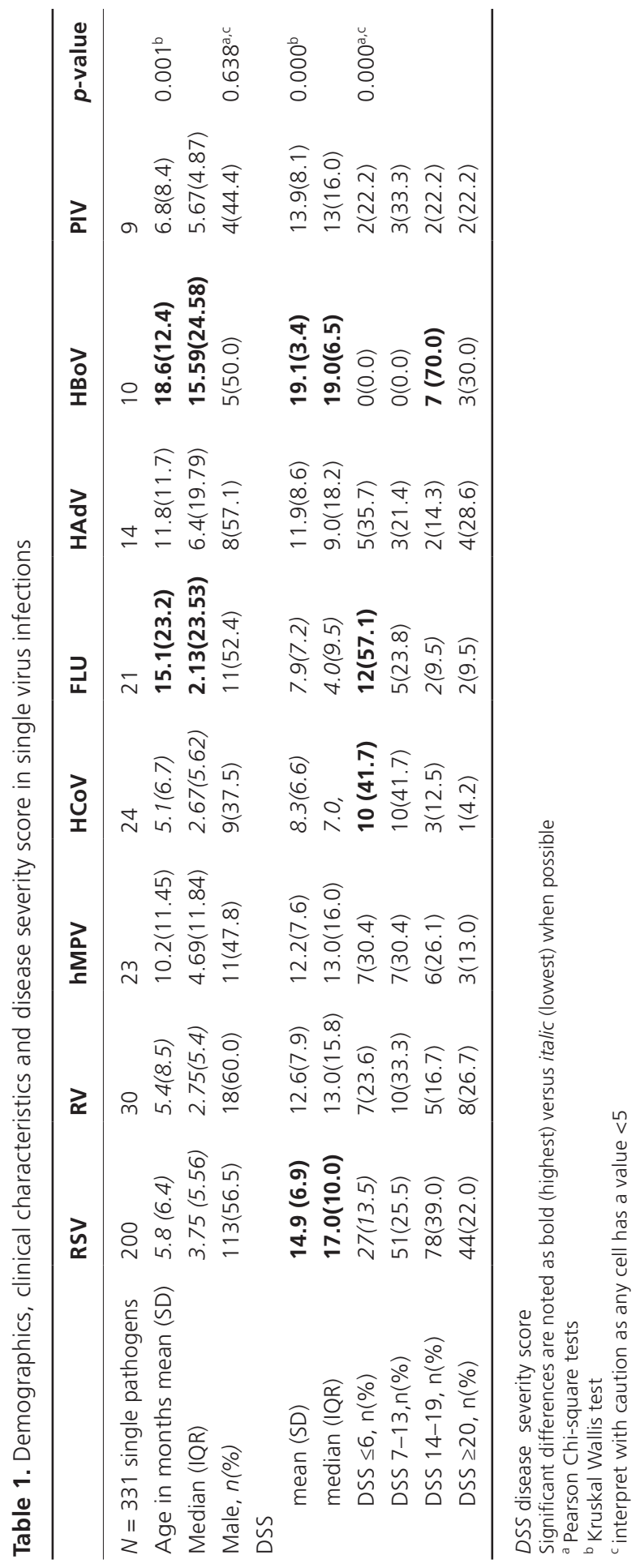




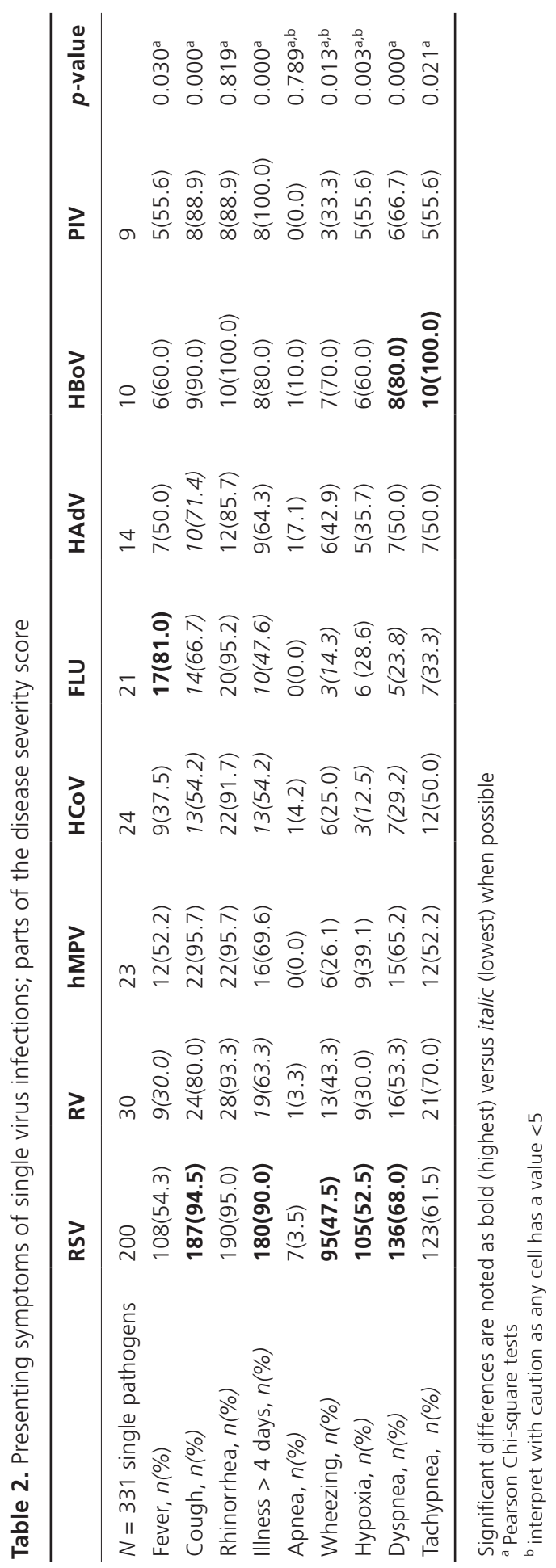

3 


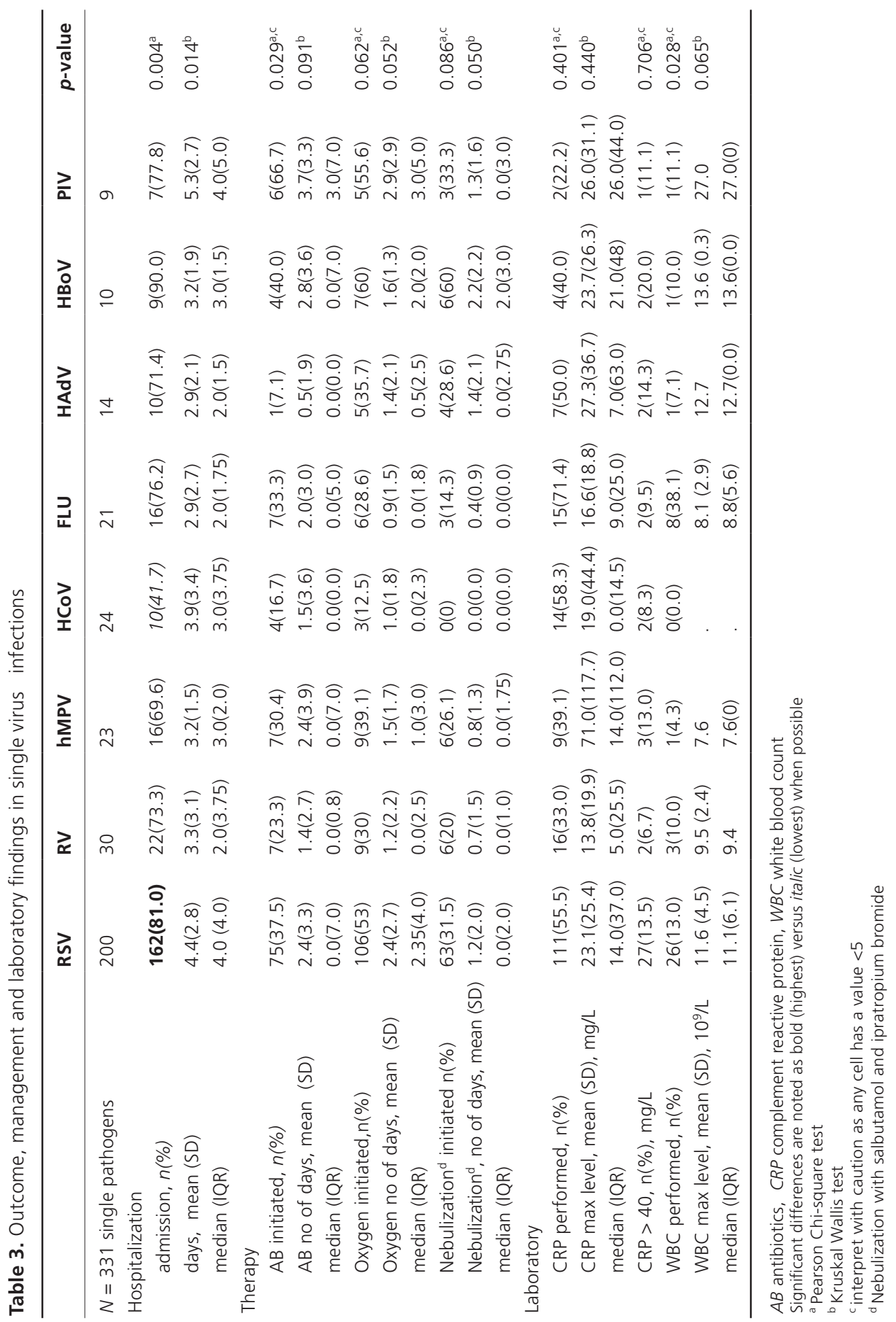




\section{Disease severity score (DSS)}

The DSS used in this study is a modification of the one used by Gern et al. ${ }^{17}, 18$ (Supplementary Table 1). In the original score, cough and rhinorrhea are subdivided in mild, moderate and severe. We could not make that subjective distinction in our dataset. Hoarseness was also not included in our score. In the original score, the maximum was 31; in our modified score the maximum is 27.

\section{Respiratory pathogens}

All samples were tested for RSV with a rapid bedside test and supplementary RT-PCR assays were performed for 15 viruses and 2 bacteria (Chlamydophila pneumoniae and Mycoplasma pneumoniae). RT-PCR for Bordetella pertussis was performed only on clinical suspicion and retrospectively in all available samples. ${ }^{19}$ A description of the RT-PCR method and validation procedure is published elsewhere. ${ }^{15}$ Viral subtypes were clustered into virus groups in order to have sufficient patient-numbers in each virus group. RSV-A and RSV-B were clustered. Human Coronavirus (HCoV) 229E, HCoV-NL63 and HCOV-OC43 were clustered. FLU-A and FLU-B were clustered, as well as Parainfluenza virus (PIV) 1, 2, 3 and 4. Other viruses included rhinovirus (RV, not divided in subgroups), Human Metapneumovirus (hMPV), Human Adenovirus (HAdV) and Human Bocavirus (HBoV). We did not study SARS Coronavirus, Human Coronavirus HKU1, enterovirus, Polyomavirus WU and KI.

\section{Other diagnostic procedures}

Other diagnostic tests were only performed on clinical grounds: white blood count, C-reactive protein (Table 3), blood cultures and X-rays (data not shown).

\section{Statistical analysis}

Statistical analysis was performed using IBM SPSS Statistics 21.0 (SPSS inc., IBM Company, Chicago, Illinois). For the comparison of categorical or dichotomous variables with the pathogen groups, we used Pearson Chi-squared tests. For the comparison of continuous variables, we used Kruskal-Wallis- and MannWhitney tests. For all tests, a p-value $<0.05$ was considered significant. Multiple regression analysis was used to analyze the relation between age, DSS, LRTI, antibiotic initiated, number of days with antibiotics, number of days with extra oxygen, number of days with nebulization, the virus groups and the outcome days in hospital. A p-value $<0.05$ was considered as significant.

\section{RESULTS}

\section{Patient enrollment}

During the two study periods, a total of 776 NWS were analyzed. 216 were excluded. In total, 560 viral ARI episodes (520 patients) were analyzed (flowchart, Figure 1). 


\section{Demographics}

The mean age in this study was 7.9 months and $60.5 \%$ was male. Single- and multiple infections did differ significantly in age ( 7.3 versus 9.0 months, $p<0.001)$, sex $(54.1 \%$ versus $64.3 \%$ male, $p=0.049)$ and daycare attendance $(30.8 \%$ versus $48.0 \%, p=0.002)$. Patient reported family history of an atopic constitution was $56.5 \%$ and did not significantly differ between the virus groups.

\section{Viral results}

The detection rate of viruses by RT-PCR was 457/560 (81.6\%) (Table 4). Singleinfections were detected in 331 out of 560 (59.1\%) ARI episodes. Multiple infections were detected in $126 / 560$ (22.5\%) episodes of which $106 / 560$ (18.9\%) were dual infections, $18 / 560$ (3.2\%) were triple infections and 2/560 (0.4\%) were quadruple infections. A negative RT-PCR was present in 103/560 (18.4\%) episodes.

RSV was positive in 200/331 single infections (60.4\%), 78/106 (73.6\%) dual infections and $91 / 126(72.2 \%)$ multiple infections. RSV was positive in all of the most frequent combinations of dual infections (data not shown).

The distribution of the viruses per month is shown in Fig. 2. Peak incidence of FLU in both seasons was in January and February. Other viruses were isolated throughout both winter seasons.

Table 4. RT-PCR Results in children with acute respiratory tract infections

\begin{tabular}{|c|c|c|c|c|c|c|}
\hline $\begin{array}{l}\text { RT-PCR } \\
\text { results }\end{array}$ & $\mathbf{N}$ & $\begin{array}{l}\text { Proportion out } \\
\text { of total } \\
\text { ( } n=560 \text { cases) }\end{array}$ & $\begin{array}{l}\text { Detection } \\
\text { in single } \\
\text { infections }\end{array}$ & $\begin{array}{l}\text { Proportion out } \\
\text { of total single } \\
\text { infections } \\
(n=331)\end{array}$ & $\begin{array}{l}\text { Detection } \\
\text { in multiple } \\
\text { infections }\end{array}$ & $\begin{array}{l}\text { Proportion out } \\
\text { of total multiple } \\
\text { infections } \\
(n=126)\end{array}$ \\
\hline Negative & 103 & $18.4 \%$ & & & & \\
\hline Single & 331 & $59.1 \%$ & & & & \\
\hline Dual & 106 & $18.9 \%$ & & & & \\
\hline Triple & 18 & $3.2 \%$ & & & & \\
\hline Quadruple & 2 & $0.4 \%$ & & & & \\
\hline RSV & 291 & $52.0 \%$ & 200 & $60.4 \%$ & 91 & $72.2 \%$ \\
\hline RV & 72 & $12.9 \%$ & 30 & $9.1 \%$ & 42 & $33.3 \%$ \\
\hline $\mathrm{HCOV}$ & 71 & $12.7 \%$ & 24 & $7.3 \%$ & 47 & $37.3 \%$ \\
\hline HAdV & 45 & $8.0 \%$ & 14 & $4.2 \%$ & 31 & $24.6 \%$ \\
\hline hMPV & 42 & $7.5 \%$ & 23 & $6.9 \%$ & 19 & $15.1 \%$ \\
\hline FLU & 33 & $5.9 \%$ & 21 & $6.3 \%$ & 12 & $9.5 \%$ \\
\hline PIV & 29 & $5.2 \%$ & 9 & $2.7 \%$ & 20 & $15.9 \%$ \\
\hline HBoV & 22 & $3.9 \%$ & 10 & $3.0 \%$ & 12 & $9.5 \%$ \\
\hline
\end{tabular}

RSV Respiratory Syncytial Virus, RV Rhinovirus, HCoV Human Coronavirus, HAdV Human Adenovirus, hMPV Human metapneuvirus, FLU Influenzavirus, PIV

Parainfluenza virus, HBoV Human Bocavirus 


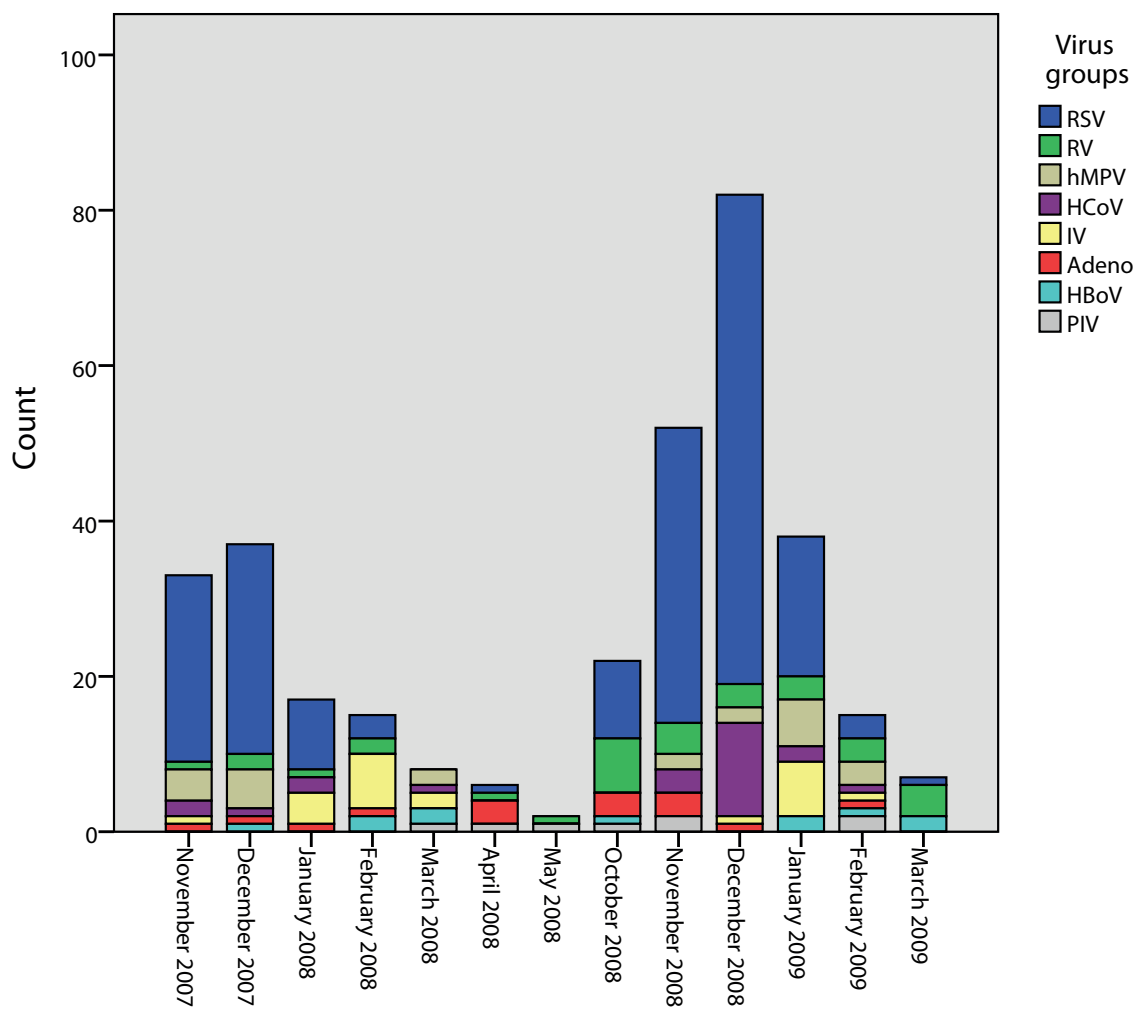

Sample Date

Figure 2. Distribution of virus groups: count per month. Abbriviations: RSV, respiratory syncytial virus. RV, rhinovirus. hMPV, human metapneumovirus. HCoV, human coronavirus. FLU, influenza virus. HAdV, adenovirus. HBoV, human bocavirus. PIV, parainfluenza virus.

The original study was a randomized controlled clinical trial. ${ }^{15} \mathrm{~A}$ chi-square test showed an equal distribution of the virus groups between intervention- (rapid reporting of PCR-results to the clinician) and the control (late reporting) group (data not shown).

\section{Clinical symptoms and management of single viral infections}

The overall admission rate in single viral infections was 252/331 (76.1\%). Extra oxygen supply was administered to 149/252 (59.1\%) and nebulizer therapy to $91 / 252$ (36.1\%) hospitalized children. Although the $\mathrm{p}$-value indicated a significant difference between the virus groups with regard to the number of times that antibiotics were initiated, it was not possible to explore this difference using the Pearson Chisquare test. There were no significant differences between the virus groups with regard to the mean number of days with antibiotic treatment, extra oxygen supply, nebulizer therapy and the number of children with feeding problems due to 
respiratory distress, resulting in a need for tube feeding. There were also no significant differences between the virus groups regarding mean or maximum CRP count and mean or maximum white blood count (Table 3).

The multivariate analysis for length of hospital stay (LOS) included age, DSS, LRTI, antibiotic treatment, oxygen therapy, nebulizing therapy and single virus groups. In the univariate analysis, RSV and RV were the virus groups that were correlated with longer hospital stays. In the multivariate analysis, the only variables that were correlated with longer hospital stays were oxygen therapy and nebulizer therapy, irrespective of the viral pathogen. For DSS, there was a significantly adjusted pvalue, whereas the multivariate regression coefficient was negative (Table 5). In a multivariate sub analysis for oxygen therapy including RSV, RV and FLU, RSV was significantly correlated with longer duration of oxygen therapy $(p=0.020)$. For nebulizer therapy and duration of antibiotic treatment, there was no significant correlation with these viruses (data not shown).

The characteristics per virus group are presented in Tables 1, 2 and 3 and are highlighted per virus group below.

\section{RSV}

RSV was the most frequently detected virus and was found in 200 out of 331 $(60.4 \%)$ single infections. The mean age of children with RSV was 5.8 months and

Table 5. Multivariate analysis in single viral respiratory tract infection with regard to Length of Hospital Stay

\begin{tabular}{lcccc}
\hline Variable & $\begin{array}{l}\text { Univariate } \\
\text { Spearman's } \rho\end{array}$ & $\boldsymbol{p}_{\text {-value }}$ a $^{\text {Multivariate }}$ & $\begin{array}{l}\text { Megression } \\
\text { coefficient }\end{array}$ & $\begin{array}{c}\text { Adjusted } \\
\boldsymbol{p} \text {-value }\end{array}$ \\
\hline Age & -0.096 & .128 & -0.019 & 0.165 \\
DSS & 0.371 & $<0.01$ & -0.038 & 0.052 \\
AB initiated & 0.334 & $<0.01$ & 0.352 & 0.571 \\
AB no of days & 0.336 & $<0.01$ & 0.026 & 0.769 \\
FiO2 no of days & 0.671 & $<0.01$ & 0.885 & $<0.01$ \\
Nebulizer & 0.120 & $<0.01$ & 0.293 & 0.005 \\
RSV & & $<0.01$ & 0.306 & 0.226 \\
RV & & 0.022 & 0.409 & 0.324 \\
hMPV & 0.446 & & \\
HCoV & & 0.623 & & \\
FLU & & 0.024 & & \\
HAdV & 0.125 & & \\
HboV & 0.470 & & \\
PIV & & 0.128 & & \\
\hline
\end{tabular}

${ }^{a}$ For continuous variables, Mann-Whitney $U$ tests were used 
they were significantly younger than children with FLU or HBoV. RSV positive children were significantly more often hospitalized than HCoV positive children. The DSS for children with RSV and HBoV was significantly higher than for those with HCOV and FLU. The mean DSS for RSV was 14.9, the second highest after HBoV (DSS 19.1). This was significantly higher than for instance FLU (DSS 7.9). Apneas occurred in $7 / 200$ (3.5\%) of RSV single infections. One child was RTPCR positive for RSV as single pathogen, despite a first vaccination with palivizumab. It was a 2 month old boy born after 32 weeks of gestation with a mild disease course (DSS 13, LOS 4). None of the children in the study were treated with the antiviral drug ribavirin.

\section{Rhinovirus}

RV was the second most commonly identified single virus infection (30/331, 9.1\%). The mean age of children with RV was young; 5.4 months. The DSS was not significantly different compared to those of other viruses. Human metapneumovirus: For hMPV, there were no significant differences compared to the other viruses with regard to age, DSS and admission rate.

\section{Coronavirus}

Children with HCoV had the lowest mean age (5.1 months) of all virus groups. The mean DSS was 8.6, which was significantly lower than for RSV or HBoV. The admission rate was 10/24 (41.7\%), the lowest of all virus groups.

\section{Influenzavirus}

The mean age at onset of disease for FLU was 15.1 months, which was significantly higher than for RSV and some other viruses. The mean DSS was 7.9, lowest of all virus groups and significantly lower than for RSV. None of the patients was treated with antiviral drugs like oseltamivir.

\section{Adenovirus}

For HAdV, there were no significant differences compared to the other viruses with regard to DSS and admission rate.

\section{Bocavirus}

The mean age of children with HBoV was 18.6 months, which was significantly higher than for RSV, RV and HCOV. The mean DSS was also highest (19.1), which was significantly higher than for FLU. The admission rate was 9/10 (90.0\%). Although the admission rate was the highest of all virus groups, this difference was not significant. The mean number of days of nebulization therapy with salbutamol and ipratropium bromide was 2.2 (SD 2.2) days, highest of all, although this was not significant compared to the other viruses. 


\section{Parainfluenzavirus}

The mean DSS for children with PIV was 13.9, third highest after HBoV and RSV. The number of times that antibiotics were initiated was highest for PIV $(6 / 9,66.7 \%)$

\section{Clinical symptoms and management of multiple viral infections}

Patients with a confirmed viral ARI had a significantly higher DSS, fever, LOS, extra oxygen supply and antibiotic treatment than patients with a negative RT-PCR result (Table 6). Nebulizer therapy and the admission rate did not significantly differ between these groups.

Within the group of viral confirmed ARI, children with single- and multiple viral infections did not significantly differ with regard to DSS, fever, admission rate, LOS, extra oxygen supply, nebulizer therapy and duration of antibiotic treatment when initiated (Table 6). Sub analysis per group was performed for RT-PCR negative, single-, dual-, triple- and quadruple infections. No significant differences were found (data not shown).

A sub analysis of the five most common dual viral combinations (RSV/HCoV, RSV/RV, RSV/HAdV, RSV/hMPV, RSV/PIV) was performed in order to investigate whether these groups differed in clinical symptoms and management. There were no significant differences between the groups with regard to DSS ( $p=0.958)$, admission rate $(p=0.318)$, LOS $(p=0.906)$, extra oxygen supply $(p=0.456)$, nebulizer therapy $(p=0.210)$ and antibiotic treatment $(p=0.339)$ (data not shown).

Table 6. Clinical symptoms and management in RT-PCR negative, positive, single- and multiple ARI

\begin{tabular}{|c|c|c|c|c|c|c|}
\hline & $\begin{array}{l}\text { RT-PCR } \\
\text { negative }\end{array}$ & $\begin{array}{l}\text { RT-PCR } \\
\text { positive }\end{array}$ & $p$-value ${ }^{a}$ & $\begin{array}{l}\text { Single } \\
\text { ARI }\end{array}$ & $\begin{array}{l}\text { Multiple } \\
\text { ARI }\end{array}$ & $p$-value \\
\hline DSS, mean & 8.83 & 13.83 & 0.000 & 13.57 & 14.51 & 0.243 \\
\hline Fever n/total (\%) & $\begin{array}{l}37 / 103 \\
(35.9)\end{array}$ & $\begin{array}{l}243 / 457 \\
(53.2)\end{array}$ & 0.002 & $\begin{array}{l}173 / 331 \\
(52.3)\end{array}$ & $\begin{array}{l}70 / 126 \\
(55.6)\end{array}$ & 0.529 \\
\hline Admission n/total, (\%) & $\begin{array}{l}74 / 103 \\
(71.8)\end{array}$ & $\begin{array}{l}342 / 457 \\
(74.8)\end{array}$ & 0.530 & $\begin{array}{l}252 / 331 \\
(76.1)\end{array}$ & $\begin{array}{l}90 / 126 \\
(71.4)\end{array}$ & 0.300 \\
\hline LOS (days) & 2.99 & 3.95 & 0.003 & 4.02 & 3.76 & 0.432 \\
\hline Oxygen supply (days) & 0.85 & 1.98 & 0.000 & 1.99 & 1.96 & 0.912 \\
\hline Nebulizer therapy (days) & 1.03 & 1.19 & 0.227 & 1.10 & 1.46 & 0.140 \\
\hline Antibiotics (days) & 1.56 & 2.32 & 0.041 & 2.19 & 2.67 & 0.190 \\
\hline
\end{tabular}

$A R I$ acute respiratory tract infection, $R T$-PCR reverse-transcriptase real-time polymerase chain reaction, DSS disease severity score, LOS length of hospital stay

a Significant differences are noted as bold 


\section{DISCUSSION}

In this study, we investigated clinical presentation, management and outcome in a large cohort of patients with viral ARI and correlated these findings to the specific virus that was established by RT-PCR. Despite some significant differences, no clinically recognizable pattern per virus group was found. In addition, we showed that children with single- and multiple viral ARI did not differ with regard to clinical outcome.

\section{Single infections}

The high number of RSV positive children, their young age, high admission rate and high DSS was expected since RSV is well known to have a great disease burden in young children. ${ }^{20} \mathrm{RV}$ usually is the most frequently found virus in young children and Enteroviridae peak in late summer and autumn. ${ }^{21}$ However, in our study, RV was not frequently found as a single pathogen, possibly due to the sampling period in the winter. The high admission rate and moderate DSS stresses the growing evidence that RV is associated with a more severe ARI in young children. ${ }^{22-24}$

In our study, clinical data of patients with hMPV did not differ to patients with other viruses. This is in line with literature, in which patients with RSV and hMPV were virtually indistinguishable with regard to symptoms and laboratory findings. ${ }^{25}$ We did not find the typical male to female ratio of two to one, as reported earlier. ${ }^{26}$

For the Coronavirus group, DSS, percentage of hospitalizations, the number of days with extra oxygen and the number of days with nebulization was low, suggesting a mild disease course. This was in contrast with the relative high median number of days in hospital. Only one specific patient was responsible for this effect. It was a 2 year old boy with a double sided pneumonia, DSS 19, maximum CRP $51 \mathrm{mg} / \mathrm{ml}$, treated with intravenous antibiotics for 7 days.

The mean age of children positive for FLU was relatively high and most children were infected during the second winter season in their life. A possible explanation for this phenomenon is that the influenza-season lasts only a few weeks during a winter season. ${ }^{21}$ As adults are also frequently infected, young children may be protected by circulating maternal antibodies against FLU during the first months of their life. ${ }^{27}$ The low DSS for FLU was also remarkably as FLU is considered a potential virulent pathogen, especially in young children. ${ }^{2}$ Possibly our inclusion criteria (children with ARI) may miss children with fever without a source or a sepsis like syndrome as is frequently seen in young children with influenza. Another important note is that our inclusion period was before the FLU-A H1N1 2009 pandemic occurred. The circulating FLU-A strains have changed in composition and this may have an effect on the clinical presentation of FLU nowadays. A recent study showed a more severe disease course in children with FLU-A compared to FLU-B. ${ }^{28}$

The DSS for HBoV was high in our study. Similar results were found in a recent study showing that HBoV as a single pathogen can cause severe ARI. ${ }^{29}$ The mean age of children with HBoV in our study was significantly higher than for children with 
RSV, RV and HCoV, which has not been reported before. A possible explanation is again protection by maternal antibodies. As reviewed by Jartti, protection by vertical antibody transfer is common at age $<2$ months. After this age HBoV antibody-titers decline and are lowest at age 6-12 months. After 12 months seroprevalence of HBoV increases again until age 6 years. At that time almost all children have circulating HBoV antibodies. ${ }^{30}$

Apneas are an important concern in young children with bronchiolitis. In our study, apneas occurred in seven out of 200 (3.5\%) RSV single infections, comparable with data found in a recent review. ${ }^{31}$ However, apneas occurred also in non RSVinfections $(4 / 131,3.1 \%)$. The clinical data and risk factors for children with apneas have been published elsewhere. ${ }^{18}$

Although we showed some significant differences in clinical data between the virus groups, a specific clinically recognizable pattern per virus group could not be defined. All virus groups showed overlapping clinical symptoms.

\section{Multiple infections}

Patients with a positive RT-PCR result were different from children with a negative RT-PCR result, except for admission rate and nebulization therapy (Table 6). A possible explanation is that asthma patients were not excluded in this study and nebulization therapy is sometimes started as test treatment in children with ARI and wheezing episodes. Patients with multiple infections were significantly older than patients with single infections, as is also previously reported. ${ }^{11,32} \mathrm{~A}$ possible explanation is a higher daycare attendance in older children, where crowding of children leads to virus transmission. ${ }^{33,34}$ Indeed, in our study daycare attendance appeared more often in children with a multiple infection.

\section{General discussion}

Patients could be included multiple times in our study. To ensure that this was not in the same period of illness, an interval of at least 14 days between two NWS samples was chosen. In a sub analysis of the repeat cases, RT-PCR showed different viruses in 34 out of 35 patients between the first and second illness period. In one patient, both NWS were positive for RSV-A, but these samples were taken in different years. In 22 out of these 35 patients, RT-PCR was positive for multiple viruses.

There is increasing interest in the importance of viral load. Whether viral load, determined by cycle threshold values of RT-PCR assays may contribute to disease severity and/or to a better understanding of the role of multiple infections lay outside the scope of this study. This subject will be addressed in a separate paper.

A limitation of this study is the small number of patients in some virus groups, even after clustering of viral subtypes. This might have led to over- or underestimation of some effects. The clustering of different virus subtypes itself could potentially lead to underestimation of some more harmful subtypes. Some investigators showed a more 
severe disease course of RV subtype $C,{ }^{35}$ while others found a similar disease severity between subtypes $A$ and $C .{ }^{36}$ Our RT-PCR assay could not differentiate between different subtypes of RV. For RSV, an equal disease severity between the subtypes $A$ and $B$ is assumed. ${ }^{37}$ We clustered FLU-A and FLU-B, and as mentioned above, inclusion of patients was before the FLU-A H1N1 2009 pandemic occurred. Secondly, bias may have been introduced in our study since most children were referred to the hospital only after initial assessment by a primary care physician, as is common in the Dutch healthcare system. Therefore, patients with milder disease may be underrepresented; this is also reflected in the high admission rate of $76.1 \%$ in singleinfections and $74.3 \%$ in all ARI's in this study. We used a modified scoring system to avoid subjective terms like moderate or severe. A concern in the interpretation of clinical severity using a DSS is the lack of uniformity between scoring systems for young children with ARI in literature. The severity score of Gern et al. was also used in a study correlating viral load and disease severity of RSV patients. ${ }^{38}$ We also used a modification of this scoring system in a recent study. ${ }^{18}$ Another concern is the lack of uniformity of casedefinitions. A strict definition of URTI (ear, nose, throat region) or LRTI (bronchi and lung tissue) is difficult in young children, since classical criteria like tachypnea and hypoxia are not restricted to LRTI.

\section{CONCLUSION}

In conclusion, clinical management and outcome in children with ARI are not determined by the type of virus. Children with one specific virus do not have a specific clinically recognizable pattern and children with singleand multiple viral $A R I$ are clinically indistinguishable. LOS is determined by duration of extra oxygen supply or need for nebulizer therapy. The impact of RT-PCR for special indications is outside the scope of this paper as is the role of RT-PCR for other clinical purposes such as management of cohorting of inhospital patients. However, at this moment, for the general pediatric patient management the impact seems limited. In these settings, RT-PCR assays should be restricted to pathogens for which therapy is available, e.g. the clinical course can be influenced, such as for RSV, FLU and Bordetella pertussis.

\section{ACKNOWLEDGEMENTS}

We thank P. Goswami, MD for critically reviewing the manuscript in the English language. 


\section{REFERENCES}

1. Ralston SL, Lieberthal AS, Meissner HC, Alverson BK, Baley JE, Gadomski AM, et al. Clinical practice guideline: the diagnosis, management, and prevention of bronchiolitis. Pediatrics. 2014; 134:e1474-502.

2. Neuzil KM, Mellen BG, Wright PF, Mitchel Jr EF, Griffin MR. The effect of influenza on hospitalizations, outpatient visits, and courses of antibiotics in children. N Engl J Med. 2000;342:225-31.

3. Bloemers BL, van Furth AM, Weijerman ME, Gemke RJ, Broers CJ, van den Ende K, et al. Down syndrome: a novel risk factor for respiratory syncytial virus bronchiolitis-a prospective birth-cohort study. Pediatrics. 2007;120:e1076-81.

4. Collins PL, Graham BS. Viral and host factors in human respiratory syncytial virus pathogenesis. J Virol. 2008;82:2040-55.

5. Tregoning JS, Schwarze J. Respiratory viral infections in infants: causes, clinical symptoms, virology, and immunology. Clin Microbiol Rev. 2010; 23:74-98.

6. Jartti T, Soderlund-Venermo M, Hedman K, Ruuskanen O, Makela MJ. New molecular virus detection methods and their clinical value in lower respiratory tract infections in children. Paediatr Respir Rev. 2013;14:38-45.

7. Brand HK, de Groot R, Galama JM, Brouwer ML, Teuwen K, Hermans PW, et al. Infection with multiple viruses is not associated with increased disease severity in children with bronchiolitis. Pediatr Pulmonol. 2012;47:393-400.

8. Martin ET, Kuypers J, Wald A, Englund JA. Multiple versus single virus respiratory infections: viral load and clinical disease severity in hospitalized children. Influenza Other Respi Viruses. 2012;6:71-7.

9. Martinez P, Cordero J, Valverde C, Unanue N, Dalmazzo R, Piemonte P, et al. Viral respiratory co-infections in pediatric patients admitted for acute respiratory infection and their impact on clinical severity. Rev Chilena Infectol. 2012;29:169-74.

10. Ricart S, Marcos MA, Sarda M, Anton A, Munoz-Almagro C, Pumarola T, et al. Clinical risk factors are more relevant than respiratory viruses in predicting bronchiolitis severity. Pediatr Pulmonol. 2013;48(5):456-63.

11. Versteegh FGA, Weverling GJ, Peeters MF, Wilbrink B, Veenstra-van Schie MTM, van Leeuwen-Gerritsen JM, et al. Community-acquired pathogens associated with prolonged coughing in children: a prospective cohort study. Clin Microbiol Infect. 2005;11:801-7.

12. Calvo C, Garcia-Garcia ML, Blanco C, Vazquez MC, Frias ME, Perez-Brena P, et al. Multiple simultaneous viral infections in infants with acute respiratory tract infections in Spain. J Clin Virol. 2008;42:268-72.

13. Semple MG, Cowell A, Dove W, Greensill J, McNamara PS, Halfhide C, et al. Dual infection of infants by human metapneumovirus and human respiratory syncytial virus is strongly associated with severe bronchiolitis. J Infect Dis. 2005;191:382-6.

14. Bekhof J, Bakker J, Reimink R, Wessels M, Langenhorst V, Brand PLP, et al. Co-infections in children hospitalised for bronchiolitis: role of roomsharing. J Clin Med Res. 2013;5:426-31.

15. Wishaupt JO, Russcher A, Smeets LC, Versteegh FGA, Hartwig NG. Clinical impact of RT-PCR for pediatric acute respiratory infections: a controlled clinical trial. Pediatrics. 2011;128:e1113-20.

16. Fleming S, Thompson M, Stevens R, Heneghan C, Pluddemann A, Maconochie I, et al. Normal ranges of heart rate and respiratory rate in children from birth to 18 years of age: a systematic review of observational studies. Lancet. 2011;377:1011-8. 
17. Gern JE, Martin MS, Anklam KA, Shen K, Roberg KA, Carlson-Dakes KT, et al. Relationships among specific viral pathogens, virus-induced interleukin-8, and respiratory symptoms in infancy. Pediatr Allergy Immunol. 2002;13:386-93.

18. Wishaupt JO, van den Berg EAN, van Wijk T, van der Ploeg T, Versteegh FGA, Hartwig NG. Paediatric apnoeas are not related to a specific respiratory virus, and parental reports predict hospitalisation. Acta Paediatr. 2016;105:542-8.

19. van den Brink G, Wishaupt JO, Douma JC, Hartwig NG, Versteegh FGA. Bordetella pertussis: an underreported pathogen in pediatric respiratory infections, a prospective cohort study. BMC Infect Dis. 2014;14:526. 20. Nair H, Nokes DJ, Gessner BD, Dherani M, Madhi SA, Singleton RJ, et al.

20. Nair H, Nokes DJ, Gessner BD, Dherani M, Madhi SA, Singleton RJ, et al. Global burden of acute lower respiratory infections due to respiratory syncytial virus in young children: a systematic review and meta-analysis. Lancet. 2010;375:1545-55.

21. Morikawa S, Kohdera U, Hosaka T, Ishii K, Akagawa S, Hiroi S, et al. Seasonal variations of respiratory viruses and etiology of human rhinovirus infection in children. J Clin Virol. 2015;73:14-9.

22. Korppi M, Kotaniemi-Syrjanen A, Waris M, Vainionpaa R, Reijonen TM. Rhinovirus-associated wheezing in infancy: comparison with respiratory syncytial virus bronchiolitis. Pediatr Infect Dis J. 2004;23:995-9.

23. Papadopoulos NG, Moustaki M, Tsolia M, Bossios A, Astra E, Prezerakou A, et al. Association of rhinovirus infection with increased disease severity in acute bronchiolitis. Am J Respir Crit Care Med. 2002;165:1285-9.

24. Van Leeuwen JC, Goossens LK, Hendrix RM, Van Der Palen J, Lusthusz A, Thio BJ. Equal virulence of rhinovirus and respiratory syncytial virus in infants hospitalized for lower respiratory tract infection. Pediatr Infect Dis J. 2012;31:84-6.

25. van den Hoogen BG, Osterhaus ADME, Fouchier RAM. Clinical impact and diagnosis of human metapneumovirus infection. Pediatr Infect Dis J. 2004; 23:S25-32.

26. Milder E, Arnold JC. Human metapneumovirus and human bocavirus in children. Pediatr Res. 2009;65:78R-83R.

27. Wutzler P, Schmidt-Ott R, Hoyer H, Sauerbrei A. Prevalence of influenza A and B antibodies in pregnant women and their offspring. J Clin Virol. 2009; 46:161-4.

28. Mancinelli L, Onori M, Concato C, Sorge R, Chiavelli S, Coltella L, et al. Clinical features of children hospitalized with influenza A and B infections during the 2012-2013 influenza season in Italy. BMC Infect Dis. 2016;16:6.

29. Moesker FM, van Kampen JJ, van der Eijk AA, van Rossum AM, de Hoog M, Schutten M, et al. Human bocavirus infection as a cause of severe acute respiratory tract infection in children. Clin Microbiol Infect. 2015;21:964-8.

30. Jartti T, Hedman K, Jartti L, Ruuskanen O, Allander T, Soderlund-Venermo M. Human bocavirus-the first 5 years. Rev Med Virol. 2012;22:46-64.

31. Ralston S, Hill V. Incidence of apnea in infants hospitalized with respiratory syncytial virus bronchiolitis: a systematic review. J Pediatr. 2009;155:728-33.

32. Peng D, Zhao D, LIU J, Wang X, Yang $K$, Xicheng $H$, et al. Multipathogen infections in hospitalized children with acute respiratory infections. Virol J. 2009;6:155. 
33. Koopman LP, Smit HA, Heijnen ML, Wijga A, van Strien RT, Kerkhof M, et al. Respiratory infections in infants: interaction of parental allergy, child care, and siblings- The PIAMA study. Pediatrics. 2001;108:943-8.

34. Ochoa SC, Barajas Sanchez MV, Munoz MB. Relationship between child day-care attendance and acute infectious disease. A systematic review. Rev Esp Salud Publica. 2007;81:113-29.

35. Linder JE, Kraft DC, Mohamed Y, Lu Z, Heil L, Tollefson S, et al. Human rhinovirus C: Age, season, and lower respiratory illness over the past 3 decades. J Allergy Clin Immunol. 2013;131:69-77.

36. Xiao Q, Zheng S, Zhou L, Ren L, Xie X, Deng Y, et al. Impact of human rhinovirus types and viral load on the severity of illness in hospitalized children with lower respiratory tract infections. Pediatr Infect Dis J. 2015;34:1187-92.

37. Fodha I, Vabret A, Ghedira L, Seboui H, Chouchane S, Dewar J, et al. Respiratory syncytial virus infections in hospitalized infants: association between viral load, virus subgroup, and disease severity. J Med Virol. 2007; 79:1951-8.

38. Houben ML, Coenjaerts FE, Rossen JW, Belderbos ME, Hofland RW, Kimpen JL, et al. Disease severity and viral load are correlated in infants with primary respiratory syncytial virus infection in the community. J Med Virol. 2010;82:1266-71. 


\section{SUPPLEMENTARY INFORMATION}

Supplementary Table 1. Modified disease severity score after Gern ${ }^{17,} 18$

\begin{tabular}{lc}
\hline Symptom & point score $^{\mathbf{a}}$ \\
\hline Fever & 1 \\
Cough & 1 \\
Rhinorrhea & 1 \\
Duration of illness $>$ days & 1 \\
Apnea & 3 \\
Wheezing & 5 \\
Hypoxia & 5 \\
Retractions & 5 \\
Tachypnea & 5 \\
\hline
\end{tabular}

a maximum score is 27 


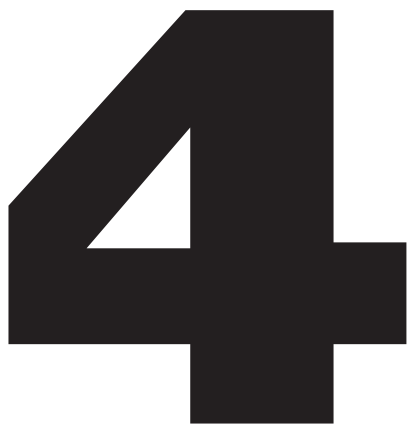


PAEDIATRIC APNOEAS ARE NOT RELATED TO A SPECIFIC RESPIRATORY VIRUS, AND PARENTAL REPORTS PREDICT HOSPITALISATION

Jérôme O. Wishaupt, Esther A.N. van den Berg, Tessa van Wijk, Tjeerd van der Ploeg, Florens G.A. Versteegh and Nico G. Hartwig

Acta Paediatrica 2016 May; 105(5):542-8 


\section{ABSTRACT}

\section{Aim}

The aim of this study was to determine the frequency of apnoeas in previously healthy young infants with acute respiratory tract infection (ARI) and correlate their occurrence with isolated micro-organisms, clinical findings, disease severity and outcome.

\section{Methods}

We performed reverse transcriptase real-time polymerase chain reaction (RT-PCR) on the nasal wash specimens of a prospective cohort study of 582 children with ARI. Clinical data on a subgroup of 241 infants under three months of age, with and without apnoeas, were compared.

\section{Results}

Our study found that 19 (7.9\%) of the 241 infants under three months old had a history of apnoeas: eight had a respiratory syncytial virus (RSV), five had a different virus than RSV and seven RT-PCR results were negative. Infants with apnoeas were more likely to have cyanosis, had longer hospital stays and required extra oxygen for a longer period. Most patients with parental reported apnoeas also experienced apnoeas during hospitalisation.

\section{Conclusion}

This study observed apnoeas irrespective of the isolated micro-organism, and we hypothesise that they were related to the pathophysiology of the respiratory infection and not to the micro-organism itself. Parental reported apnoeas were a major warning sign and predicted that apnoeas would occur in hospital.

\section{Key notes}

This study of previously healthy young infants under three months of age with acute respiratory tract infections found that 19/241 (7.9\%) had a history of apnoeas.

We observed apnoeas irrespective of the isolated micro-organism and hypothesise that they were related to the pathophysiology of the respiratory infection and not to the micro-organism itself.

Parental reported apnoeas were a major warning sign and predicted that apnoeas would occur in hospital.

\section{Keywords}

Acute respiratory tract infection, Apnoea, Child, Respiratory arrest, Respiratory syncytial virus 


\section{INTRODUCTION}

Acute respiratory tract infection (ARI) is the leading cause of hospitalisation in young children ${ }^{1}$, and the respiratory syncytial virus (RSV) is responsible for approximately $45-80 \%$ of those admissions, depending on the season. Since 1970s, RSVs have been recognised as the key organism associated with apnoeas. ${ }^{2,3}$ In paediatric intensive care unit (PICU) settings, these RSV infections often require mechanical ventilation, but resolve within the days of onset. ${ }^{4}$

Apnoeas are characterised by the absence of airflow, and their pathophysiology is diverse and comprises several mechanisms. Some researchers have suggested that the infant's immature brainstem respiratory centre plays a role, and an exaggerated inhibitory response leads to reduced breathing effort.5,6 A second proposed mechanism was related to the infectious status of the respiratory system, regardless of the causative organism. In a prospective study, respiratory arrest was associated with a strong inflammatory response in the mucosa. ${ }^{7} \mathrm{~A}$ third proposed mechanism referred to the stimulation of stretch receptors in the lungs, causing a reflectory negative feedback to respiration, known as the Hering-Breuer reflex. ${ }^{8-10}$ This reflex is sometimes stronger due to general malaise and muscle fatigue. ${ }^{11-13} \mathrm{~A}$ fourth proposed mechanism was an obstruction of the airways by mucus plugging and stasis in the nose and, or, small airways. Obstructive apnoeas may also lead to subsequent central apnoeas. ${ }^{10}$ In the literature, apnoeas have been strongly associated with RSV, and they may be the first sign of disease. ${ }^{14,15}$ However, since the introduction of real-time reverse transcriptase polymerase chain reaction (RT-PCR) in general practice, more viruses have also been associated with apnoeas. 2,15-20

Studies have consistently maintained that the major risk factors for the development of ARI-related apnoeas are prematurity, an early postnatal onset at less than two months of age and a history of apnoea or cyanosis and comorbidity, especially of the respiratory tract. $2,4,5,14,21,22$

However, it is not known what effect the individual viruses have on apnoeas. So far, researchers have suggested that RSV is the most important virus, based on frequency. But perhaps we need to broaden our scope to include other viruses as well. This study aimed to answer two clinical questions: is it just RSV infected infants that need hospitalisation based on the risk of apnoeas and which parameters add to clinical decision-making regarding the need for hospital admission? To answer these questions, we studied the incidence of apnoeas and clinical characteristics in formerly healthy infants presenting with respiratory symptoms to their paediatrician.

\section{METHODS}

\section{Patients and study design}

This study was a substudy of the Evaluation of Viral Diagnostics on Respiratory Infections in Children (EVIDENCE) trial, a multicentre randomised clinical trial 
designed to evaluate the clinical impact of rapidly communicating RT-PCR results to paediatricians who saw paediatric patients who presented with acute respiratory symptoms. The study comprises 582 previously healthy children from 0 to 12 years of age. The study protocol has already been described elsewhere. ${ }^{19}$ The research was conducted during two winter seasons at two hospitals in the Netherlands, the Reinier de Graaf Hospital in Delft and the Groene Hart Ziekenhuis in Gouda, between November 2007 and May 2008 and October 2008 and March 2009. The inclusion criteria were children with respiratory symptoms and suspected ARIs in the two hospitals' emergency departments, outpatient clinics and paediatric wards. Most of the children were referred to the hospitals after initial assessments by their primary care physicians, which is a common practice in the Netherlands. We excluded children with underlying anatomical airway abnormalities, neuromuscular impairment or other significant underlying disorders, such as syndromal disorders that included psychomotor retardation, malignancies and cardiac pathology. All newborn infants hospitalised since birth were also excluded. No restrictions were placed on including patients with asthma or suspected asthma.

To analyse the incidence and clinical characteristics of the children with apnoeas, we only selected infants who were younger than three months from the EVIDENCE data set, because the risk of apnoeas is highest in this age group. ${ }^{2,14,21}$

The regional medical ethics committee approved the trial protocol, and all parents provided written, informed consent.

\section{Data collection and nasal wash specimens}

Clinical data were prospectively collected using a standardised form, and missing data, as well as laboratory and radiologic reports, were retrieved from the hospitals' medical records.

In addition to the standard hospital protocols, RT-PCR assays for 15 viruses and two bacteria were performed on all nasal wash specimens (Supplementary Table 1). Bordetella pertussis was only tested if there was a clinical suspicion. Duplex RT-PCR assays were performed with all nasal wash specimens using assays developed in-house. The RT-PCR method and validation procedure have already been described elsewhere. ${ }^{19}$

\section{Definitions}

Apnoea was defined as one or more episodes of respiratory pauses, regardless of duration, that were observed by parents or guardians, physicians or nurses and resulted in hospitalisation. During hospitalisation, the definition of apnoea agreed by the American Academy of Pediatrics was used: an unexplained episode of cessation of breathing for 20 seconds or longer or a shorter respiratory pause associated with bradycardia, cyanosis, pallor and, or, marked hypotonia. ${ }^{23}$

The disease severity score (DSS) used in this study, which was designed to determine the severity of the respiratory illness, was a modification of the severity 
score developed by Gern et al. ${ }^{24}$ A score of zero to seven represented mild disease, while 8-18 indicated moderate disease and 19-27 indicated severe disease (Supplementary Table 2).

\section{Statistical analysis}

The statistical package SPSS version 18.0 was used to analyse the data (SPSS Inc, Chicago, USA). Categorical variables were compared using Pearson's chi-square test or Fisher's exact test, and the Mann-Whitney U-test was used for continuous variables. To present the risk factors for apnoea, the odds ratio (OR) and 95\% confidence interval $(95 \% \mathrm{Cl})$ were calculated from two-by-two tables. When the $95 \% \mathrm{Cl}$ included one, no significant association between a risk factor and apnoea existed. Statistical significance was defined as $p<0.05$.

\section{RESULTS}

A total of 241 infants under three months of age were included in this analysis, and $19(7.9 \%)$ had apnoeas during the course of their disease. We divided the 241 infants into two groups based on the presence $(n=19)$ or absence $(n=222)$ of apnoeas (Table 1). Both groups were comparable with regard to gender, gestational age and birth weight, but the apnoea group tended to be younger at presentation: 10 infants with apnoeas (52.6\%) were younger than one month at the time of diagnosis. Only two patients with apnoeas were older than three months. These two infants both were born after full-term delivery, both experienced apnoeas as result of gastrooesophageal reflux disease, and they were not included in this analysis.

Of the 19 apnoeic episodes, 17 were reported by the parents or guardians before admission to the hospital, and the other two were not reported and occurred during hospitalisation when the infants were monitored for vital signs using a cardiorespiratory monitor (Table 1). One infant with a parent reported apnoea, and a DSS of 11, was not admitted to the hospital because of their excellent clinical condition after a short observation period in the outpatient clinic. The remaining 18 infants were hospitalised, and 12 of them also experienced apnoeas during hospitalisation, just like they did at home.

Infants with apnoeas had a significantly longer duration of hospitalisation, received more oxygen and presented with cyanosis more frequently (Table 1). The median DSS was significantly higher in infants with, than without, apnoeas: 15.0 compared to 8.0 $(p=0.006)$. As apnoea itself was included in the DSS, we recalculated the difference between the apnoea and nonapnoea groups after excluding apnoea from the DSS. As shown in Table 1, once this was performed, the DSS lost its significance.

Four infants $(21.1 \%)$ in the apnoea group were eventually admitted to a PICU, compared to none in the nonapnoea group $(p<0.001)$, and the median DSS of the infants admitted to the PICU was 26.5. 
Table 1. Patient characteristics and clinical findings in the apnoea and non-apnoea groups

\begin{tabular}{|c|c|c|c|}
\hline & $\begin{array}{l}\text { Apnoea } \\
\mathrm{n}=19\end{array}$ & $\begin{array}{l}\text { No apnoea } \\
n=222\end{array}$ & p value \\
\hline \multicolumn{4}{|l|}{ Patient demographics } \\
\hline Male, $\mathrm{n}(\%)$ & $9(47.4)$ & $129(58.1)$ & $0.364^{+}$ \\
\hline Gestational age $\leq 35$ weeks, $\mathrm{n}(\%)$ & $3(15.8)$ & $13(5.9)$ & $0.120^{\ddagger}$ \\
\hline Birth weight, median (g) & $\begin{array}{l}n=16 \\
3,070.0\end{array}$ & $\begin{array}{l}n=136 \\
3,537.5\end{array}$ & $0.184^{*}$ \\
\hline Age at diagnosis, median (months) & 0.95 & 1.44 & $0.065^{*}$ \\
\hline \multicolumn{4}{|l|}{ Time course of apnoeas } \\
\hline Before admission, n/total infants (\%) & $17 / 19(89)$ & $0(0)$ & $<0.001^{\dagger}$ \\
\hline During hospitalisation, n/hospitalised (\%) & $12 / 18(67)$ & $0(0)$ & $<0.001^{+}$ \\
\hline Continuous monitoring of vital signs, $\mathrm{n}(\%)$ & $18(100)$ & $158(94)$ & $0.287^{+}$ \\
\hline \multicolumn{4}{|l|}{ Findings at admission } \\
\hline Disease severity score (DSS), median & 15.00 & 8.00 & $0.006^{*}$ \\
\hline \multicolumn{4}{|l|}{ DSS Categories, $\mathrm{n}(\%)$} \\
\hline$<=7$ / reference & $3(15.8)$ & $108(48.6)$ & $0.022^{+}$ \\
\hline $8-18$ & $11(57.9)$ & $80(36.0)$ & \\
\hline $19+$ & $5(12.8)$ & $34(15.3)$ & \\
\hline Presence of fever, $n(\%)$ & $5(26.3)$ & $70(31.5)$ & $0.637^{+}$ \\
\hline Presence of wheezing, $n(\%)$ & $6(31.6)$ & $50(22.5)$ & $0.398^{\ddagger}$ \\
\hline Presence of cough, $\mathrm{n}(\%)$ & $13(68.4)$ & $152(68.5)$ & $0.997^{+}$ \\
\hline Presence of rhinorrhoea, $\mathrm{n}(\%)$ & $15(89.6)$ & $199(78.9)$ & $0.243^{\ddagger}$ \\
\hline Presence of cyanosis, $\mathrm{n}(\%)$ & $14(73.7)$ & $77(34.7)$ & $0.001^{+}$ \\
\hline Presence of tachypnoea, $\mathrm{n}(\%)$ & $6(31.6)$ & $96(43.2)$ & $0.323^{+}$ \\
\hline Presence of retractions, n(\%) & $9(47.4)$ & $90(40.5)$ & $0.562^{+}$ \\
\hline DSS without apnoea, median & 11.00 & 8.00 & $0.271^{*}$ \\
\hline \multicolumn{4}{|l|}{ Hospitalization and disease course } \\
\hline Hospitalisation, $\mathrm{n}(\%)$ & $18(94.7)$ & $168(75.7)$ & $0.057^{+}$ \\
\hline Duration of hospitalization, median (days) & 6.00 & 3.00 & $0.003^{*}$ \\
\hline PICU admission, $n(\%)$ & $4(21.1)$ & $0(0)$ & $<0.001^{\ddagger}$ \\
\hline Duration of extra oxygen use, median (days) & $\begin{array}{l}n=18 \\
3.00\end{array}$ & $\begin{array}{l}n=168 \\
\mathbf{0 . 0 0}\end{array}$ & $0.003^{*}$ \\
\hline
\end{tabular}

Significant differences are noted as bold. DSS, disease severity score; PICU, paediatric intensive care unit. *For continuous variables, Mann-Whitney $U$ tests were used. †For categorical variables, chi-square tests were used.

${ }^{\ddagger}$ For categorical variables, Fisher's exact test was used because of expected frequencies less than five.

In addition to Table 1, the clinical data of each of the 19 patients with apnoeas are presented in Table 2. These include descriptions of the apnoeas, length and frequency of pauses, degree of oxygen desaturation, heart rate changes and interventions required to treat the hypoxia, when available.

The RT-PCT test was negative in seven infants (36.8\%) in the apnoea group, compared with $53(23.0 \%)$ in the nonapnoea group, but this difference was not 


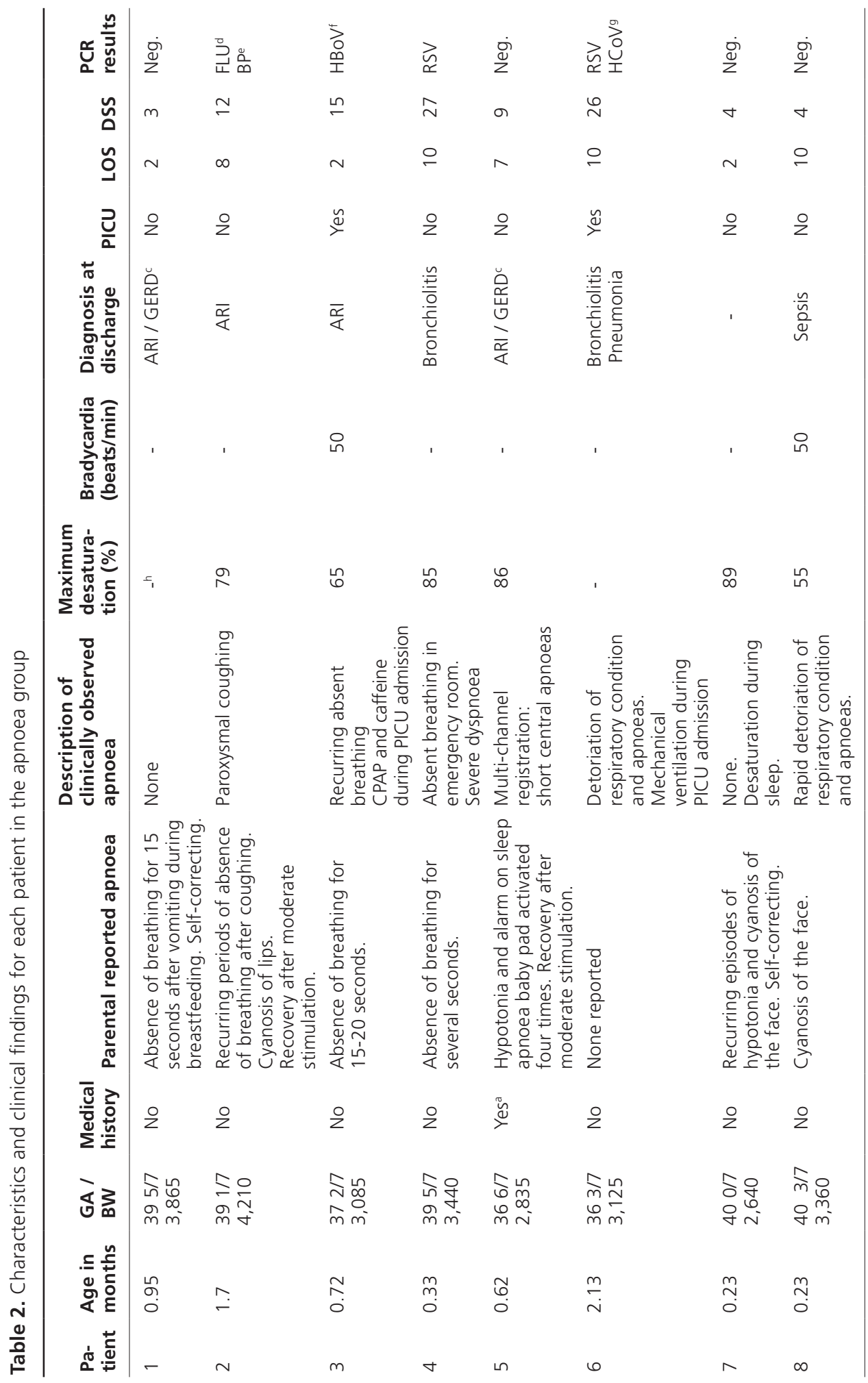




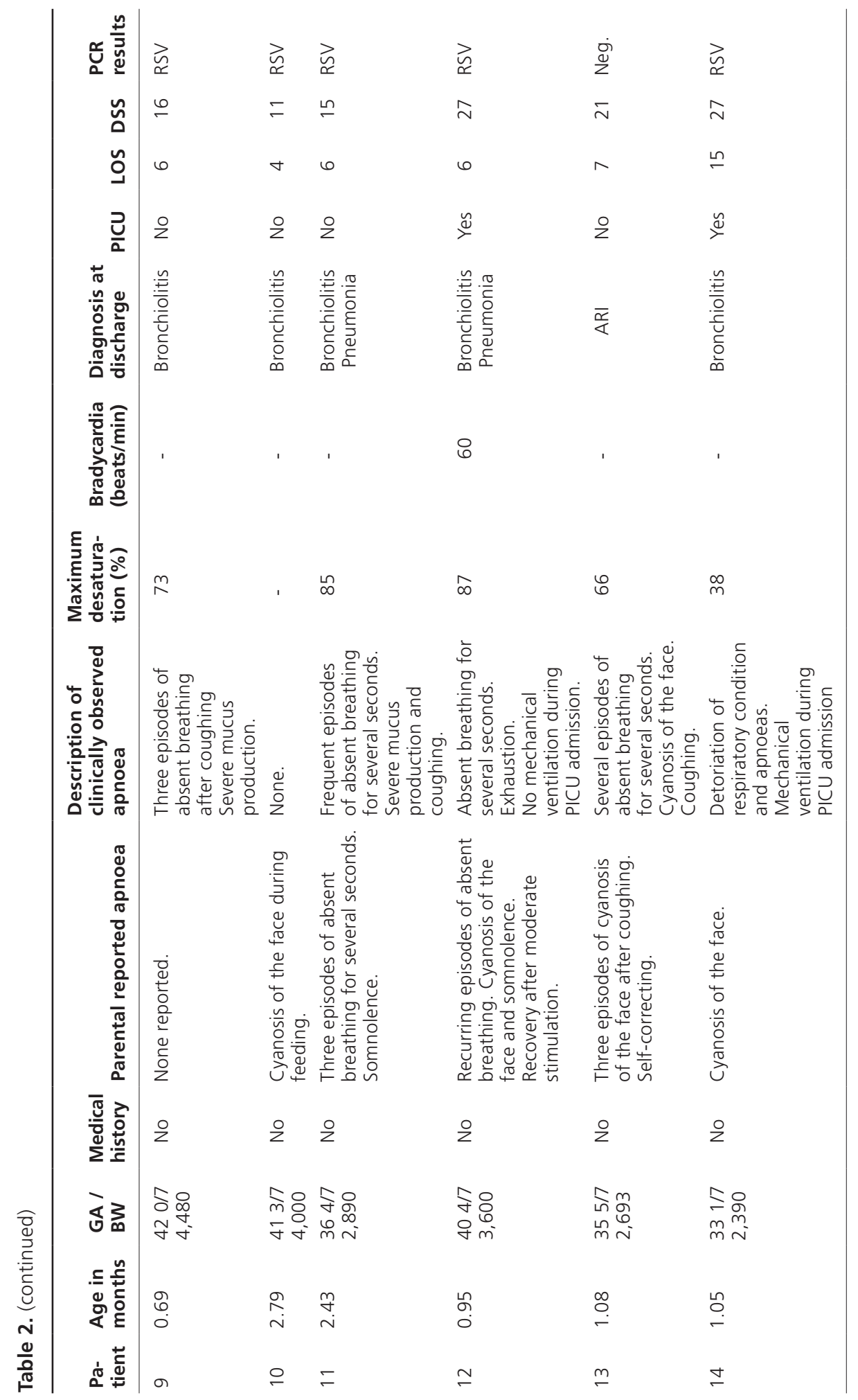




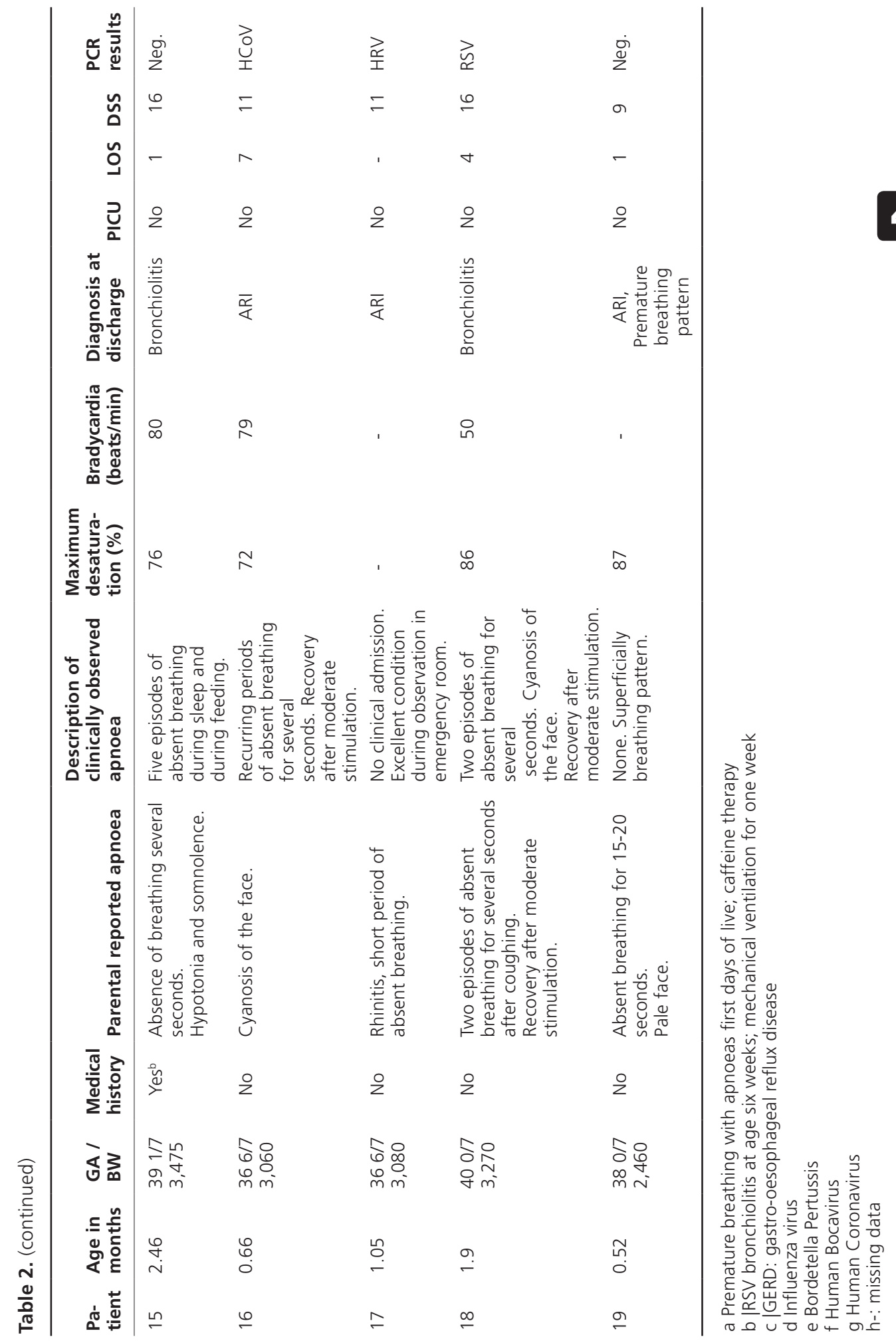


statistically significant (Table 3). In the infants with apnoea, no positive RT-PCR tests for adenovirus, human metapneumovirus and parainfluenza virus were found, whereas those viruses were often present in the nonapnoea group. The percentage of RSV as the causative agent for ARI was equal in both groups. One infant in the subgroup with apnoeas was positive for the influenza virus as well as for Bordetella pertussis. In the other infants, only a single virus was detected. RT-PCR detected either two or three viruses in 38 infants (17.1\%) in the nonapnoea group.

Although the detected viruses did not differ significantly between both groups, it is evident that non RSV viruses also led to apnoeas. The percentage of apnoeas in the different PCR groups is shown in Table 4.

Table 3. Laboratory findings in the apnoea and non-apnoea groups

\begin{tabular}{|c|c|c|c|}
\hline & $\begin{array}{l}\text { Apnoea } \\
n=19\end{array}$ & $\begin{array}{l}\text { No apnoea } \\
\mathrm{n}=222\end{array}$ & p value \\
\hline \multicolumn{4}{|l|}{ Viruses* } \\
\hline Adenovirus, $\mathrm{n}(\%)$ & $0(0)$ & $5(2.3)$ & N/A \\
\hline Human bocavirus, n(\%) & $1(5.3)$ & $1(0.45)$ & $0.152^{+}$ \\
\hline Human coronavirus, $\mathrm{n}(\%)$ & $2(10.5)$ & $26(11.7)$ & $1.000^{+}$ \\
\hline Human metapneumovirus, n(\%) & $0(0)$ & $16(7.2)$ & N/A \\
\hline Influenzavirus, n(\%) & $1(5.3)$ & $19(8.6)$ & $1.000^{+}$ \\
\hline Negative, $\mathrm{n}(\%)$ & $7(36.8)$ & $53(23.9)$ & $0.267^{+}$ \\
\hline Parainfluenzavirus, n(\%) & $0(0)$ & $9(4.1)$ & N/A \\
\hline Rhinovirus, $\mathrm{n}(\%)$ & $1(5.3)$ & $30(13.5)$ & $0.481^{\dagger}$ \\
\hline Respiratory syncytial virus, n(\%) & $8(42.1)$ & $100(45.0)$ & $1.000^{+}$ \\
\hline \multicolumn{4}{|l|}{ Other findings } \\
\hline Bordetella pertussis, $\mathrm{n}(\%)$ & $1(5.3)$ & $0(0)$ & N/A \\
\hline Chlamydophila pneumonia, n(\%) & $0(0)$ & $1(0.45)$ & N/A \\
\hline Mycoplasma pneumonia, n(\%) & $0(0)$ & $4(1.8)$ & N/A \\
\hline
\end{tabular}

* Total proportions exceed $100 \%$ because pathogens in mixed infections were also counted individually.

${ }^{\dagger}$ For categorical variables, Fisher's exact test was used because of expected frequencies less than five.

Abbreviations: N/A, not applicable.

Table 4. Percentage of apnoeas in the different PCR groups

\begin{tabular}{ll}
\hline PCR result & percentage apnoeas $(\mathbf{n} / \mathbf{N})$ \\
\hline RSV & $7.4 \%(8 / 108)$ \\
Non-RSV & $7.0 \%(12 / 171)$ \\
Other virus than RSV identified & $4.5 \%(5 / 111)$ \\
No virus identified & $11.7 \%(7 / 60)$ \\
\hline
\end{tabular}




\section{DISCUSSION}

Our data show that apnoeas are not just caused by RSV. These findings are in line with the recent publications that suggested that apnoeas result from general inflammatory responses, rather than from a specific microorganism. ${ }^{7}$ In our study, parental reports of apnoeas at home significantly predicted apnoeas in the hospital. Another study has published similar risk factors. ${ }^{20}$

Most studies on apnoeas have primarily focused on the relationship with RSV. Epidemics occur each winter that lead to many young infants under the age of three months being hospitalised. The high frequency of RSV infections is probably responsible for the idea that RSV itself induces apnoeas. As RSV is highly associated with apnoeas, ${ }^{2,3}$ several guidelines recommend hospitalising young infants with an RSV infection even if there are no clinical signs that warrant hospital care. ${ }^{25}$ In contrast to these recommendations, our study revealed that the same proportion of apnoeas was also observed in nonRSV infections and that they occurred irrespective of the causative micro-organism.

We could not find a statistically significant difference between apnoeas and any specific virus, but our sample size was probably too small to answer that question. Our findings were in line with a prospective multicentre study that demonstrated a similar apnoea risk across the major viral pathogens. ${ }^{20}$

Definitions of apnoea differ in the literature, ${ }^{23,26}$ and this makes it difficult to determine their incidence accurately. To compare our study with the literature, we focused on apnoeas at home, namely a parental reported history of respiratory arrest at home, in common with most of the other researchers. ${ }^{15} \mathrm{~A}$ minimum duration of the respiratory arrest was not included in this definition. Most infants with ARIassociated apnoeas receive their care in a general hospital. As a result, the registration of apnoeas during hospitalisation in our study was less accurate than in a PICU setting and was probably under-reported. Furthermore, the phenomenon of apnoea remains a subjective observation when it is not measured with close monitoring of vital parameters, breathing patterns and airflow. Despite these issues, our results stress that parental observations of apnoeas should be taken seriously and are a strong predictor of apnoeas in hospital (Tables 1 and 2).

Young age is an important risk factor for the occurrence of apnoeas. ${ }^{3,4}$ In our initial cohort, 21 (3.5\%) of the 582 children had apnoeas, and only two of these were older than three months. This incidence in the initial cohort, or 19/241 (7.9\%) in the age-restricted group, corresponded to the results described in a review, in which the overall apnoea rate ranged from $1.2 \%$ to $23.8 \% .{ }^{15}$ The variations in incidence detected by this review were the result of different definitions of apnoea and the age ranges that were included.

When we refer to the possible mechanisms of apnoeas, young age is likely to be associated with immaturity of the brainstem respiratory centre and is likely to partly 
contribute to the ccurrence of apnoeas. ${ }^{6,27,28}$ The correlation of apnoeas with the DSS supports the view that the inflammatory reaction itself is an important factor when it comes to increasing the risk of apnoeas. ${ }^{7}$ Activation of the laryngeal chemoreceptors by inflammatory cytokines leads to prolonged respiratory arrest between two breaths, ${ }^{6}$ and this view is further supported by the observation that apnoeas mainly occur in children with an involvement of the lower respiratory tract. These are both situations in which hypoxia and hypercapnia are more likely to occur. However, the inflammatory response is only partly responsible, because the significance of the DSS decreased after excluding apnoea from the scoring system. Without extensive breathing registration, it is not possible to establish the relative contribution of the brainstem respiratory centre and the inflammatory status. Four of the infants with apnoea in our study were only diagnosed with an upper respiratory tract infection, and one of these infants suffered from choking periods due to nasal obstruction. As young children obligatory breathe through their nose, ${ }^{29}$ apnoeas may occur without lower respiratory tract involvement. Excessive mucus production or plugging in these children causes mechanical airway blockage that can easily be resolved by rinsing the nose with saline or using suction or decongestive medication.

Apnoeas predicted a more unfavourable clinical course. Four of the 19 nineteen (21\%) infants in our study were eventually admitted to a PICU due to respiratory insufficiency. Although the DSS in our study was not validated to predict PICU admittance, the scores of the infants admitted to the PICU were significantly higher than those who stayed on a paediatric ward. A retrospective study of 43 RSV positive patients who were admitted to a PICU for apnoeas found that the risk factors were younger age, lower admission weight, lower gestational age, admission from the emergency room and the lack of hyperthermia. ${ }^{30}$ From a clinical point of view, it would be helpful if the DSS could predict which infants with apnoeas required PICU care.

\section{CONCLUSION}

Apnoeas were observed in about $7 \%$ of infants with ARIs under the age of three months, irrespective of the isolated micro-organism. The most likely causes were general inflammatory responses, an immature brainstem or blocked nose. Viral testing for an RSV should not be used to identify infants who need to be hospitalised. The only parameter that significantly predicted the occurrence of apnoeas during hospital admission in our study was parental reports of apnoeas at home. 


\section{REFERENCES}

1. Yorita KL, Holman RC, Sejvar JJ, Steiner CA, Schonberger LB. Infectious disease hospitalizations among infants in the United States. Pediatrics 2008; 121: 244-52.

2. Bruhn FW, Mokrohisky ST, Mclntosh K. Apnoea associated with respiratory syncytial virus infection in young infants. J Pediatr 1977; 90: 382-6.

3. Church NR, Anas NG, Hall CB, Brooks JG. Respiratory syncytial virus-related apnoea in infants. Demographics and outcome. Am J Dis Child 1984; 138: 247-50.

4. Anas N, Boettrich C, Hall CB, Brooks JG. The association of apnoea and respiratory syncytial virus infection in infants. J Pediatr 1982; 101: 65-8.

5. Simoes EA. Respiratory syncytial virus infection. Lancet 1999; 4: 847-52.

6. Thach BT. Some aspects of clinical relevance in the maturation of respiratory control in infants. J Appl Physiol 2008; 104: 1828-34.

7. Gleeson M, Clancy RL, Cox AJ, Gulliver SA, Hall ST, Cooper DM. Mucosal immune responses to infections in infants with acute life threatening events classified as 'near-miss' sudden infant death syndrome. FEMS Immunol Med Microbiol 2004; 1: 105-18.

8. Hannam S, Ingram DM, Milner AD. A possible role for the Hering-Breuer deflation reflex in apnoea of prematurity. J Pediatr 1998; 132: 35-9.

9. Thach BT, Stark AR. Spontaneous neck flexion and airway obstruction during apneic spells in preterm infants. J Pediatr 1979; 94: 275-81.

10. Versteegh FGA, Martin RJ, Carlo WA, Anderson JV, Bruce EN. Effect of nasal occlusion on transcutaneous PO2 and respiratory stability in preterm infants. In Huch A, Huch R, editors. Continuous Transcutaneous Blood Gas Monitoring - Proceedings of the 2nd International Symposium. New York: Dekker, M.; 1983. pp. 291-300.

11. Givan DC. Physiology of breathing and related pathological processes in infants. Semin Pediatr Neurol 2003; 10: 271-80.

12. Theobald K, Botwinski C, Albanna S, McWilliam P. Apnoea of prematurity: diagnosis, implications for care, and pharmacologic management. Neonatal Netw 2000; 19: 17-24.

13. Muller N, Volgyesi G, Bryan MH, Bryan AC. The consequences of diaphragmatic muscle fatigue in the newborn infant. J Pediatr 1979; 95: 793-7.

14. Kneyber MC, Brandenburg AH, de Groot R, Joosten $\mathrm{KF}$, Rothbarth $\mathrm{PH}$, Ott $\mathrm{A}$, et al. Risk factors for respiratory syncytial virus associated apnoea. Eur J Pediatr 1998; 157: 331-5.

15. Ralston S, Hill V. Incidence of apnoea in infants hospitalized with respiratory syncytial virus bronchiolitis: a systematic review. J Pediatr 2009; 155: 728-33.

16. Al-Kindy HA, Gelinas JF, Hatzakis G, Cote A. Risk factors for extreme events in infants hospitalized for apparent lifethreatening events. J Pediatr 2009; 154: 332-7.

17. Mansbach JM, Piedra PA, Teach SJ, Sullivan AF, Forgey T, Clark S, et al. Prospective multicenter study of viral etiology and hospital length of stay in children with severe bronchiolitis. Arch Pediatr Adolesc Med 2012; 166: 700-6.

18. Ricart S, Rovira N, Garcia-Garcia JJ, Pumarola T, Pons M, Munoz-Almagro C, et al. Frequency of apnoea and respiratory viruses in infants with bronchiolitis. Pediatr Infect Dis J 2014; 2: 988-90.

19. Wishaupt JO, Russcher A, Smeets LC, Versteegh FGA, Hartwig NG. Clinical impact of RTPCR for pediatric acute respiratory infections: a controlled clinical trial. Pediatrics 2011; 128: e1113-20.

20. Schroeder AR, Mansbach JM, Stevenson M, Macias CG, Fisher ES, Barcega B, et al. Apnoea in children hospitalized with bronchiolitis. Pediatrics 2013; 132: e1194-201. 
21. Wang EE, Law BJ, Stephens D. Pediatric Investigators Collaborative Network on Infections in Canada (PICNIC) prospective study of risk factors and outcomes in patients hospitalized with respiratory syncytial viral lower respiratory tract infection. J Pediatr 1995; 126: 212-9.

22. Willwerth BM, Harper MB, Greenes DS. Identifying hospitalized infants who have bronchiolitis and are at high risk for apnoea. Ann Emerg Med 2006; 48: 441-7.

23. Committee on Fetus and Newborn. American Academy of Pediatrics. Apnoea, sudden infant death syndrome, and home monitoring. Pediatrics 2003;111:914-7.

24. Gern JE, Martin MS, Anklam KA, Shen K, Roberg KA, CarlsonDakes KT, et al. Relationships among specific viral pathogens, virus-induced interleukin-8, and respiratory symptoms in infancy. Pediatr Allergy Immunol 2002; 13: 386-93.

25. Nederlandse Vereniging voor Kindergeneeskunde. Richtlijn Bronchiolitis: http://www. nvk.nl/tabid/1558/articleType/ArticleView/articleld/698/default.aspx. 2012. Ref Type: Online Source. Last viewed 2015, September.

26. Consensus Development Panel. National Institutes of Health Consensus Development Conference on Infantile Apnoea and Home Monitoring, Sept 29 to Oct 1, 1986. Pediatrics 1987;79: 292-9.

27. Darnall RA, Ariagno RL, Kinney HC. The late preterm infant and the control of breathing, sleep, and brainstem development: a review. Clin Perinatol 2006; 33: 883-914.

28. Stock C, Teyssier G, Pichot V, Goffaux P, Barthelemy JC, Patural H. Autonomic dysfunction with early respiratory syncytial virusrelated infection. Auton Neurosci 2010; 25: 90-5.

29. Praud JP, Reix P. Upper airways and neonatal respiration. Respir Physiol Neurobiol 2005; 15: 131-41.

30. Schiller O, Levy I, Pollak U, Kadmon G, Nahum E, Schonfeld T. Central apnoeas in infants with bronchiolitis admitted to the paediatric intensive care unit. Acta Paediatr 2011; 100: 216-9. 


\section{SUPPLEMENTARY INFORMATION}

Supplementary Table 1. Microorganisms that were tested in nasal wash specimens

Respiratory syncytial virus $A$ and $B$

Influenza virus $A$ and $B$

Rhinovirus

Parainfluenza virus 1, 2, 3, 4

Adenovirus

Human metapneumovirus

Human bocavirus

Human coronavirus 229E, OC43 and NL 63

Chlamydophila pneumonia

Mycoplasma pneumonia

Bordetella pertussis*

* Bordetella pertussus was only tested in case of clinical suspicion

Supplementary Table 2. Modified disease severity score after Gern et al24

\begin{tabular}{lc}
\hline Symptom & point score* $^{*}$ \\
\hline Fever & 1 \\
Cough & 1 \\
Rhinorrhea & 1 \\
Duration of illness $>4$ days & 1 \\
Apnoea & 3 \\
Wheezing & 5 \\
Cyanosis & 5 \\
Retractions & 5 \\
Tachypnea & 5 \\
\hline
\end{tabular}

* Score 0-7 represents mild disease, 8-18 moderate disease and 19-27 severe disease. 


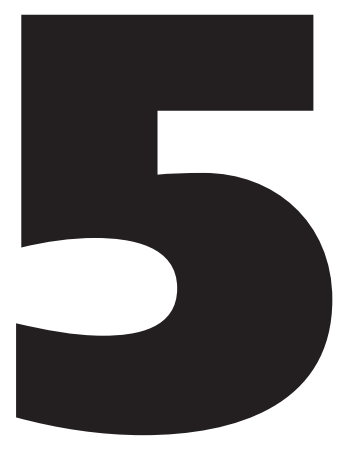




\section{BORDETELLA PERTUSSIS: AN UNDERREPORTED PATHOGEN IN PEDIATRIC RESPIRATORY INFECTIONS, A PROSPECTIVE COHORT STUDY}

Gertrude van den Brink, Jérôme O. Wishaupt, Jacob C. Douma, Nico G. Hartwig and Florens G.A. Versteegh

BMC Infectious Diseases 2014 Sep 30; 14:526 


\section{ABSTRACT \\ Background}

The incidence of pertussis has been increasing worldwide. In the Netherlands, the seroprevalence has risen higher than the reported cases, suggesting that laboratory tests for pertussis are considered infrequently and that even more pertussis cases are missed. The objective of our study was to determine the frequency of pertussis in clinically unsuspect cases compared to suspect cases with the intention of finding clinical predictors.

\section{Methods}

The present prospective cohort study was part of a controlled clinical trial evaluating the impact of molecular diagnostics on clinical decision making in pediatric respiratory infections, performed during 2 winter seasons. For this study, in the first season pertussis was only tested in case of clinical suspicion, in the second season, pertussis was also tested without clinical suspicion. Multivariate and univariate analysis were performed using SPSS 18 and Statistical software ' $R$ '.

\section{Results}

In the two seasons respectively $22 / 209(10,5 \%)$ and $49 / 373(13,1 \%)$ cases were clinically suspected of pertussis. Bordetella pertussis was detected by real time RT-PCR in respectively $2 / 22(9,1 \%)$ and $7 / 49(14,3 \%)$ cases. In the second season an additional 7 cases of pertussis were found in clinically unsuspected cases $(7 / 257=2,7 \%)$. These additional cases didn't differ in clinical presentation from children without a positive test for pertussis with respect to respiratory symptoms.

\section{Conclusions}

Pertussis in children sometimes mimics viral respiratory tract infections. If pertussis diagnostics are based on clinical suspicion alone, about 1 in 5 cases (19\%) is missed. Despite widely accepted clinical criteria, paroxysmal cough is not a good predictor of pertussis. To prevent spreading, physicians should include Bordetella pertussis in routine diagnostics in respiratory tract infections.

\section{Keywords}

Bordetella pertussis, Whooping cough, Respiratory tract infections, Polymerase chain reaction, Child 


\section{BACKGROUND}

Currently, an increase in reported cases of pertussis is noted in many countries, even in countries with high vaccination coverage..$^{1,2}$ However, a higher rise in seroprevalence is observed in relation to reported cases. ${ }^{3}$ From this study one may conclude that cases of pertussis are missed. A possible explanation for this is the wide clinical spectrum of pertussis, ranging from a classical presentation with severe disease and paroxysmal cough to mild disease with only rhinitis. Life threatening disease with apneas is usually restricted to young infants that have not been (fully) immunized. The classic presentation of pertussis is well-known, but is observed less often since start of immunization. Not only immunization, but also previous infection may lead to atypical (mild) pertussis disease which is often not recognized. 2,4,5 These atypical cases are held responsible for ongoing transmission within the population. 4,6

Respiratory (co-) infections may complicate a correct clinical diagnosis of B. pertussis infection. Several studies show that clinical presentation of pertussis is indistinguishable from viral respiratory infections and that co-infection with pertussis exists. ${ }^{4,-9}$ Considering the heterogenic clinical picture of $B$. pertussis infections, the diagnosis cannot solely be made on clinical criteria. Despite this, not all countries apply laboratory tests but rely on WHO case definitions of pertussis. ${ }^{10}$ To control the spread of pertussis within the general population more frequent laboratory confirmation should be advocated. 7.11

Since pertussis may mimic a viral respiratory infection and present without classic symptoms, cases of pertussis are probably not recognized. The frequency of missed diagnosis is not known. Therefore, we conducted a study during two winter seasons in pediatric patients presenting with an acute respiratory tract infection (ARI). We assessed the frequency of pertussis in clinical suspected and unsuspected cases. Our primary goal was to determine the frequency of $B$. pertussis cases in the group of unsuspected children in relation to the group of clinically suspected children and to determine clinical predictors of $B$. pertussis infection in young children.

\section{METHODS \\ Study design}

This prospective cohort study originated in the EVIDENCE-trial (Evaluation of Viral Diagnostics on Respiratory Infections in Children) which was designed as a multicenter, controlled, clinical trial to evaluate the impact of real-time reversed transcriptase polymerase chain reaction (RT- PCR) diagnostics in pediatric patients with ARI. ARI was defined as a new episode of respiratory symptoms of the upper and/or lower airways. The study protocol and definitions has been described before and will be summarized below. ${ }^{12}$ The trial was conducted during 2 consecutive winter seasons (November 2007-May 2009) at the Reinier de Graaf Hospital, Delft, which was joined 
in the second season by the Groene Hart Ziekenhuis, Gouda, the Netherlands. Both serve as university teaching hospitals.

For this prospective cohort study of pediatric pertussis infections, specimens for pathogen diagnosis (mostly nasal wash specimens/nasopharyngeal aspirates (NWSs) or sometimes throat swabs) were collected from all children $<12$ years of age with suspected ARIs who were referred to the pediatrician. All patients, or their legal representatives, gave informed consent. Clinical management was based on pediatric history and physical examination. The pediatrician decided whether to perform pertussis diagnostics on the basis of the WHO definition of pertussis. However, due to some subjective criteria in this definition, the interpretation of the criteria might be different between doctors. Therefore, strict indications for performing pertussis diagnostics were not defined in this study. The method used for detection of $B$. pertussis in these specimens was an RT-PCR targeting IS481.

In the first winter season laboratory confirmation of $B$. pertussis infection was only performed in case of clinical suspicion of pertussis. In the second season laboratory testing was performed in all cases with or without clinical suspicion. In cases without clinical suspicion diagnostics was performed retrospectively on NSWs that were still available. Unfortunately, it was not possible to perform retrospective analysis on the samples of unsuspicious cases in the first winter season because those samples were not preserved (see Figure 1). Four groups were formed: 1.Clinical suspicion RT-PCR pertussis positive (Figure 1, group $A$ and $C$ ); 2. Clinical suspicion RT- PCR pertussis negative (Figure 1, group B and D); 3. Non suspicion RT-PCR pertussis positive (Figure 1, group E) and 4. Non suspicion RT-PCR pertussis negative (Figure 1, group F).

Details about in- and exclusion criteria, definitions of upper (URTI) en lower respiratory tract infections (LRTI), data collection and sample processing have been published before. ${ }^{12}$ Clinical data were prospectively collected for each patient by using a case report form by the clinician and missing data and laboratory parameters were retrieved from the electronical medical and hospital records. Variables used for analysis include: age, gender, fever, paroxysmal cough, rhinorrhea, wheezing, apneas, nasogastric feeding, days of illness, disease severity score, hospitalization and days in hospital, antibiotic therapy, location of infection (URTI, LRTI), diagnostic methods and presence of co-infections.

The disease severity score used in this study is a modification of the severity score developed by Gern. ${ }^{13}$ In our modified score, fever, cough, rhinorrhea and duration of illness $>4$ days count 1 point each. Apnea counts 3 points. Wheezing, cyanosis, retractions and tachypnea count 5 points each. The maximum score is 27 .

\section{Statistical analysis}

Demographic characteristics were extracted and frequencies were calculated using SPSS 18 (SPSS, Chicago, IL). The following three intimately linked analyses have been performed with the aim to find discriminative parameters for pertussis. 


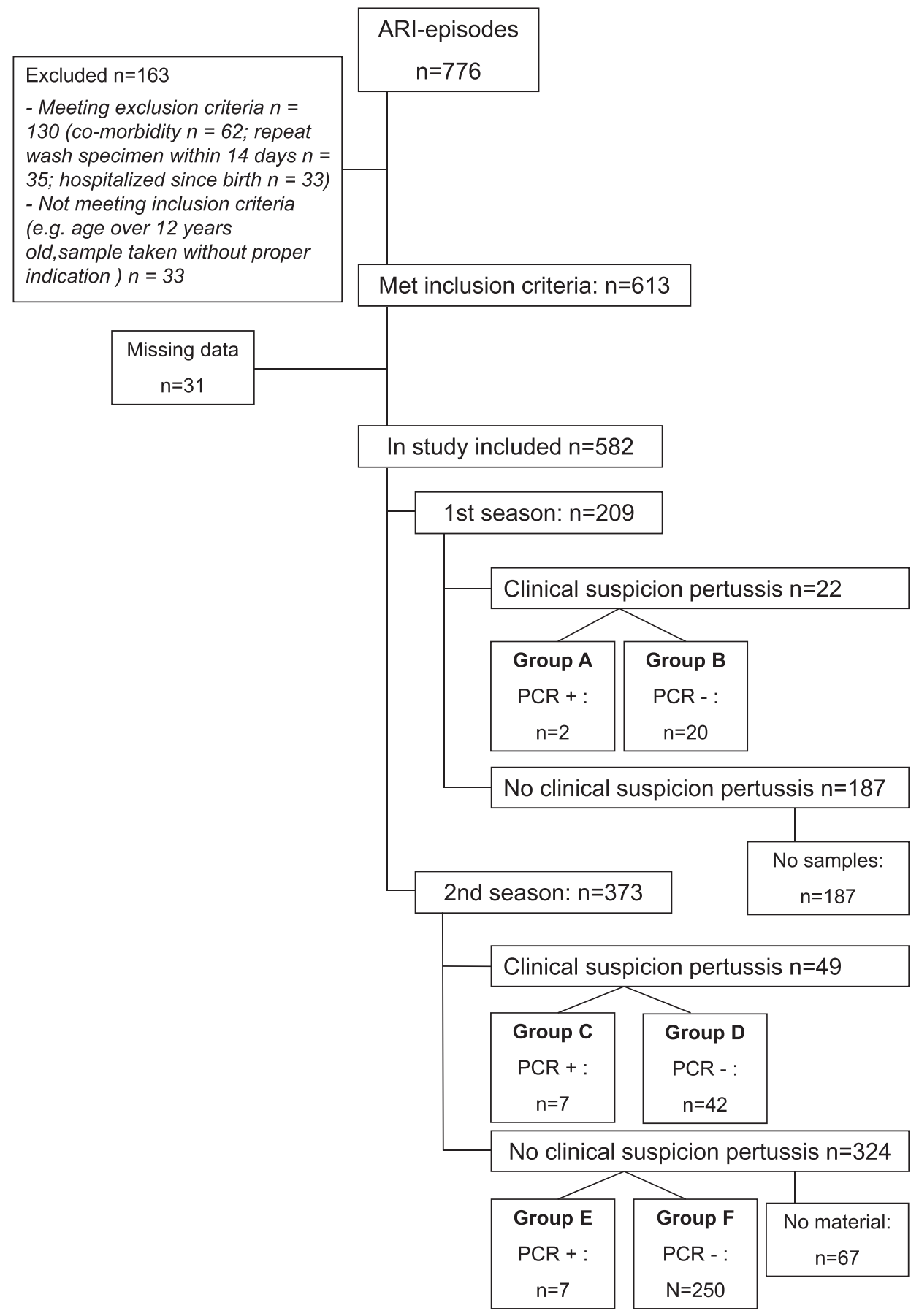

Figure 1. Flowchart of patient enrollment. 
In the first analysis we attempted to uncover discriminative parameters for clinical suspicion of pertussis by comparing clinical suspicious RT-PCR-positive cases (group $A$ and $C, n=9$ ) versus clinical suspicious PCR-negative cases (group $B$ and $D$, $n=62$ ) (analysis took place on both winter seasons). In the second analysis (restricted to the second season) we tested which clinical parameters distinguished clinical suspected pertussis cases (group $C, n=7$ ) from non-suspected pertussis cases (group $E, n=7)$ cases. In the third analysis (restricted to the second season): all RT- PCRpositive samples (group $C$ and $E, n=14$ ) were compared to all RT-PCR negative samples (group $D$ and $F, n=292$ ) to further analyze predictive clinical parameters.

To test differences in (multiple) clinical parameters of two groups multivariate analysis were performed using a non-parametric test called Permanova (for details see Appendix)..$^{14}$ If the multivariate analysis showed significant differences between the groups tested, post-hoc univariate analyses were performed using a Kruskall Wallis and binomial tests (details see Appendix) to see which parameters contributed to this difference. The false discovery ratio was used to control for the family wise error rate. ${ }^{15}$ To visualize the (multidimensional) differences between the groups, a non-metric dimensional scaling (NMDS) was applied, which displays the patients according to their similarity to each other ${ }^{16}$ (for details see Appendix). Analysis were performed using the statistical software ' $R$ ' (R Development Core Team ${ }^{17}$ ). Significance was determined at a level of $\alpha<0.05$.

\section{Medical ethical approvement}

The Evaluation of Viral Diagnostics on Respiratory Infections in Children trial protocol was approved by the regional medical ethics committee and The Central Committee on Research Involving Human Subjects (known by its Dutch initials, CCMO, Centrale Commissie Mensgebonden Onderzoek) number NL13839.098.06.

\section{RESULTS}

\section{Patient enrollment}

In total, 776 NWSs were analyzed. We excluded 163 because they were obtained from children who did not meet inclusion criteria for various reasons (see Figure 1). Of the 613 samples who did met the inclusion criteria, we excluded another 31 samples because the clinical data were incomplete. Of the remaining 582 NWSs (from 542 patients), 209 were included in the first season and 373 cases in the second season. Both seasons included in our study were seasons with high incidence of pertussis in the Netherlands (40-50 cases per 100.000). ${ }^{18}$

Seventy-one samples were taken from children with clinical suspicion for pertussis ( $1^{\text {st }}$ season $n=22 / 2^{\text {nd }}$ season $n=49$ ). $P C R$ analysis on pertussis was performed on these samples prospectively. In the second season 324 samples from non-suspicious children were retrospectively analyzed. Unfortunately, of 67 samples 
(out of 324 NWSs) too little material was left for RT-PCR after thawing, leaving 257 samples for retrospective analysis. A summary of in- and exclusion numbers is given in Figure 1. Mean age was 8,2 months (median 4.2) and $57,7 \%$ was male. URTI was diagnosed in $324 / 582(55,7 \%)$ children. Exclusively LRTI in $2 / 582(0,3 \%)$ and combined infections in $232 / 582(39,9 \%)$ children. Paroxysmal cough was found in $97 / 582(16,7 \%)$ children and $434 / 582(74,6 \%)$ were admitted to the pediatric ward.

\section{Outcomes}

Table 1 shows the number of pertussis cases diagnosed in each of the two seasons. In the first winter season clinical suspicion of pertussis was raised in 22 cases (group $A$ and B) out of $209(10,5 \%)$, two cases of pertussis were diagnosed by RT-PCR $(2 / 22=9,1 \%)$. In the second winter season clinical suspicion of pertussis was raised in 49 cases (group C and D) out of $373(13,1 \%)$, seven cases of pertussis were diagnosed by RT-PCR (7/49 = 14,3\%) (group C). In the second season another seven cases were found in the non-suspicion group ( $7 / 257=2,7 \%$ ) (group E). All NWSs were also tested for $B$. parapertussis, but no cases were found in our study.

The clinical features of the four identified groups in the second winter are shown in Table 2. Fourteen cases tested positive for pertussis (group C, (clinical suspicion RT-PCR positive), and group E (non-suspicion RT-PCR positive)). All fourteen pertussis patients showed signs of an URTI, but that symptom was one of the study inclusion criteria. Ten out of these 14 were also diagnosed with LRTI. All four patients with exclusively URTI fell into the clinical non-suspicion group. Only one patient in the non-suspicion group suffered from paroxysmal cough. Viral co-infections were found in 11 out of 14 cases: in the suspected pertussis group 6 out of 7 had viral co-infection ( 1 virus detected $n=6$ ) in the unsuspected pertussis group 5 cases had viral co-infection ( 1 virus detected $n=3 ; 2$ viruses detected $n=2$ ). Influenza $A$,

Table 1. Number of pertussis cases per season

\begin{tabular}{|c|c|c|}
\hline & $\begin{array}{l}\text { First winter } \\
\text { Season 2008-2009 } \\
(n=209)\end{array}$ & $\begin{array}{l}\text { Second winter } \\
\text { Season 2009-2010 } \\
(\mathrm{n}=373)\end{array}$ \\
\hline \multicolumn{3}{|l|}{ Clinical suspicion of pertussis } \\
\hline Clinical suspicion of pertussis (\%) & $22 / 209(10,5)$ & 49/373 $(13,1)$ \\
\hline Prospective $\mathrm{PCR}$ B. pertussis positive $\mathrm{n} / \mathrm{N}(\%)$ & $2 / 22(9,1)$ & $7 / 49(14,3)$ \\
\hline \multicolumn{3}{|l|}{ No clinical suspicion of pertussis } \\
\hline No clinical suspicion of pertussis (\%) & $187 / 209(89,5)$ & $324 / 373(86,9)$ \\
\hline Material for retrospective $P C R$ & $0 / 187(0,0)$ & $257 / 324(79,3)$ \\
\hline Retrospective PCR B. pertussis positive, n/N (\%) & $N A$ & $7 / 257(2,7)$ \\
\hline Total number of Pertussis cases, n/N (\%) & $2 / 209(1,0)$ & $14 / 373(3,8)$ \\
\hline
\end{tabular}

NA: not applicable. 
Table 2. Features of cases in the second season, divided in four groups

\begin{tabular}{|c|c|c|c|c|}
\hline & $\begin{array}{l}\text { Clinical suspicion } \\
\text { RT-PCR positive } \\
\mathrm{N}=7 \\
\text { (Figure 1, } \\
\text { group C) }\end{array}$ & $\begin{array}{l}\text { Clinical suspicion } \\
\text { RT-PCR negative } \\
\mathrm{N}=42 \\
\text { (Figure 1, } \\
\text { group D) }\end{array}$ & $\begin{array}{l}\text { Non-suspicion } \\
\text { RT-PCR positive } \\
\mathrm{N}=7 \\
\text { (Figure 1, } \\
\text { group E) }\end{array}$ & $\begin{array}{l}\text { Non-suspicion } \\
\text { RT-PCR negative } \\
\mathrm{N}=250 \\
\text { (Figure 1, } \\
\text { group F) }\end{array}$ \\
\hline Male, n & 4 & 30 & 1 & 147 \\
\hline Age, months, mean (range) & $14,8(1,2-49,6)$ & $4,8(0,1-21,7)$ & $3,8(0,6-8,7)$ & $7,6(0,1-89,4)$ \\
\hline \multicolumn{5}{|l|}{ Clinical features } \\
\hline In-hospital cases, n & $6(85,7 \%)$ & $30(71,4 \%)$ & $5(71,4 \%)$ & $182(72,8 \%)$ \\
\hline Fever, $\mathrm{n}$ & $3(42,9 \%)$ & $18(42,9 \%)$ & $1(14,2 \%)$ & $131(52,4 \%)$ \\
\hline Coughing, n & $7(100 \%)$ & $41(97,6 \%)$ & $7(100 \%)$ & $207(82,8 \%)$ \\
\hline Rhinorrhea, n & $7(100 \%)$ & $39(92,9 \%)$ & $7(100 \%)$ & $231(92,4 \%)$ \\
\hline Paroxysmal cough, n & $6(85,7 \%)$ & $25(59,5)$ & $1(14,2 \%)$ & $27(10,8 \%)$ \\
\hline $\mathrm{CRP}>40 \mathrm{mg} / \mathrm{L}, \mathrm{n}$ & $0(0 \%)$ & $3(7,1 \%)$ & $1(14,2 \%)$ & $26(10,4 \%)$ \\
\hline $\begin{array}{l}\text { Oxygen therapy } \\
\text { necessary, } \mathrm{n}\end{array}$ & $2(28,6 \%)$ & $15(35,7 \%)$ & $2(28,6 \%)$ & $105(42,0 \%)$ \\
\hline Nasogastric feeding, $n$ & $1(14,3 \%)$ & $5(11,9 \%)$ & $0(0,0 \%)$ & $27(10,8 \%)$ \\
\hline Wheezing, $\mathrm{n}$ & $3(42,9 \%)$ & $15(35,7 \%)$ & $1(14,2 \%)$ & $113(45,2 \%)$ \\
\hline Apnoe, $\mathrm{n}$ & $0(0 \%)$ & $3(7,1 \%)$ & $0(0,0 \%)$ & $10(4,0 \%)$ \\
\hline $\begin{array}{l}\text { Days of illness, mean } \\
\text { (range) }\end{array}$ & $18,3(5-37)$ & $9,7(2-42)$ & $10,4(5-18)$ & $8,3(1-35)$ \\
\hline $\begin{array}{l}\text { Disease severity score, } \\
\text { mean (range) }\end{array}$ & $9,9(0-19)$ & $11,7(0-24)$ & $9,6(3-18)$ & $13,4(0-27)$ \\
\hline \multicolumn{5}{|l|}{ Disease severity score } \\
\hline$<6$ & 2 & 9 & 2 & 65 \\
\hline $7-13$ & 3 & 16 & 3 & 55 \\
\hline $14-19$ & 2 & 14 & 2 & 75 \\
\hline$>20$ & 0 & 3 & 0 & 55 \\
\hline \multicolumn{5}{|l|}{ Clinical diagnosis } \\
\hline Exclusively URTI & 0 & 23 & 4 & 133 \\
\hline Exclusively LRTI & 0 & 0 & 0 & 1 \\
\hline Combined URTI/LRTI & 7 & 18 & 3 & 106 \\
\hline No URTI or LRTI & 0 & 1 & 0 & 10 \\
\hline \multicolumn{5}{|l|}{ Pertussis diagnosis } \\
\hline $\begin{array}{l}\text { PCR throat swab } \\
\text { material, } \mathrm{n}\end{array}$ & 4 & $x$ & 0 & $x$ \\
\hline PCR NWS, n & 3 & $x$ & 7 & $x$ \\
\hline Serology, positive, $\mathrm{n}$ & 1 & $x$ & 0 & $x$ \\
\hline Culture, positive $\mathrm{n}$ & 0 & $x$ & 0 & $x$ \\
\hline \multicolumn{5}{|l|}{ Viral (co)infection } \\
\hline None & 1 & 7 & 2 & 37 \\
\hline 1 virus & 6 & 21 & 3 & 146 \\
\hline$\geq 2$ virusses & 0 & 14 & 2 & 67 \\
\hline \multicolumn{5}{|l|}{ Antibiotic therapy } \\
\hline None & 0 & 26 & 4 & 158 \\
\hline Amoxicillin, $\mathrm{n}$ & 1 & 9 & 2 & 94 \\
\hline Claritromycine, $n$ & 7 & 7 & 1 & 8 \\
\hline
\end{tabular}


RSV B, Rhino- and Bocavirus were the most common pathogens found. All children in the clinical suspicion group were prescribed claritromycin, in case of suspected pneumonia amoxicillin was prescribed as well. Of the pertussis cases, 6/14 were appropriately immunized, 4 were too young to have received completed immunization and 4 were not immunized based on their parental beliefs. Of the 14 cases 11 were admitted to the pediatric ward: $6 / 7$ (86\%) in the suspected pertussis group and 5/7 $(71 \%)$ in the unsuspected pertussis group.

Multivariate analyses were performed on the groups described in analysis 1, 2 and 3. No significant differences were found between the clinical suspicion RT-PCR positive group (group $A$ and $C$ ) and the clinical suspicion RT-PCR negative group (group B and D) (Analysis 1: $p$ - value 0,12 ).

Among those who tested positive for pertussis in the second season (group $C$ and $E$ ), multivariate analysis showed significant differences between the suspected (group C) and the unsuspected pertussis group (group E) (Analysis $2 p=0,03$ ). Figure 2 is a visualization of the differences (in characteristics) between both groups and shows that the two groups can be separated from one another in space, which means that the two groups differ in clinical parameters.

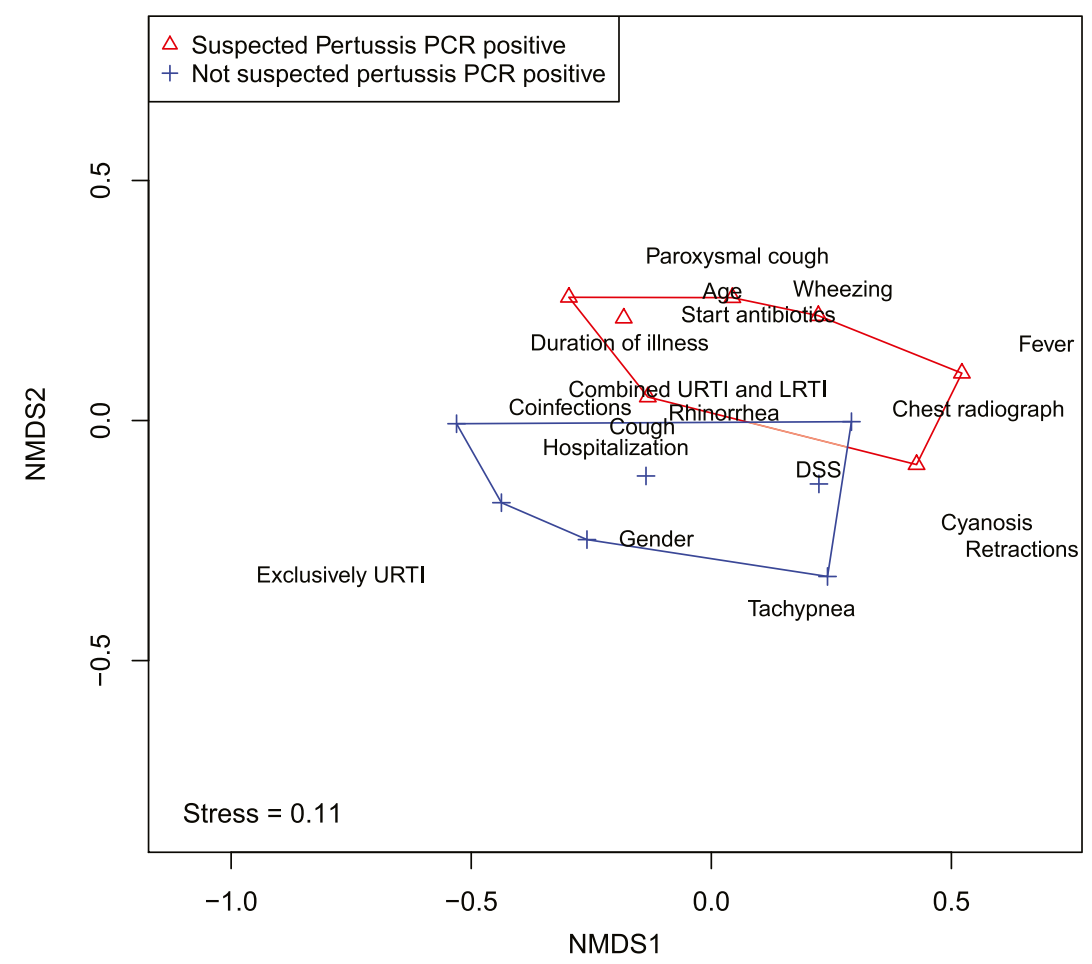

Figure 2. Visualization of the differences (in characteristics) between the suspected and unsuspected pertussis group. 
To test which factors contributed to the difference between both groups, a posthoc test was performed, in which each factor was analyzed separately (results shown in Table 3). In the unsuspected pertussis group (group E) less children had paroxysmal cough $(p<0,01)$ and less antibiotics were prescribed $(p=0,01)$. Location of infection also significantly differed between the two groups: more URTIs were found in the unsuspected pertussis group $(p=0,01)$ and more combined URTI and LRTI were found in de clinical suspected group $(p=0,01)$ (group C). Other clinical findings (feeding support, presence of fever) did not differ between the two groups. Considering that ARI was the main characteristic for inclusion, general symptoms belonging to ARI (cough, rhinorrhoea) were present in all participants and could therefore not be included in this post-hoc test. Apnea was not observed in one of the groups, therefore this parameter was not included in the post hoc test as well.

No significant differences were found between all RT- PCR positive cases (group $C$ and E) and all RT-PCR negative cases (group D and F) (Analysis 3: p-value 0,48).

Since paroxysmal cough is considered one of the main symptoms of pertussis, we retrospectively assessed the frequency of paroxysmal cough in ARI. Paroxysmal cough

Table 3. Post-hoc univariate analysis (analysis 2): PCR Pertussis positive: suspected (group III) versus non-suspected pertussis group (group $\mathrm{V}$ )

\begin{tabular}{|c|c|}
\hline Variable & $P$ value \\
\hline Age (months) & $0,180^{\mathrm{a}}$ \\
\hline Gender & $0,112^{b}$ \\
\hline Coinfections & $0,708^{a}$ \\
\hline Hospitalization & $0,513^{b}$ \\
\hline Duration of Illness & $0,140^{\mathrm{a}}$ \\
\hline Fever & $0,264^{b}$ \\
\hline Cough & $\mathrm{Np}$ \\
\hline Rhinorrhea & $\mathrm{Np}$ \\
\hline Apnea & $\mathrm{Np}$ \\
\hline Wheezing & $0,271^{b}$ \\
\hline Cyanosis & $0,791^{b}$ \\
\hline Retractions & $0,515^{b}$ \\
\hline Tachypnea & $0,507^{b}$ \\
\hline Paroxysmal coughing & $0,0076^{b}$ \\
\hline Disease severity score & $0,844^{a}$ \\
\hline Combined URTI and LRTI & $0,0132^{b}$ \\
\hline Exclusively URTI & $0,0136^{b}$ \\
\hline Chest radiograph & $0,509^{b}$ \\
\hline Start antibiotics & $0,0122^{b}$ \\
\hline
\end{tabular}

a Kruskal Wallis test for continuous variables.

${ }^{b}$ Binomial test for discrete variables.

$\mathrm{np}=$ not possible.

Significant differences noted as bold. 
was reported by the parents or observed by the clinician. Paroxysmal cough was often seen in children with ARIs (97/582 = 16,7\%). In 43 of 97 cases with paroxysmal cough the consulting pediatrician had clinical suspicion of pertussis and decided to perform diagnostics, 8 out of these 97 were proven pertussis. In 54 of 97 cases with paroxysmal cough the consulting pediatrician had no clinical suspicion of pertussis. Frequently alternative diagnoses were noted in the medical chart, mostly bronchiolitis. Two-thirds of these cases were RSV positive, some were positive for other viruses. Retrospectively, only one positive pertussis case was found in this group.

\section{DISCUSSION}

In literature, paroxysmal cough is considered the most important classical symptom of pertussis; it is also a major criterion in clinical case definitions of de World Health Organization and Centers for Disease Control and Prevention. Also in the clinical case definitions proposed by the Global Pertussis Initiative Roundtable Meeting in 2011, paroxysmal cough is still considered a major criteria in children above 3 months of age. ${ }^{11}$ However this study shows that clinical suspicion based on paroxysmal coughing only predicts accurately in about $10-15 \%$ of cases. Based on the second study season, theoretically 4 out of 5 pertussis cases were accurately recognized $(100-((2,7 / 14,3) \times 100)=81,1 \%)$ and 1 out of 5 pertussis cases was missed $((2,7 / 14,3) \times 100=18,9 \%)$ if pertussis diagnostics are only performed when the doctor has clinical suspicion of pertussis. In accordance with other reports, $4,8,9$ we observed that paroxysmal cough is not specific for pertussis. In the unsuspected pertussis group less children suffered from paroxysmal cough and more children had only symptoms of an URTI. This suggests that the current clinical case definitions of pertussis are not sufficient for diagnosing all pertussis cases. Especially the atypical and mild infections, more frequently seen in unvaccinated children, are missed. Moreover, these children are also at risk for developing severe life threatening apneas if treatment is delayed. We showed that paroxysmal cough is also seen in children with common viral respiratory infections, which implies that further research should focus on determining accurate clinical predictors of pertussis.

Our study suggests that reported incidences of pertussis underestimate the true incidences. Our study results are supported by seroprevalence studies that have shown that only $20-25 \%$ patients with positive serology recall symptoms during the preceding year. ${ }^{1,20}$

Different studies showed that in respiratory infections often more than one pathogen is found. It is not clear which pathogen is the primary causative agent and which associations between pathogens contribute to disease severity. ${ }^{21}$ Also in pertussis, co-infections with respiratory pathogens often occur. ${ }^{9,22}$ In our study 11/14 $(78,6 \%)$ patients with pertussis had viral co-infections. Co-infections did not seem to explain the differences found between the unsuspected and suspected pertussis group. 
We could not determine if these infections occurred simultaneously or consecutively. Clinical features of cases with mixed infections do not differ from those with only one organism present. 4,8,22 In cases of mixed infections, it is unclear which pathogen contributes most to the disease symptoms. It is possible that only one organism causes symptoms while the other micro-organism is only residing in the respiratory tract. Although some studies ${ }^{23}$ suggest asymptomatic carriage of $B$. pertussis, situations in which $B$. pertussis is detected more likely reflect asymptomatic or mild infections. The much higher seroprevalence compared to the number of reported cases supports the idea of asymptomatic infections or carriage. ${ }^{1}$ Additionally, in the situation of co-infection, coughing due to viral infection might contribute to transmission of pertussis as well.

The clinical severity of pertussis infections may be modified by vaccination. Fully vaccinated children are thought to have more silent or mild pertussis infections and more severe presentations are seen in unvaccinated children, especially at a young age. ${ }^{2,5}$ In the Netherlands children are vaccinated against pertussis with an acellular vaccine at the age of 2, 3, 4 and 11 months and 4 years. ${ }^{18}$ In the study period (2007-2009), overall vaccination coverage for pertussis in the Netherlands was around $95 \%$ for infants, and $91 \%$ for toddlers. In both participating hospitals vaccine coverage was equal to the national percentage. ${ }^{18}$ In our study 8 out of 14 children with pertussis were not immunized (yet), from which 4 cases were found based on clinical suspicion. Of these 8 children, five were less than two months of age and therefore not (yet) immunized. The other three children were not immunized for religious reasons. The other six children with pertussis were immunized with the acellular vaccine, one child was 4 years and fully immunized. The age of the other five varied between 3 and 9 months (mean 6.3 months). Vaccination strategy and type of vaccination are matter of interest in literature, duration of immunity might differ between de whole cell and the acellular vaccines. ${ }^{24}$ In our study, almost all children were vaccinated with the acellular vaccine, since all children in The Netherlands born after January 2005 have been vaccinated with this type of vaccine. De Greeff et al. demonstrated that household contacts play and important role in transmission of pertussis to children and show that 1-3 years after vaccination children are again susceptible for pertussis. ${ }^{6}$ It has also been shown that infection may occur shortly after vaccination, not always with typical clinical symptoms ${ }^{3,25}$ and depending on the efficacy of the vaccine used.

In this study we used RT-PCR to detect $B$. pertussis, mostly on NWS/nasopharyngeal aspirates and only a few times on throat swabs. The method of specimen collection depended on the experience in the local hospital. NWS/ nasopharyngeal aspirates and throat swabs provide mucus that contains columnar respiratory epithelial cells, the target cell for attachment of B. pertussis. ${ }^{2}$ In 2005, the Pertussis Consensus Group recommended NWSs/nasopharyngeal aspirates as the optimal sample for RT-PCR in infants and throat swabs as an possible alternative in older children. ${ }^{26}$ In some studies 
throat swabs are considered suboptimal to nasopharyngeal swabs, but Holberg et al. showed that they have similar sensitivity. ${ }^{27}$ In our study, PCR on throat swabs was done in a minority of cases (11 of which four tested positive for pertussis). RT-PCR is a rapid, sensitive and specific diagnostic test, may detect infection early and later in disease progression and may be used in vaccinated children, in whom serology is unreliable. ${ }^{2,7}$ It is suggested that RT-PCR for pertussis remains positive at least three weeks from onset of catarrhal symptoms. ${ }^{2}$ After this period, the usefulness of RT-PCR declines and serology becomes more important in unimmunized children ${ }^{7}$.

The PCR target used for diagnosis in this study was IS481, Consequently, we cannot distinguish between B. pertussis, B. holmesii and B. bronchiseptica. B. holmesii has been found in three Dutch patients with pertussis-like symptoms ${ }^{28}$ but the prevalence appears to be low. ${ }^{29}$ Furthermore, $B$. holmesii has mainly been found in adolescents and adults. ${ }^{30}$ Therefore, we consider it is unlikely that our data are an overestimation of true data. The use of the IS481 target instead of species-specific targets in a clinical setting is further supported by data from a recent study of Spicer et al. He reported that 222 out of 520 (42.7\%) IS481 positive nasopharyngeal specimens were unable to be confirmed as having $B$. pertussis or $B$. holmesii by species specific PCR assays. This likely reflects the greater sensitivity of the IS481 target, because there are more targets per organism than in an assay using species specific targets. ${ }^{31}$

There are limitations to this study. First, the number of RT-PCR-positive pertussis samples is small, limiting the application of the results to the general population. Second, serology was not performed. Had serology been included, more pertussis cases might have been found. Another limitation was that no retrospective data on the first season were available. Also, we cannot exclude some selection bias in our study, since most children were referred to the hospital only after initial assessment by a primary physician, as is common in the Dutch healthcare system. Therefore, patients with milder disease might be underrepresented. Furthermore it might be important to evaluate what makes a physician think whether a patient has pertussis, considering the fact that our study and other studies show that paroxysmal cough is not a specific predictor of pertussis. ${ }^{4,8,19}$ Also, the possible differing interpretations of the definition of paroxysmal cough between physicians could have led to interpretation bias, with both the risk of over- and underestimation of clinical suspect pertussis cases.

We believe that the results of our study adequately reflect the situation in national hospitals and most likely also internationally: in children with respiratory infections, pertussis diagnostics are not routinely performed, but only in case of clinical suspicion. The current clinical criteria for pertussis are all based on paroxysmal cough, which, as we showed, is not a good predictor in atypical pertussis infections. The study population of previously healthy children with ARI are comparable to other pediatric populations. Therefore we believe our results are also generalizable to similar settings. 


\section{CONCLUSIONS}

Children with pertussis may present with classic or atypical symptoms. Presentation may mimic a viral respiratory tract infection, with the consequence of continuous spreading of pertussis in the population. Our study showed that when the initiation of pertussis diagnostics is based on clinical suspicion, about 1 in 5 cases (19\%) is missed. Despite being widely accepted as a clinical criteria on pertussis, paroxysmal cough is not a good predictor of a pertussis infection in our study. In our opinion pertussis cannot be diagnosed solely on clinical grounds. Therefore, since pertussis is a treatable disease, we stress the importance of $B$. pertussis diagnostics, especially in children with respiratory symptoms. We advocate that if one searches for a causative pathogen, one should search for treatable pathogens like B. pertussis. Although more frequent laboratory diagnostics may help to limit spread of pertussis in the population, it comes with high costs. Studies investigating the cost-effectiveness are warranted.

\section{APPENDIX}

\section{Permanova}

PERMANOVA is the non-parametric analogue of the MANOVA. ${ }^{14} \mathrm{~A}$ permanova can take both continuous as discrete variables to calculate significant differences between multiple groups. It does so by testing whether the similarity of the individuals, based on their characteristics, within a group is smaller than the similarity of individuals from different groups. In this study Gower distance was taken a distance measure, since this measure can handle a mix of datatypes (binary, discrete and continuous). To test whether the distances within a group are smaller than between groups a permutation test was performed, by randomly assigning group labels 1 ) Clinical suspicion PCR positive $(n=9)$ vs Clinical suspicion PCR negative $(n=62) ; 2)$ Clinical suspicion PCR positive ( $n=7)$ and no clinical suspicion PCR positive $(n=7)$; and 3 ) all PCR positive (14 patients) vs. all PCR negative (292) to each patient. This randomization was repeated a large number times (999) and gives a null distribution of distance values (hypothesis: no differences between groups). Subsequently, the F test was used to determine if the observed outcome significantly differed from the null expectation. The larger the value of $F$, the more likely it is that the null hypothesis is wrong, and that the observed outcome is not likely to have occurred by chance. ${ }^{14}$ Like a MANOVA, a permanova is sensitive to differences in variance among groups, particularly when sample sizes differ substantially. Since we cannot apply a permanova on the full group sizes, analysis 1 and 3 were performed slightly differently. For analysis 1 , we randomly took 9 patients from the group of 62 and compared those with the suspected PCR positive. We then tested for homogeneity of variances (using the method described by Anderson ${ }^{32}$ ) and run the permanova as described above for group 2. This procedure was repeated 1000 times. The two groups can be considered significantly different from each other when more than 950 permanova's (out of 1000) show a significant 
difference between the groups. ${ }^{33}$ This procedure was also used for comparing the two groups in analysis 3. Both analysis 1 and 3 showed no significant differences between the groups. Thus there are no significant differences between the clinical suspicion $P C R$ positive and clinical suspicion PCR negative group. Also no differences were found between all PCR positive versus all PCR negative cases.

\section{Binomial test}

Given the significant differences between the clinical suspected and unsuspected group, we subsequently tested which variables contributed to the differences among the groups (post-hoc test). For the binary variables, we used a binomial test. We tested the probability that the frequency of the symptoms being present in the different groups could be due to chance. To do so we compared the ratio of frequencies of a particular symptom in two groups to the ratio of frequencies of the two groups assuming no differences between the two groups (null hypothesis: each patient, regardless which group it is in, has an equal probability to show a particular symptom). The frequency under the null model was generated by drawing 7 and 7 times from a binomial distribution with probability of 0.5 . This was repeated 10,000 times. The thus derived frequency distribution was compared to the observed frequency. If the observed frequency falls outside the $95 \%$ confidence interval of the null distribution, we consider it unlikely that the observed frequency distribution is due to chance.

\section{Non metric dimensional scaling (NMDS)}

The difference between the patients of the suspected pertussis and unsuspected pertussis group was tested using a PERMANOVA. The test for significant differences in the PERMANOVA is based on the dissimilarity matrix and tests whether patients in a group are more similar to each other (within a group) than between groups. Recall that the dissimilarity matrix is calculated based on the characteristics of the patients and summarizes how similar patients are, based on their characteristics, in one number. Nonmetric multidimensional scaling (NMDS) is a way to visualize these dissimilarities in a chosen number of dimensions (in this paper two). The position in two dimensions of the individual patients is shown such that the rank order of the distance between the patients in the plot agrees with the dissimilarities of the patients in dissimilarity matrix. The degree to which the rank order distances agree with the dissimilarities is called "stress". The lower the stress the better. The NDMS procedure seeks the ordination with lowest stress.

\section{ACKNOWLEDGEMENTS}

We thank Perry van Wunnink and Leo C. Smeets for performing all laboratory assays. We thank Marjon van Meriënboer and Ria van Leeuwen for arranging data management and logistics. 


\section{REFERENCES}

1. de Greeff SC, de Melker HE, van Gageldonk PGM, Schellekens JFP, van der Klis FRM, Mollema L, Mooi FR, Berbers GAM: Seroprevalence of pertussis in The Netherlands: evidence for increased circulation of Bordetella pertussis. PLoS One 2010, 5(12):e14183.

2. Leber AL: Pertussis: relevant species and diagnostic update. Clin Lab Med 2014, 34(2): 237-255.

3. de Melker HE, Versteegh FGA, Schellekens JFP, Teunis PFM, Kretzschmar M: The incidence of Bordetella pertussis infections estimated in the population from a combination of serological surveys. J Infect 2006, 53(2):106-113.

4. Cosnes-Lambe C, Raymond J, Chalumeau M, Pons-Catalano C, Moulin F, de Suremain N, Reglier-Poupet H, Lebon P, Poyart C, Gendrel D: Pertussis and respiratory syncytial virus infections. Eur J Pediatr 2008, 167(9):1017-1019.

5. Barlow RS, Reynolds LE, Cieslak PR, Sullivan AD: Vaccinated children and adolescents with pertussis infections experience reduced illness severity and duration, Oregon, 2010-2012. Clin Infect Dis 2014, 58(11):1523-1529.

6. de Greeff SC, Mooi FR, Westerhof A, Verbakel JMM, Peeters MF, Heuvelman CJ, Notermans DW, Elvers LH, Schellekens JFP, de Melker HE: Pertussis disease burden in the household: how to protect young infants. Clin Infect Dis 2010, 50(10):1339-1345.

7. Zouari A, Smaoui H, Kechrid A: The diagnosis of pertussis: which method to choose? Crit Rev Microbiol 2012, 38(111):111-121.

8. Nuolivirta K, Koponen P, He Q, Halkosalo A, Korppi M, Vesikari T, Helminen M: Bordetella pertussis infection is common in nonvaccinated infants admitted for bronchiolitis. Pediatr Infect Dis J 2010, 29(11):1013-1015.

9. Abu Raya B, Bamberger E, Kassis I, Kugelman A, Srugo I, Miron D: Bordetella pertussis infection attenuates clinical course of acute bronchiolitis. Pediatr Infect Dis J 2013, 32(6):619-621.

10. Tozzi AE, Pandolfi E, Celentano LP, Massari M, Salmaso S, Ciofi degli Atti ML, Group E-NS: Comparison of pertussis surveillance systems in Europe. Vaccine 2007, 25(2):291-297.

11. Cherry JD, Tan T, Wirsing von Konig CH, Forsyth KD, Thisyakorn U, Greenberg D, Johnson D, Marchant C, Plotkin S: Clinical definitions of pertussis: Summary of a Global Pertussis Initiative roundtable meeting, February 2011. Clin Infect Dis 2012, 54(12):1756-1764.

12. Wishaupt JO, Russcher A, Smeets LC, Versteegh FGA, Hartwig NG: Clinical impact of RTPCR for pediatric acute respiratory infections: a controlled clinical trial. Pediatrics 2011, 128(5):1113-1120.

13. Gern JE, Martin MS, Anklam KA, Shen K, Roberg KA, Carlson-Dakes KT, Adler K, GilbertsonWhite S, Hamilton R, Shult PA, Kirk CJ, Da Silva DF, Sund SA, Kosorok MR, Lemansk RF: Relationships among specific viral pathogens, virus-induced interleukin-8, and respiratory symptoms in infancy. Pediatr Allergy Immunol 2002, 13(6):386-393.

14. Anderson MJ: A new method for non-parametric multivariate analysis of variance. Austral Ecol 2001, 26:32-46.

15. Benjamini $Y$, Hochberg Y: Controlling the false discovery rate: a practical and powerful approach to multiple testing. J R Stat Soc Ser B 1995, 57(1):289-300.

16. Borg I, Groenen PJF: Modern multidimensional scaling - theory and applications. 2nd edition. New York: Springer-Verlag; 2005.

17. R Development CoreTeam, 2011. R: A language and environment for statistical computing. In. Vienna, Austria.: R Foundation for Statistical Computing. 
18. Immunization coverage National Immunization Programme in the Netherlands, year of report 2006-2008. [http://www.rivm.nl/bibliotheek/rapporten/210021007.pdf/http:// www.rivm.nl/bibliotheek/ rapporten/ 210021010.pdf]

19. Arnold JC, Singh KK, Spector SA, Sawyer MH: Undiagnosed respiratory viruses in children. Pediatrics 2008, 121(3):e631-e637.

20. Versteegh FGA: Don't forget Bordetella. Am J Respir Crit Care Med 2012, 185(9):1027-1028.

21. van den Bergh MR, Biesbroek G, Rossen JW, de Steenhuijsen Piters WA, Bosch AA, van Gils EJ, Wang X, Boonacker CW, Veenhoven RH, Bruin JP, Bogaert D, Sanders EA: Associations between pathogens in the upper respiratory tract of young children: interplay between viruses and bacteria. PLoS One 2012, 7(10):e47711.

22. Versteegh FGA, Mooi-Kokenberg EANM, Schellekens JFP, Roord JJ: Bordetella pertussis and mixed infections. Minerva Pediatr 2006, 58(2):131-137.

23. Conover MS, Sloan GP, Love CF, Sukumar N, Deora R: The Bps polysaccharide of Bordetella pertussis promotes colonization and biofilm formation in the nose by functioning as an adhesin. Mol Microbiol 2010, 77(6):1439-1455.

24. Guiso N: How to fight pertussis? Ther Adv Vaccines 2013, 1(2):59-66. Page 10 of 10

25. Versteegh FGA, Schellekens JFP, Nagelkerke AF, Roord JJ: Laboratory- confirmed reinfections with Bordetella pertussis. Acta Paediatr 2002, 91(1):95-97.

26. Riffelmann M, Wirsing von Konig CH, Caro V, Guiso N: Nucleic Acid amplification tests for diagnosis of Bordetella infections. J Clin Microbiol 2005, 43(10):4925-4929.

27. Holberg-Petersen M, Jenum PA, Mannsaker T, Melby KK: Comparison of PCR with culture applied on nasopharyngeal and throat swab specimens for the detection of Bordetella pertussis. Scand J Infect Dis 2011, 43(3):221-224.

28. Mooi FR, Bruisten S, Linde I, Reubsaet F, Heuvelman K, van der Lee S, King AJ: Characterization of Bordetella holmesii isolates from patients with pertussis-like illness in The Netherlands. FEMS Immunol Med Microbiol 2012, 64(2):289-291.

29. Antila M, He Q, de Jong C, Aarts I, Verbakel H, Bruisten S, Keller S, Haanpera M, Makinen J, Eerola E, Viljanen MK, Mertsola J, Van der Zee A: Bordetella holmesii DNA is not detected in nasopharyngeal swabs from Finnish and Dutch patients with suspected pertussis. J Med Microbiol 2006, 55(Pt 8):1043-1051.

30. Njamkepo E, Bonacorsi S, Debruyne M, Gibaud SA, Guillot S, Guiso N: Significant finding of Bordetella holmesii DNA in nasopharyngeal samples from French patients with suspected pertussis. J Clin Microbiol 2011, 49(12):4347-4348.

31. Spicer KB, Salamon D, Cummins C, Leber A, Rodgers LE, Marcon MJ: Occurrence of 3 Bordetella species during an outbreak of cough illness in Ohio: epidemiology, clinical features, laboratory findings and antimicrobial susceptibility. Pediatr Infect Dis J 2014, 33(7):e162-e167.

32. Anderson MJ: Distance-based tests for homogeneity of multivariate dispersions. Biometrics 2006, 62(1):245-253.

33. Hilborn R, Mangel M: The ecological detective: confronting models with data. Princeton, New Jersey: Princeton University Press; 1997 


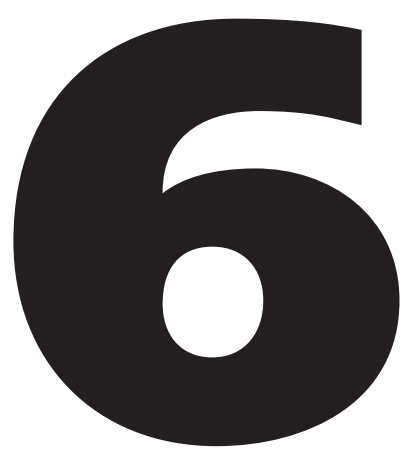




\section{PITFALLS IN INTERPRETATION OF CT-VALUES OF RT-PCR IN CHILDREN WITH ACUTE RESPIRATORY TRACT INFECTIONS}

Jérôme O. Wishaupt, Tjeerd van der Ploeg, Leo C. Smeets, Ronald de Groot, Florens G.A. Versteegh and Nico G. Hartwig

Journal of Clinical Virology 2017 May; 90:1-6 


\section{ABSTRACT \\ Background}

The relation between viral load and disease severity in childhood acute respiratory tract infections (ARI) is not fully understood.

\section{Objectives}

To assess the clinical relevance of the relation between viral load, determined by cycle threshold (CT) value of real-time reverse transcription polymerase chain reaction assays and disease severity in children with single- and multiple viral ARI.

\section{Study design}

582 children with ARI were prospectively followed and tested for 15 viruses. Correlations were calculated between CT values and clinical parameters.

\section{Results}

In single viral ARI, statistically significant correlations were found between viral loads of Respiratory Syncytial Virus (RSV) and hospitalization and between viral loads of Human Coronavirus ( $\mathrm{HCOV}$ ) and a disease severity score. In multiple-viral ARI, statistically significant correlations between viral load and clinical parameters were found. In RSV-Rhinovirus (RV) multiple infections, a low viral load of RV was correlated with a high length of hospital stay and a high duration of extra oxygen use. The mean CT value for RV, HCoV and Parainfluenza virus was significantly lower in single- versus multiple infections.

\section{Conclusion}

Although correlations between CT values and clinical parameters in patients with single and multiple viral infection were found, the clinical importance of these findings is limited because individual differences in host-, viral and laboratory factors complicate the interpretation of statistically significant findings. In multiple infections, viral load cannot be used to differentiate between disease causing virus and innocent bystanders.

\section{Keywords}

Child, Viral load, Cycle threshold value Respiratory infection Disease severity 


\section{BACKGROUND}

Acute respiratory infections (ARI) frequently occur in young children. Most infections have a viral cause and are usually mild. However, some patients need to be hospitalized because of a more severe course of disease. Factors determining disease severity are not fully understood.

Patient factors related to disease severity, like prematurity or congenital heart disease have been well known for many years. ${ }^{1}$ Other factors, such as the role of the immune system are studied recently. CD4 and CD8T cells, as well as NK cell numbers were found to be reduced in the peripheral blood of severe cases of RSV. ${ }^{2}$ Genetic factors also play an important role. Recently, a relation between gene expression profiles and disease severity in children with respiratory syncytial virus (RSV) infection was published, showing that expression of specific genes provides a promising biomarker of disease severity for RSV., ${ }^{3,4}$

Viral factors may also influence disease severity. Viruses such as RSV are known for their great burden of disease. ${ }^{5}$ Thus far, it is not known if the amount of virus in an individual patient is a determinant of disease severity. The amount of virus per milliliter body fluid is called viral load and this parameter is inversely correlated with cycle threshold (CT) value, defined as the number of cycles that are needed to yield a positive fluorescent amplification signal in a real-time reverse transcription-polymerase chain reaction test (RT-PCR). The lower the CT value, the higher the viral load.

The literature on the relation between disease severity and viral load is conflicting. Some investigators suggest a positive relationship, ${ }^{6-15}$ although others cannot confirm these results. ${ }^{16-20}$ Multiple viruses are detected rather frequently in children with respiratory infections and in these cases it is almost impossible to determine the causative pathogen and the relation between viral load and disease severity. ${ }^{21-23}$

\section{Objectives}

Since the relation between viral load and disease severity may be virus dependent, we studied this correlation for 15 different viruses. First, we studied infections in which only one virus was detected. With this information we subsequently studied cases in which multiple viruses were detected.

\section{Study design}

This study is part of the Evaluation of Viral Diagnostics on Respiratory Infections in Children-trial (EVIDENCE-trial), a multicenter controlled clinical trial, designed to evaluate the clinical impact of rapid result communication using RT-PCR as a diagnostic method in pediatric patients with ARI. The study protocol with inand exclusion criteria is described elsewhere. ${ }^{24}$ In summary, nasal wash specimen samples were obtained at first presentation at the emergency room or outpatient clinic from previously healthy children with ARI during two winter seasons between 2007 and 2009 in two Dutch hospitals. Clinical data were prospectively collected 
using standardized forms. Informed consent was obtained from all parents and the study protocol was approved by the national Medical Ethics Committee (CCMO \# ML13839.098.06)

\section{RT-PCR method}

Duplex RT-PCR assays were performed with all nasal wash specimen samples. The RT-PCR method and its validation procedure have been described previously. ${ }^{24}$ In summary, nucleic acid extraction was performed after addition of an internal control (RNA viruses: phocine distemper virus; DNA viruses: artificial plasmid) with an Xtractor gene nucleic acid extraction robot (Qiagen, Hilden, Germany) with an Invisorb virus RNA HTS 96 kit (Invitek, Berlin, Germany) and a Corbett DX DNA extraction kit (Qiagen). The input volume was $200 \mu \mathrm{l}$ and output was set to $100 \mu \mathrm{l}$. For RNA viruses, a random-primed reverse transcription reaction was performed with $57 \mu \mathrm{l}$ of RNA (MultiScribe RT [Applied Biosystems, Carlsbad, CA]). RT-PCR was performed with an in-house assay adapted from the Erasmus Medical Center (courtesy of Dr M. Schutten, Erasmus Medical Center, Rotterdam, The Netherlands) on an ABI 7500 thermocycler (Applied Biosystems). The PCR reaction was terminated at 45 cycles. Each reaction tube was internally controlled.

\section{Pathogens}

All samples were tested for RSV with a rapid bedside test and supplementary RT-PCR for 15 viruses. Viral subtypes were clustered into virus groups. The characteristics of these virus groups are summarized in Table 1.

\section{Diseaseseverityscore (DSS)}

The DSS used in this study is a modification of the severity score used by Gern et al $^{25,26}$ (Supplementary Table 1). A score of 0-7 represents mild disease, 8-18 moderate disease and 19-27 severe disease. The score system was used at initial presentation of children with respiratory symptoms at the emergency department or outpatient clinic.

\section{Statistics}

SPSS for Windows, version 21.0 (SPSS inc., IBM Company, Chicago, Illinois) was used for statistical analysis. Mann-Whitney $\mathrm{U}$ test was used to calculate the relation between $\mathrm{CT}$ value and hospitalization (Table 2) and to compare median CT values of viruses in single- and multiple infections (Table 3). Spearman correlation test was used to calculate correlations between $C T$ value and continuous variables with an abnormal distribution, like length of hospital stay (LOS), length of oxygen use and DSS, both in single and in multiple infections (Table 2). In multiple infections, analyses were made in group sizes with a minimum of 14 children. A p-value of $<0.05$ was considered as significant. The interpretation of the Spearman's correlation coefficient (rho) is independent of the statistical significance of the test. The rho indicates 
Table 1. Viral characteristics.

\begin{tabular}{|c|c|c|c|c|}
\hline Virus & $\begin{array}{l}\text { Genetic } \\
\text { material }\end{array}$ & $\begin{array}{l}\text { Incubation } \\
\text { perioda }^{\text {a }}\end{array}$ & Period of viral shedding ${ }^{a}$ & $\begin{array}{l}\text { Asymptomatic } \\
\text { infection }^{a}\end{array}$ \\
\hline RSV A, B & RNA & 2-8 days & $\begin{array}{l}\text { 3-8 days } \\
\text { young infants and } \\
\text { immunosuppressed people: } \\
\text { up to } 28 \text { days }\end{array}$ & $\begin{array}{l}\text { - young infants: not } \\
\text { common } \\
\text { - reinfections occur } \\
\text { frequently }\end{array}$ \\
\hline RV & RNA & 1 day & $7-14$ days & common \\
\hline $\begin{array}{l}\text { HCOV 229E, } \\
\text { OC43, NL63 }\end{array}$ & RNA & 2-5 days & unknown & common \\
\hline hMPV & RNA & 3-5 days & $\begin{array}{l}7-14 \text { days } \\
\text { up to weeks to months in } \\
\text { immunocompromised hosts }\end{array}$ & $\begin{array}{l}\text { common recurrent } \\
\text { infection; usually mild } \\
\text { or asymptomatic }\end{array}$ \\
\hline FLU A, B & RNA & $1-4$ days & 3-7 days & not common \\
\hline $\mathrm{HAdV}$ & DNA & 2-14 days & $\begin{array}{l}\text { unknown, } \\
\text { persistent and intermittent } \\
\text { up to months is common }\end{array}$ & common \\
\hline $\mathrm{HBOV}$ & DNA & Unknown & up to 75 days & common \\
\hline PIV $1,2,3,4$ & RNA & 2-4 days & $7-21$ days & unknown \\
\hline
\end{tabular}

a according to the American Academy of Pediatrics, Red Book(25) and Fields, Virology(26)

the "strongness" of the correlation found between two continuous variables that are tested. It is generally accepted that a rho of $0-0.19$ means a very weak, between 0.2-0.39 a weak, between 0.4-0.59 a moderate, between 0.6-0.79 a strong and between $0.8-1$ a very strong correlation. ${ }^{27}$

\section{RESULTS}

The detection rate using RT-PCR in all ARI episodes was $81.8 \%$. Single viral infections were detected in 342/582 (58.8\%) patients. Multiple viral infections were detected in $134 / 582(23 \%)$ patients of which $110 / 582$ (18.9\%) were dual-infections, 22/582 $(3.8 \%)$ were triple infections and $2 / 582(0.3 \%)$ were quadruple infections. Within the group of dual infections, RSV was found most frequently. CT values were available in 471 out of 476 patients (98.9\%). CT values ranged from 9.13 to 44.62 .

In single infections, there was a small, but statistically significant difference between median CT values of RSV for hospitalized versus non-hospitalized children (23.17 versus 24.57, p 0.04) (Table 2). For Human Coronavirus (HCoV), there was a moderate correlation between CT value and disease severity (rho -0.548, p 0.006). For influenza virus (FLU), there was a moderate correlation between CT value and length of oxygen use (rho 0.55, p 0.027).

In RSV-HCoV multiple infections, there was a moderate correlation between CT values of RSV and LOS (rho -0.526, p 0.021) (Table 2). This correlation was not found for single HCoV in the same children. In RSV-Rhinovirus (RV) multiple infections, there 


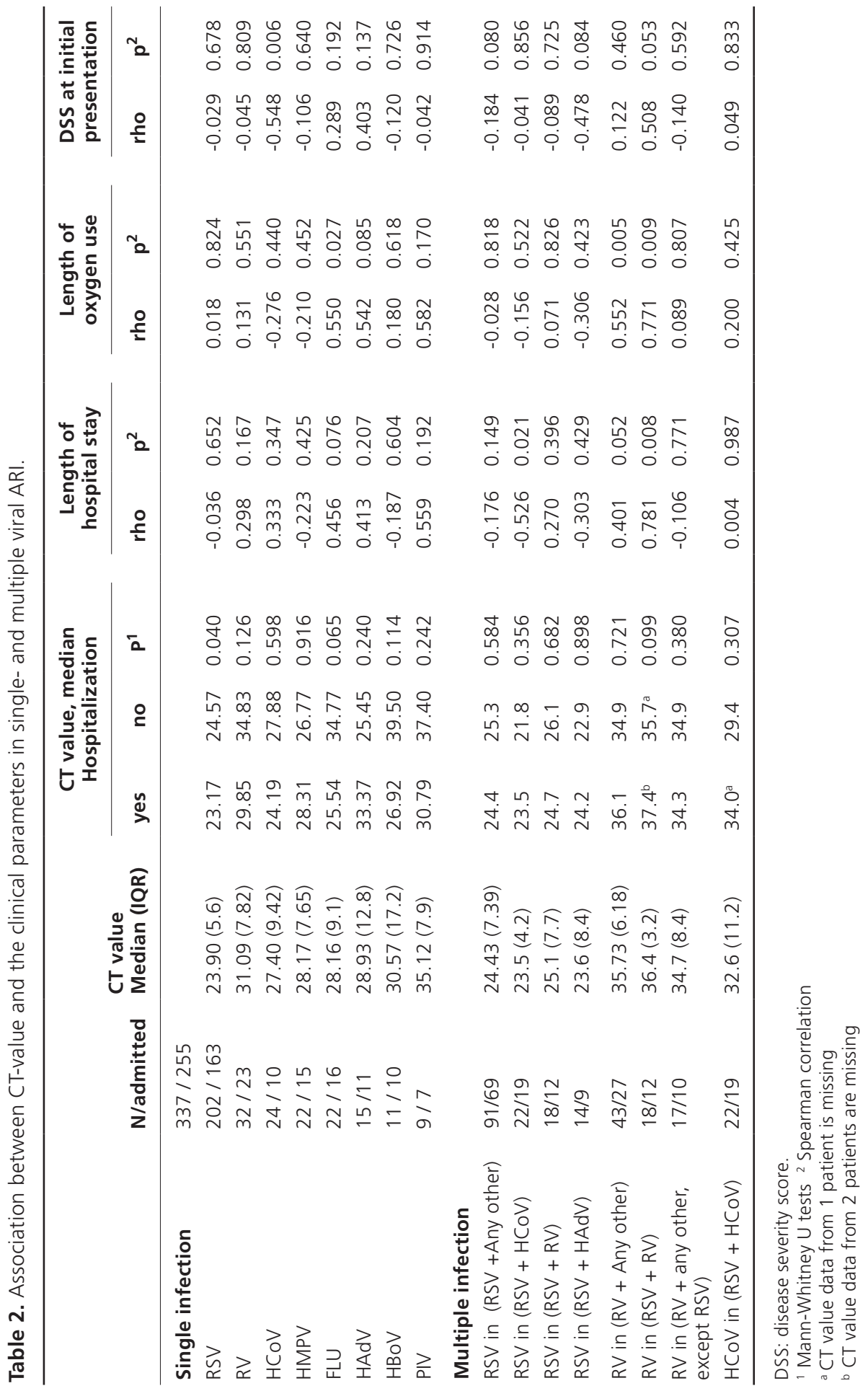


Table 3. Comparison of CT values of a specific virus in a single- or in a multiple infection.

\begin{tabular}{lllllll}
\hline $\begin{array}{l}\text { Mono } \\
\text { infection }\end{array}$ & N & $\begin{array}{l}\text { CT value } \\
\text { Median } \\
\text { (IQR) }\end{array}$ & Multiple infection & N & $\begin{array}{l}\text { CT value of first } \\
\text { mentioned virus } \\
\text { in the 4 } \mathbf{4}^{\text {th }} \text { column } \\
\text { Median (IQR) }\end{array}$ & $\begin{array}{l}\text { P } \\
\text { value }^{\text {a }}\end{array}$ \\
\hline RSV & 202 & $23.90(5.6)$ & RSV + any other virus & 92 & $24.43(7.39)$ & 0.127 \\
& & & RSV + HCoV & 23 & $23.1(4.2)$ & 0.812 \\
& & & RSV + RV & 18 & $25.1(7.7)$ & 0.126 \\
& & & RSV + HAdV & 14 & $23.6(8.4)$ & 0.704 \\
RV & 32 & $31.09(7.82)$ & RV + any other virus & 43 & $35.73(6.18)$ & 0.009 \\
HCoV & 24 & $27.40(9.42)$ & HCoV + any other virus & 47 & $31.60(9.81)$ & 0.015 \\
HMPV & 24 & $28.17(7.65)$ & HMPV + any other virus & 20 & $26.78(13.71)$ & 0.821 \\
FLU & 23 & $28.16(9.1)$ & FLU + any other virus & 13 & $25.37(7.46)$ & 0.749 \\
HAdV & 15 & $28.93(12.8)$ & HAdV + any other virus & 32 & $32.33(9.89)$ & 0.460 \\
HBoV & 11 & $30.57(17.2)$ & HBoV + any other virus & 14 & $32.05(10.7)$ & 0.120 \\
PIV & 9 & $35.12(7.9)$ & PIV + any other virus & 20 & $41.82(5.51)$ & 0.019 \\
\hline
\end{tabular}

a Mann-Whitney $U$ test

was a strong correlation between CT values of RV and LOS (rho 0.781, p 0.008) and between CT values of RV and length of oxygen use (rho 0.771, p 0.009). In RV multiple infections in which RSV was excluded (RV + any other, except RSV), no significant correlations were found between $C T$ values of RV and clinical parameters. In RV- multiple infections ( $R V$ + any other virus, including RSV) there was a moderate correlation between the CT values of RV and length of oxygen use (rho 0.552, p 0.005). These correlations were not found for RSV in the same children.

For RV, HCoV and for parainfluenza virus (PIV), the median CT values in single infections were significantly lower than for multiple infections (Table 3). For RSV, no significant differences of median CT values were found between single and multiple infections.

\section{DISCUSSION}

In this study we explored whether CT value is a useful marker for disease severity in children with ARI. Pitfalls in the interpretation of viral load are to be found in five domains: the host, the virus, the manner in which samples are collected, the laboratory techniques and the statistical methods. Our study illustrates the difficulties to interpret $C T$ values in children with ARI in all these domains. Host factors will be influenced by underlying disease, or genetic factors which predispose to a more severe disease course. ${ }^{1-4}$ It is unknown whether the amount of virus in an individual plays an additional role in this context. We therefore suggest that CT values of different individuals do not reflect disease severity at the same level. 
Viral factors may also influence the interpretation of CT values. The period of viral shedding differs between viruses (Table 1). For example, RSV and Influenza virus can only be detected during a short timeframe and a positive test usually reflects active infection. Other viruses can be detected for a long time even when clinical symptoms are not present anymore. In HBoV infections a high rate of co-infection occurs ${ }^{28}$ and prolonged HBoV shedding is common. ${ }^{29-30}$ This is important in the interpretation of the test results with regard to the time of sampling: early or late in the disease period. Most RT-PCR studies are cross-sectional, based on one single nasal washing specimen sample in a period of clinical symptoms, while ideally, a rise and fall in CT value would be necessary to correlate CT value with disease course. The cross-sectional design of our study is a limitation with regard to this. Furthermore, respiratory pathogens may also be detected in asymptomatic children, probably reflecting the natural virus colonization or asymptomatic infection in an individual in a certain period..$^{31,32}$

Laboratory factors may also influence the outcome of viral load. Nasopharyngeal aspirates, washes, swabs and brushes are usually considered suitable for RT-PCR analysis. ${ }^{33}$ However, the sample size itself is difficult to quantify and some methods are more invasive than others. The quality and volume of nasal wash fluid and other samples (concentration of epithelial cells and/or leucocytes), may vary considerably. Most of the studies have not corrected for the amount of human DNA, epithelial cells or leucocyte counts in nasal wash specimen samples. This is also a limitation of our study. In an individual (adult) patient in our laboratory we found a 1000 fold difference in human DNA concentration between two broncho-alveolar lavage samples, taken by the same pulmonologist, potentially reflecting a similar difference in viral sample size (unpublished observation). Differences in the RT-PCR methods itself may influence sensitivity of the test too. The sensitivity of multiplex RT-PCRs is generally lower than that of single target PCRs. ${ }^{33}$ The efficiency of the first step of the RT-PCR procedure, nucleic acid extraction, may vary between samples with different composition and nucleic acid concentrations. The efficiency of both steps may vary considerably between different target sequences. A given RNA or DNA concentration may result into different $\mathrm{CT}$ values depending on the target sequence, on the reverse-transcription and polymerase enzymes, and on the reaction conditions used. Furthermore, RNA viruses have a linear amplification step during the reverse transcription before the (exponential) PCR reaction. Therefore, the CT-value as such cannot be used to determine which virus is most important in multiple viral infections. In addition, interpretation of differences in viral load between RNA and DNA is complicated (Table 1). Finally, cut-off values of CT in RT-PCR are also important. Karpinnen et al. found significant differences in the amount of virus between cases and controls, suggesting that cut-off levels for CT have to be defined in order to provide adequate interpretation of positive test results. ${ }^{34}$ The cut off value for a positive RT-PCR test result of 45 in our study is probably too high. 
The statistical method is important for a proper interpretation of the relation between viral load and disease severity. CT values and continuous clinical parameters with an abnormal distribution like LOS, length of oxygen use and DSS at initial presentation should be correlated with each other using Spearman correlation. We suggest that only statistically significant correlations with a rho $>0.6$ are relevant for clinical decision making. Studies on this topic, correlating CT values with disease outcome frequently lack information on Spearman's coefficient and should therefore be evaluated with much caution. We did not find a correlation between the CT value of RSV single infections and disease severity at initial presentation (rho -0.029, p 0.678, $n=202$ ), as was also reported by Houben et al. in children during their first respiratory tract infection in life (rho $-0.68, \mathrm{p} \mathrm{0.02,} n=11$ ). ${ }^{11}$ For $\mathrm{HCoV}$, the correlation between CT values and DSS was statistically significant. However, the Spearman's rho $(-0.548)$ indicates only a moderate correlation. We therefore do not consider this finding as relevant for clinical practice. The significant correlation between CT value and length of oxygen use in children with infection by influenza also had a moderate rho (rho 0.550, p 0.027), indicating little clinical importance. Besides these difficulties in the interpretation of rho values for continuous variables, statistically significant differences in dichotomous variables are sometimes not of clinical importance. We showed a statistically significant difference between median CT values of RSV single infection of hospitalized versus non-hospitalized children (23.17 versus 24.57, $p=0.040$ ). However, although this relation is statistically significant, the median CT values are close together and their interquartile ranges are overlapping (5.64 versus 5.14, data not shown in table). This does not help the clinician to discriminate between sick and non-sick children.

The correlation between CT values and clinical parameters is even more difficult to interpret in multiple infections. A strong correlation was found between $C T$ value of RV and LOS (rho 0.781, p 0.008) and length of oxygen use (rho 0.771, p 0.009) in RSV-RV multiple infections. This correlation was not found in RV single infections, suggesting that a low viral load of RV in RSV-RV multiple infections is correlated with a more severe disease course. In multiple infections including RV ( $R V+$ any other virus), the correlation between $C T$ value of RV and oxygen use was moderate (rho 0.552, p 0.005) and for LOS this relation was not significant. In multiple infections in which RV is included, but RSV is excluded (RV + any other virus except RSV), no relations between $C T$ values of $R V$ and clinical parameters were found. A recent study suggests that the presence of RSV reduces the probability of RV infection, but if a co-infection occurs, both viruses cause clinical symptoms. ${ }^{35}$ Unfortunately, CT values were not reported in this study. Our study adds that in case of these RSV-RV multiple infections, a more severe disease course may be correlated with a low viral load of RV. As our results are based upon data from only 12 hospitalized children, this observation should be confirmed in further studies. 
The viral load in single infections with RV, HCoV and PIV was significantly higher than for the same viruses in multiple infections (Table 3). This may suggest that RV, $\mathrm{HCOV}$ and PIV are bystanders in multiple infections. Thus far, there are no studies with appropriate sample sizes that show that finding multiple viruses in a patient is accidental, season-related, or the result of true synergism between viruses. ${ }^{31}$

\section{CONCLUSIONS}

In children with RSV-RV multiple infections, a more severe disease course may be correlated with a low viral load of RV. Furthermore, the viral load in single infections with RV, HCoV and PIV was significantly higher than for the same viruses in multiple infections, suggesting that these viruses are bystanders in multiple infections. These observations need to be confirmed in studies with a larger cohort in future.

However, for daily clinical practice at this moment, we conclude that viral load is not a helpful determinant to assess disease severity in children with ARI. Even when the relation between viral load of a single virus and clinical outcome is statistically significant, the Spearman's rho is often weak and therefore findings are unlikely to be of clinical importance. In multiple infections, viral load does not help the clinician to differentiate between disease causing virus and innocent bystanders in a single patient, as viral loads of different viruses may not be compared with each other, because technical specifications of RT-PCR assays differ between viruses.

\section{ETHICAL APPROVAL}

Obtained from the national Medical Ethics Committee.

\section{ACKNOWLEDGEMENTS}

We thank P. Goswami, MD for critically reviewing the manuscript in the English language. 


\section{REFERENCES}

1. E.E. Wang, B.J. Law, D. Stephens, Pediatric Investigators Collaborative Network on Infections in Canada (PICNIC) prospective study of risk factors and outcomes in patients hospitalized with respiratory syncytial viral lower respiratory tract infection, J. Pediatr. 126 (February (2)) (1995) 212-219.

2. H.K. Brand, G. Ferwerda, F. Preijers, R. de Groot, C. Neeleman, F.J. Staal, et al., CD4+ T-cell counts and interleukin-8 and CCL-5 plasma concentrations discriminate disease severity in children with RSV infection, Pediatr. Res. 73 (February (2)) (2013) 187-193.

3. H.K. Brand, I.M.L. Ahout, D. de Ridder, A. van Diepen, Y. Li, M. Zaalberg, et al., Olfactomedin 4 serves as a marker for disease severity in pediatric respiratory syncytial virus (RSV) infection, PLoS One 10 (7) (2015) e0131927.

4. A. Mejias, B. Dimo, N.M. Suarez, C. Garcia, M.C. Suarez-Arrabal, T. Jartti, et al., Whole blood gene expression profiles to assess pathogenesis and disease severity in infants with respiratory syncytial virus infection, PLoS Med. 10 (November (11)) (2013) e1001549.

5. C.B. Hall, G.A. Weinberg, M.K. Iwane, A.K. Blumkin, K.M. Edwards, M.A. Staat, et al., The burden of respiratory syncytial virus infection in young children, N. Engl. J. Med. 360 (February (6)) (2009) 588-598.

6. Y. Deng, X. Gu, X. Zhao, J. Luo, Z. Luo, L. Wang, et al., High viral load of human bocavirus correlates with duration of wheezing in children with severe lower respiratory tract infection, PLoS One 7 (3) (2012) e34353.

7. J.P. DeVincenzo, T. Wilkinson, A. Vaishnaw, J. Cehelsky, R. Meyers, S. Nochur, et al., Viral load drives disease in humans experimentally infected with respiratory syncytial virus, Am. J. Respir. Crit. Care Med. 182 (November (11)) (2010) 1305-1314.

8. I. Fodha, A. Vabret, L. Ghedira, H. Seboui, S. Chouchane, J. Dewar, et al., Respiratory syncytial virus infections in hospitalized infants: association between viral load, virus subgroup, and disease severity, J. Med. Virol. 79 (December (12)) (2007) 1951-1958.

9. J.A. Fuller, M.K. Njenga, G. Bigogo, B. Aura, M.O. Ope, L. Nderitu, et al., Association of the $C T$ values of real-time PCR of viral upper respiratory tract infection with clinical severity, Kenya, J. Med. Virol. 85 (May (5)) (2013) 924-932.

10. K. Hasegawa, T. Jartti, J.M. Mansbach, F.R. Laham, A.M. Jewell, J.A. Espinola, et al., Respiratory syncytial virus genomic load and disease severity among children hospitalized with bronchiolitis: multicenter cohort studies in the United States and Finland, J. Infect. Dis. 211 (May (10)) (2015) 1550-1559.

11. M.L. Houben, F.E. Coenjaerts, J.W. Rossen, M.E. Belderbos, R.W. Hofland, J.L. Kimpen, et al., Disease severity and viral load are correlated in infants with primary respiratory syncytial virus infection in the community, J. Med. Virol. 82 (July (7)) (2010) 1266-1271.

12. C. Scagnolari, F. Midulla, C. Selvaggi, K. Monteleone, E. Bonci, P. Papoff, et al., Evaluation of viral load in infants hospitalized with bronchiolitis caused by respiratory syncytial virus, Med. Microbiol. Immunol. 201 (August (3)) (2012) 311-317.

13. A. Takeyama, K. Hashimoto, M. Sato, T. Sato, S. Kanno, K. Takano, et al., Rhinovirus load and disease severity in children with lower respiratory tract infections, J. Med. Virol. 84 (July (7)) (2012) 1135-1142.

14. S. Utokaparch, D. Marchant, J.V. Gosselink, J.E. McDonough, E.E. Thomas, J.C. Hogg, et al., The relationship between respiratory viral loads and diagnosis in children presenting to a pediatric hospital emergency department, Pediatr. Infect. Dis. J. 30 (February (2)) (2011) e18-e23. 
15. B. Zhao, X. Yu, C. Wang, Z. Teng, C. Wang, J. Shen, et al., High human bocavirus viral load is associated with disease severity in children under five years of age, PLoS One 8 (4) (2013) e62318.

16. A. Franz, O. Adams, R. Willems, L. Bonzel, N. Neuhausen, S. Schweizer-Krantz, et al., Correlation of viral load of respiratory pathogens and co-infections with disease severity in children hospitalized for lower respiratory tract infection, J. Clin. Virol. 48 (August (4)) (2010) 239-245.

17. R.R. Jansen, J. Schinkel, I. Dek, S.M. Koekkoek, C.E. Visser, M.D. de Jong, et al., Quantitation of respiratory viruses in relation to clinical course in children with acute respiratory tract infections, Pediatr. Infect. Dis. J. 29 (January (1)) (2010) 82-84.

18. F.M. Moesker, J.J. van Kampen, A.M. van Rossum, H.M. de, M.P. Koopmans, A.D.M.E. Osterhaus, et al., Viruses as sole causative agents of severe acute respiratory tract infections in children, PLoS One 11 (3) (2016) e0150776.

19. J.C. Van Leeuwen, L.K. Goossens, R.M. Hendrix, J. Van Der Palen, A. Lusthusz, B.J. Thio, Equal virulence of rhinovirus and respiratory syncytial virus in infants hospitalized for lower respiratory tract infection, Pediatr. Infect. Dis. J. 31 (January (1)) (2012) 84-86.

20. P.F. Wright, W.C. Gruber, M. Peters, G. Reed, Y. Zhu, F. Robinson, et al., Illness severity, viral shedding, and antibody responses in infants hospitalized with bronchiolitis caused by respiratory syncytial virus, J. Infect. Dis. 185 (April (8)) (2002) 1011-1018.

21. H.K. Brand, R. de Groot, J.M. Galama, M.L. Brouwer, K. Teuwen, P.W. Hermans, et al., Infection with multiple viruses is not associated with increased disease severity in children with bronchiolitis, Pediatr. Pulmonol. 47 (April (4)) (2012) 393-400.

22. E.A. Goka, P.J. Vallely, K.J. Mutton, P.E. Klapper, Single, dual and multiple respiratory virus infections and risk of hospitalization and mortality, Epidemiol. Infect. 143 (January (1)) (2015) 37-47.

23. Y. Harada, F. Kinoshita, L.M. Yoshida, M. Minh IN. Suzuki, K. Morimoto, et al., Does respiratory virus coinfection increases the clinical severity of acute respiratory infection among children infected with respiratory syncytial virus? Pediatr. Infect. Dis. J. 32 (May (5)) (2013) 441-445.

24. J.O. Wishaupt, A. Russcher, L.C. Smeets, F.G.A. Versteegh, N.G. Hartwig, Clinical impact of RT-PCR for pediatric acute respiratory infections: a controlled clinical trial, Pediatrics 128 (November (5)) (2011) e1113-e1120.

25. J.E. Gern, M.S. Martin, K.A. Anklam, K. Shen, K.A. Roberg, K.T. Carlson-Dakes, et al., Relationships among specific viral pathogens, virus-induced interleukin-8, and respiratory symptoms in infancy, Pediatr. Allergy Immunol. 13 (December (6)) (2002) 386-393.

26. J.O. Wishaupt, E.A.N. van den Berg, T. van Wijk, T. van der Ploeg, F.G.A. Versteegh, N.G. Hartwig, Paediatric apnoeas are not related to a specific respiratory virus, and parental reports predict hospitalisation, Acta Paediatr. 105 (May (5)) (2016) 542-548.

27. The BMJ. Online source Correlation and Regression: http://www.bmj.com/ about-bmj/ resources-readers/publications/statistics-square-one/11- correlation-and-regression. 2016. Ref Type: Online Source.

28. O. Schildgen, A. Muller, T. Allander, I.M. Mackay, S. Volz, B. Kupfer, et al., Human bocavirus: passenger or pathogen in acute respiratory tract infections? Clin. Microbiol. Rev. 21 (April (2)) (2008) 291-304 (table).

29. E.T. Martin, J. Kuypers, J.P. McRoberts, J.A. Englund, D.M. Zerr, Human bocavirus 1 primary infection and shedding in infants, J. Infect. Dis. 212 (August (4)) (2015) 516-524.

30. M.L. von Linstow, M. Hogh, B. Hogh, Clinical and epidemiologic characteristics of human bocavirus in Danish infants: results from a prospective birth cohort study, Pediatr. Infect. Dis. J. 27 (October (10)) (2008) 897-902. 
31. A.A. Bosch, G. Biesbroek, K. Trzcinski, E.A. Sanders, D. Bogaert, Viral and bacterial interactions in the upper respiratory tract, PLoS Pathog. 9 (January (1)) (2013) e1003057.

32. M.M. van der Zalm, B.E. van Ewijk, B. Wilbrink, C.S. Uiterwaal, T.F. Wolfs, C.K. van der Ent, Respiratory pathogens in children with and without respiratory symptoms, J. Pediatr. 154 (March (3)) (2009) 396-400 (400).

33. T. Jartti, M. Soderlund-Venermo, K. Hedman, O. Ruuskanen, M.J. Makela, New molecular virus detection methods and their clinical value in lower respiratory tract infections in children, Paediatr. Respir. Rev. 14 (March (1)) (2013) 38-45.

34. R.R. Jansen, J. Wieringa, S.M. Koekkoek, C.E. Visser, D. Pajkrt, R. Molenkamp, et al., Frequent detection of respiratory viruses without symptoms: toward defining clinically relevant cutoff values, J. Clin. Microbiol. 49 (July (7)) (2011) 2631-2636.

35. S. Karppinen, L. Toivonen, L. Schuez-Havupalo, M. Waris, V. Peltola, Interference between respiratory syncytial virus and rhinovirus in respiratory tract infections in children, Clin. Microbiol. Infect. 22 (February (2)) (2016) 208-216. 


\section{SUPPLEMENTARY INFORMATION}

Supplementary Table 1. Modified disease severity score after Gern ${ }^{25}$

\begin{tabular}{ll}
\hline Symptom & point score \\
\hline Fever & 1 \\
Cough & 1 \\
Rhinorrhea & 1 \\
Duration of illness $>4$ days & 1 \\
Apnea & 3 \\
Wheezing & 5 \\
Cyanosis & 5 \\
Retractions & 5 \\
Tachypnea & 5 \\
\hline
\end{tabular}

a Score 0-7 represents mild disease, 8-18 moderate disease and 19-27 severe disease. 



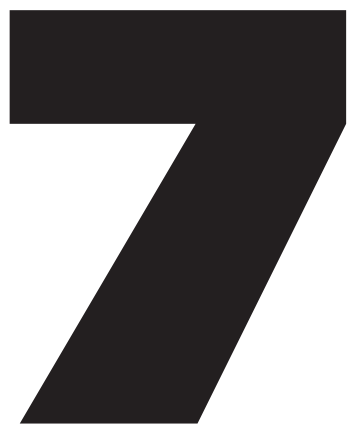




\title{
GENERAL DISCUSSION, SUMMARIZING CONCLUSIONS AND FUTURE PERSPECTIVES
}

\author{
Partly adapted from \\ "PCR testing for Paediatric Acute Respiratory Tract Infections", \\ Jérôme O. Wishaupt, Florens G.A. Versteegh, Nico G. Hartwig, \\ Paediatric Respiratory Reviews 2015;16(1):43-48
}





\section{GENERAL DISCUSSION}

Worldwide, acute respiratory tract infection (ARI) is the most common illness experienced by people. In the Western world ARI is the leading cause of hospitalization in young children". One might expect that a quick and reliable diagnosis can be confirmed by the use of microbiological techniques. Analysis of microbiological techniques may potentially help to avoid complications and to reduce unnecessary use of antibiotics. However, thusfar the diagnosis of a disease entity such as bronchiolitis can only be obtained based on the history of the parents or caretakers and by repeated observations over time ${ }^{2}$.

Since many years, assessment of disease severity in patients with ARI is supported by transcutaneous oxygen measurement and conventional viral diagnostics in children with ARI at the emergency department (ED) or after admission to the hospital. In the last decade, reverse transcriptase real-time polymerase chain reaction (RT-PCR) assays have been introduced in many hospitals. However, the role of these new molecular diagnostic techniques to improve patient care and to facilitate clinical decision making in children with ARI was not determined prior to introduction of these techniques. A gold standard in diagnostic techniques has not yet been established.

In this thesis, we evaluated the role of viral diagnostics in children with ARI, with a special focus on the role and position of the RT-PCR. A pilot study was performed to optimise the way how to collect clinical data with standardized case report forms and to optimize logistics of rapid reporting of laboratory results to the paediatrician.

The primary goal of the study was to evaluate the diagnostic yield of RT-PCR assays for children with ARI in general hospital settings and the effects on patient care of rapid communication of the results to the paediatrician. This was measured based on days of hospital stays and antibiotic use. To do so, a controlled clinical trial was performed in two Dutch hospitals during two winter seasons. Clinical data and nasal wash specimens of 582 children with respiratory symptoms were prospectively collected. RT-PCR measurements on samples from both hospitals were performed in one laboratory. The RT-PCR results were communicated to the clinicians within 12-36 hours in the intervention group and after four weeks in the control group.

The same large clinical database of RT-PCR established diagnoses was used to study the secondary goals of this thesis. They comprise a) the risk of apnoeas in young children with ARI, b) the incidence and relevance of double/mixed infections, c) the relevance of viral load related to disease severity and d) the incidence of pertussis.

\section{The most important findings of the studies in this thesis}

RT-PCR testing generates a high yield of viral diagnoses, but rapid communication to the paediatrician does not lead to changes in patient management.

Children with different single virus RT-PCR results do significantly differ with respect to some clinical aspects, but no recognizable clinical pattern per virus group was present. 
Single- and multiple viral ARI do not significantly differ with respect to clinical outcome and patient management.

Apnoeas in paediatric ARI occur irrespective of the isolated micro-organism(s).

Parental reported apnoeas are a major warning sign; if parents or caretakers reported apnoeas at home, also apnoeas occurred in these children during hospitalization.

Pertussis in children sometimes mimics viral ARI. If diagnosing pertussis is based on clinical suspicion alone without laboratory confirmation, about 1 in 5 cases is missed.

Paroxysmal cough is not solely associated with Bordetella pertussis, but also with ARI caused by other bacteria and viruses. In addition, absence of paroxysmal cough does not exclude pertussis.

Although some statistically significant correlations between viral load and clinical parameters were found in children with single and multiple viral ARI, viral load does not allow an accurate assessment of disease severity in these children.

In children with RSV-Rhinovirus (RV) double infections, a strong correlation was found between the CT value of RV and length of hospital stay (LOS) and length of oxygen use. This correlation was not found in RV single infections, suggesting that a low viral load of RV in mixed RSV-RV infections is correlated with a more severe disease course. This suggests an interaction between these two viruses in patients with ARI.

The viral load in single RV infections, Human Coronavirus (HCoV) and Parainfluenza virus (PIV) was significantly higher than the viral load for the same viruses in mixed infections, suggesting that these viruses may be innocent bystanders in these situations.

In general, viral load cannot be used in multiple infections to differentiate between disease causing virus and 'innocent' viruses.

\section{CLINICAL IMPACT OF RT-PCR IN PAEDIATRIC ARI Use of RT-PCR in general paediatrics}

In a prospective controlled clinical trial, we showed that RT-PCR testing generates a high yield of viral diagnoses, but that rapid communication to the paediatrician did not lead to changes in patient management (Chapter 2 ). The role of viral diagnostics has been the subject of debate in many clinical papers, frequently to study its potential to reduce hospital related costs like hospital stay and medical costs and its potential to reduce unnecessary antibiotic use. In an adult population, implementation of RT-PCR in patients with lower respiratory tract infection increased the diagnostic yield, but did not reduce antibiotic use or costs ${ }^{3}$. In a multicentre paediatric study, interviewing 
medical doctors on fictional ARI cases, use of RT-PCR decreased antibiotic use ${ }^{4}$. However, in real life, the same physicians did not alter their antibiotic prescriptions based on the results of RT-PCR. In a Cochrane review including four randomised controlled trials that evaluated the impact of rapid viral tests in children with ARI in an emergency department (ED), rapid viral testing by immunofluorescence or PCR did not lead to changes in antibiotic use, length of ED visits, blood or urine testing, but did lower the rates of chest radiographs ${ }^{5}$. The authors stated that routine viral testing in the ED is promising as a means to reduce antibiotic use, but there is yet insufficient evidence to support this practice; large trials are needed with a focus on patient management with respect to the results. In a recent retrospective study evaluating clinical differences between RSV and non-RSV patients, enzyme linked immunoassay and/or PCR testing did not help in clinical management decisions and seemed insufficient to predict outcome at an individual level ${ }^{6}$. In another recent retrospective study of 177 children with ARI in a general hospital, antibiotic management was not influenced after detecting a viral respiratory pathogen, although the authors state that routine testing of common respiratory pathogens could lead to a better understanding of their role in disease in children with respiratory symptoms ${ }^{7}$. In a 6-year prospective study of children with community acquired pneumonia (CAP), designed to describe the frequency of respiratory viruses, antibiotics were prescribed less frequently in viral positive versus negative children, but only when the children were $>18$ months old 8 .

Based on the above literature, routine testing for viruses using RT-PCR in general patient management in children with ARI cannot be recommended. In our prospective controlled clinical trial, we have confirmed this finding from previous studies. It is important to know that the attending physicians in our study were not instructed by the investigators to change their management in any way after the results were reported. For example, the paediatricians were aware of the low incidence of bacterial co-infection in viral confirmed ARI, but the decision whether or not to stop an antibiotic regimen after a positive viral test result was not dictated by the investigators. Our findings are also in agreement with the statement of the American Association of Pediatrics (AAP), not to recommend routine viral testing for standard ARI cases, unless the physician is willing to change his patient management based on the results². For example, if antibiotics are started in children with bronchiolitis, prior to viral test results are available, the physician should stop these antibiotics in case a test result turns out to be positive.

\section{Use of RT-PCR in selected patient groups}

Children admitted to paediatric intensive care units (PICU) were not included in our studies. These children with respiratory failure induced by viral infection and admitted to PICUs for mechanical ventilation, frequently have concomitant bacterial infections $^{9}$. Use of an extended RT-PCR panel of respiratory pathogens seems to be 
justified in those conditions to determine the causing micro-organisms. Children with underlying immunodeficiencies are susceptible to severe complications of viral infections. Indications for RT-PCR diagnostics in children with hematologic malignancies, hematopoietic stem cell transplantation, solid organ transplantation, premature infants and children with cystic fibrosis were also not within the scope of this thesis. Data concerning these patient groups have been reviewed by Vallieres and Renaud ${ }^{10}$.

\section{Use of RT-PCR in infection control}

Infection control measurements are necessary to prevent nosocomial infections and also to protect health care personnel. Isolation or cohorting is a well-established policy to prevent nosocomial infections. The epidemiology of many nosocomial respiratory infections is not well known. For RSV, the incidence of nosocomial spread seems low ${ }^{11}$. Although information about management of outbreaks is sparse and not well documented, normal prevention measurements appear to be effective ${ }^{12}$. For cohorting, rapid testing for RSV has shown to be a safe, cost-effective and efficient way to allow optimal use of the (limited number of) hospital beds ${ }^{13}$. However, we propose that rapid antigen tests such as direct immunofluorescent antibody tests are not a useful tool to make decisions about cohorting, since these tests may have a high proportion of false negatives. RT-PCR is much more sensitive and specific, but the turnaround time is not sufficient to act in time to implement infection control measurements at admission. We also question whether cohorting should or can be based on RT-PCR results of a limited number of viruses. Mixed infections occur in a substantial proportion of children and whether these children spread other nondetected viruses during cohorting is not yet clear. The risk of cross-infection in children sharing a room was recently studied in a prospective observational cohort study of 48 children with bronchiolitis. Room sharing between RSV-positive and RSV-negative children on the first day of admission did not influence the risk of co-infection ${ }^{11}$.

\section{Use of RT-PCR in epidemiologic surveillance}

Special indications to perform RT-PCR as part of epidemiologic surveillance programs were also outside the scope of our studies. Examples are the worldwide search for SARS and MERS coronaviruses, well known for their febrile and atypical pneumonia and the dramatic course in a large number of the affected patients ${ }^{14-18}$. Other national and WHO-supported surveillance programs include seasonal influenza viruses. Currently, the 'bird flu' influenza A subtype H7N9 is of special interest for its infection of humans and possible easy transmission from wild birds to humans ${ }^{19}$.

\section{Conclusions}

RT-PCR has shown superior sensitivity and specificity, compared with conventional viral diagnostics. Based on our studies, we do not recommend excluding RT-PCR in daily 
paediatric practice. However, we advise to re-evaluate its position. As we may argue that it is not clinically relevant to perform routine RT-PCR testing for all respiratory viruses for every patient with $A R I$, the question raises which viruses should be added in RT-PCR panels and which should not. And which patients should be tested? To answer this question, several additional studies were performed (chapter 3-6).

\section{SINGLE- AND MULTIPLE RT-PCR TEST RESULTS}

Which assays should be added in RT-PCR panels for children with ARI? To answer this question, we first need to know what it means to have a positive test result for a certain virus. Is it helpful to know whether an infection is caused by virus $A$ or by virus B in terms of disease severity and outcome? And how to interpret negative test results or multiple test results in one single nasal wash specimen (NWS)? To answer these questions, we investigated the correlation between clinical data and RT-PCR results in children with single- and multiple viral ARI (chapter 3).

\section{Single infections}

It is generally accepted that some viruses, like RSV seem to have a greater disease burden than other viruses. And for influenza, nobody will doubt its great burden of disease worldwide. Literature on clinical aspects of individual viruses is very extensive, as is outlined in chapter 1 of this thesis. However, comparison of disease severity of these individual viruses is complex, since studies on this subject differ with regard to design, age at inclusion, recruitment criteria, the manner of data collection, assay sensitivity and the type of viruses studied ${ }^{20}$. Moreover, co-infections are not always excluded in studies regarding disease severity of infection with these individual viruses. In order to study these individual differences, we excluded co-infections (chapter 3). We found that children with single virus groups did significantly differ from each other with regard to several clinical findings, but a recognizable clinical pattern per virus group was missing. Disease (severity), management and outcome were not associated with a specific virus. LOS was determined by duration of extra oxygen supply or need for nebulizer therapy. The question which viruses should be added to a RT-PCR panel cannot be answered on the basis of differences in disease severity of infection with these individual viruses.

\section{Multiple viral infections / viral-viral interactions}

The proportion of children with viral co-infections detected by RT-PCR has increased to $43 \%{ }^{21}$. We observed in our study that there is no relation between multiple respiratory viral infections and disease severity. This finding is in agreement with that observed in other studies ${ }^{22-26}$. However, others report a higher disease severity in children with multiple respiratory infections ${ }^{27-29}$. And some investigators observed a less severe disease course in patients with multiple viral infections ${ }^{30-32}$. Although meta analyses may help 
to make more definitive conclusions, they are difficult to perform, since studies differ too much with respect to design and outcome parameters ${ }^{20}$. In a recent systematic review, the role of co-infection as a risk factor for severe viral ARI was not clear ${ }^{33}$. The authors attribute this conflict in outcomes not only to the differences in seasons and study periods, but also to the statistical methods used: bias towards the null is possible in studies where only crude data were analysed. Future studies should employ stratified analyses and explore the effect of specific pairs of viruses. Indeed, some investigators suggest that viral-viral interactions do exist: in a mice model, the growth of RSV was blocked by competitive infection with FLU ${ }^{34}$. Epidemiologic data also suggest the presence of a competition between these viruses; when rates of RSV are high, influenza infections were low and vice-versa ${ }^{35}$. Recently the observed incidence of co-infection of RSV and FLU was less than the expected incidence, even when both viruses were co-circulating ${ }^{36}$. FLU may also interact with RV. A French study showed an unexpectedly slow onset of the FLU A (H1N1) epidemic in 200937. The authors attributed this finding to an intense circulation of RV. Another group tried to explain these viral competitions by a mathematical model: during co-infections, one virus can block another simply by being the first to infect the available host cells without need for viral interference through immune response interactions ${ }^{38}$. In our own study, we did not find differences in clinical symptoms and management between the five most common dual viral combinations (RSV/HCoV, RSV/RV, RSV/HAdV, RSV/hMPV, RSV/PIV). However, when we applied cycle threshold values (CT value) of RT-PCR in our analysis, we found a strong correlation between the CT value of RV and LOS and length of oxygen use in children with RSV-RV multiple infections (chapter 6). This correlation was not found in RV single infections, suggesting that a low viral load of $\mathrm{RV}$ in RSV-RV double infection is correlated with a more severe disease course. This finding supports the idea that viral-viral interactions do exist. The mechanisms that may influence disease severity in multiple infections are not yet well understood and more research is needed on this subject.

\section{Viral - bacterial co-infections / interactions}

We did not focus in our studies on the presence or absence of viral - bacterial coinfections and bacterial cultures were not standard procedures. The risk of bacterial co-infection in children with RSV infections seems limited. However, in a study of 66 hospitalized patients with RSV, bacteraemia was found in $10.6 \%^{39}$. In those patients with positive bacterial results, there was a previous suspicion of bacterial super-infection and disease severity was significantly higher than in children with negative bacterial results. In patients admitted to a PICU for severe RSV up to $40 \%$ of children was infected with bacteria in their lower airways ${ }^{40}$. Nevertheless, this does not proof that children with bronchiolitis due to RSV have a high susceptibility for bacterial infection. Indeed, in a systematic review in young children with bronchiolitis, the incidence of bacteraemia or meningitis was extremely rare ${ }^{41}$. A recently updated 
Cochrane review of children with bronchiolitis also found a very low risk for bacterial co-infection and concluded that there was no evidence to support the use of antibiotics. Future research on the use of antibiotics should focus on small subgroups of patients, like patients with respiratory failure at PICUs, cyanotic congenital heart disease or patients with nosocomially acquired RSV ${ }^{42}$.

There are indications that viruses and commensal bacteria do interact with each other. In children with clinically confirmed bronchiolitis, viral infection was negatively associated with pneumococcal colonization of the upper airways ${ }^{43}$. There seems to be a complex relationship between nasopharyngeal carriage of pneumococci and disease course of RSV bronchiolitis ${ }^{44}$. The interaction between RSV and nasopharyngeal microbiota may modulate the host immune response and potentially affect clinical disease severity in children with RSV ${ }^{45}$. Another study showed different nasopharyngeal microbial profiles between children with RSV- and with RV related ARI46.

In patients with FLU, an increased susceptibility for bacterial infection has been documented many years ago. The occurrence of secondary bacterial pneumonia was the cause of death in many cases of the 1918-1919 influenza pandemic. In children with FLU, one should be aware of severe secondary bacterial infection, especially with Staphylococcus aureus and Streptococcus pneumoniae ${ }^{47}$.

\section{Negative RT-PCR test results}

RT-PCR assays are highly sensitive and specific ${ }^{48}$. In our study, 476 out of 582 NWS (82\%) were positive for one or more pathogens. The remaining 106 NWS (18\%) had negative test results. In these patients, the disease severity score (DSS), the number of patients with fever, LOS, the days of oxygen supply and the days of antibiotic therapy were significantly lower compared to patients with positive test results (Chapter $\mathbf{3}$, Table 6). All patients in our study presented to the paediatrician with respiratory symptoms. Within the 106 patients with negative RT-PCR test results, 23 patients were diagnosed at discharge as "no respiratory infection". Clinical diagnoses of these children were breath holding spells $(n=1)$, respiratory arrest most likely due to gastrooesophageal reflux $(n=8)$, parechovirus meningitis $(n=1)$, echo virus infection $(n=1)$, rotavirus infection $(n=1)$, viral infection / no specific diagnosis $(n=11)$. As a result, the number of patients with a clinical diagnosis of ARI at discharge and a negative RT-PCR test result was $106-23=83$. (83 out of $582=14 \%$ ).

There are several host-, viral-, and laboratory factors that may influence the CT value of RT-PCR assays and thus potentially contribute to negative test results. These factors are outlined in chapter $\mathbf{6}$. Despite these factors, we cannot exclude that with new techniques like "next-generation" sequencing or using the "virome capture sequencing platform for vertebrate viruses" (VirCapSeq-VERT), described in $2015^{49}$, some of our negative-tested NWS would have shown a positive test result. Unfortunately, we are not able to perform this new technique, since no NWS material is left. 
Finally, using RT-PCR, one only gets results from viruses that are included in the test panel. For example, Enterovirus D68 and the polyomaviruses WU and KI were not included in our test panel. As described in the introduction (chapter 1), the incidence figures of these viruses are unknown and we cannot exclude that some of the children with negative RT-PCR test results might have been positive for one of these viruses. It is also possible that some children with a negative RT-PCR test results are infected with new viruses that are thus far undiscovered.

\section{APNOEAS}

Apnoeas are a severe complication of ARI in young children and known risk factors are prematurity, an early postnatal onset, a history of apnoea or cyanosis and comorbidity, especially of the respiratory tract ${ }^{50-55}$. We investigated the effect of individual viruses on the occurrence of apnoeas (chapter 4). Apnoeas occurred irrespective of the isolated microorganism and we recommend not to use viral testing for RSV to identify children at risk for hospitalisation. Our study underlines the importance of parental reported apnoeas, as it predicts apnoeas to occur in the hospital as well.

Studies on this subject are difficult to interpret, mainly because definitions of apnoeas differ and strict registration of apnoeas by continuous monitoring of vital parameters is less accurate than in PICU settings. The same problem holds true for a recent study showing no effect of a single dose of caffeine to prevent apnoeas in children with ARI in an emergency department centre in Qatar56: 'witnessed apnoeas at home are subjective and cardiorespiratory events are not collected on signal analysis ${ }^{\prime 57}$. As most children with apnoeas are not admitted to PICUs, but to general wards, these circumstances must be addressed in the future.

\section{PERTUSSIS}

As is stated before, using RT-PCR, one only gets results based on what is included in the test panel. In chapter 5, we discussed the problem of missed diagnoses of pertussis in young children with ARI. The clinical picture of pertussis ranges from the classical presentation with paroxysmal cough and severe disease to mild disease with only rhinitis which may mimic viral ARI. We showed that about 1 in 5 cases pertussis diagnosis is missed when it is based on clinical suspicion alone. The same problem of missed pertussis cases is evident in a recent meta-analysis studying the prevalence of atypical pathogens in patients with cough and community-acquired pneumonia. They found a high prevalence of Bordetella pertussis in studies where epidemiologic surveillance data were available and all children were tested for this pathogen ${ }^{58}$. For individual patient management, missed pertussis cases could be a problem, as antimicrobial therapy administered in an early stage of pertussis may shorten the duration of symptoms ${ }^{59}$. 
In addition to managing the individual patient, missed pertussis cases are a threat for the population as well, as untreated patients will spread pertussis. We support the recommendations already advocated by the Global Pertussis Initiative Round Table Meeting ${ }^{60}$, to perform more frequently laboratory confirmation of pertussis in order to control the spread within the population. At this point, one should be aware that besides Bordetella pertussis, other Bordetella species are associated with ARI too: Bordetella parapertussis, Bordetella holmesii, and Bordetella bronchiseptica. The RT-PCR target IS481 does not differentiate between these species. As the role of these different species is still uncertain, further research is needed to explore whether species specific targets are needed ${ }^{61,62}$.

Studies investigating cost-effectiveness of more frequent laboratory diagnostics on less frequently missed pertussis cases in order to prevent spread of pertussis in the population should be performed too.

\section{VIRAL LOAD}

Another question raised by us was to explore the relation between viral load and disease severity in children with ARI. Some investigators suggest a positive relationship ${ }^{63-72}$, although others don't $t^{73-78}$. We tried to answer the question whether the cycle threshold value of RT-PCR is useful in paediatric clinical practice. Indeed we found some correlations between $C T$ values and clinical parameters in patients with single and multiple viral ARI (chapter 6). However, individual differences in host, viral and laboratory factors complicate the interpretation of these statistically significant findings. A correct use of the statistical method itself is also a challenge in this field.

In paediatric practice, viral diagnostics are mostly used as single measurement at first presentation at the emergency room or outpatient clinic. As viral load is a dynamic process, these circumstances are substandard for studying the relation between viral load and disease severity. In the future, studies with longitudinal measurements are needed for a better understanding of this relation. In a recent study with such measurements on viral loads during disease course, only a severity score at admission was performed and unfortunately not longitudinal ${ }^{79}$.

Viral load analysis may also be a useful tool to study viral-viral and viral-bacterial interactions. For example, in children with RSV-RV multiple infections, we found a more severe disease course in children with a low viral load of RV (see subheading 'Multiple viral infections / viral-viral interactions' above). Furthermore, the viral load in single infections with RV, HCoV and PIV was significantly higher than for the same viruses in multiple infections, suggesting that these viruses are bystanders in mixed infections. These observations need to be confirmed in future studies with larger cohorts. 


\section{SUMMARIZING CONCLUSIONS}

In this thesis we try to re-define the position of RT-PCR for children with ARI in general hospital settings. We propose that it is not necessary for patient management to test for all known viruses. However, abandoning testing fully may lead to a lack of epidemiological data and hygiene control.

We advocate to use RT-PCR assays for RSV, FLU and Bordetella species in general paediatric hospital settings. Although the paediatricians in our study did not change their patient management after rapid reporting of RT-PCR results (chapter $\mathbf{2}$ ), it is well known that bacterial co-infection in laboratory confirmed RSV bronchiolitis is very limited in these settings ${ }^{41,42}$. Paediatricians should be aware of this and stop antibiotics in case of clinical diagnosis of bronchiolitis that is as well confirmed by a laboratory test. New vaccines and antiviral drugs for RSV will soon be available. This underscores the need for a laboratory confirmed diagnosis. In our opinion, FLU should be part of RT-PCR panels for children with ARI as early treatment of influenza with oseltamivir has shown to reduce disease severity ${ }^{80}$. Another argument to test for FLU is the increased risk of bacterial co-infection ${ }^{81}$. Early treatment is also important to prevent severe pertussis in individual patients and to prevent transmission of infection to (yet) unprotected individuals. As is shown in this thesis, pertussis cases are easily missed (chapter $\mathbf{5}$ ). We therefore advocate adding pertussis in a RT-PCR panel when it is considered. Especially in very young children, who are not or partially vaccinated, the paediatrician has to consider pertussis. When multiplex RT-PCR assays are implemented for clinical use, pertussis should be added. Finally, these three pathogens all are highly contagious and outbreaks on patient wards need to be prevented. Further research to management of outbreak prevention and the role of RT-PCR or other quick and reliable viral diagnostics is needed.

One of the studies was about the occurrence of apnoeas, a serious complication of young children with ARI (chapter 4). We showed that apnoeas occurred irrespective of the causative micro-organism, so apnoeas are not solely associated with RSV. We therefore advocate not to test for RSV to assess the risk of apnoeas. Parental reported apnoeas are a better warning sign than a positive RSV test.

Another lesson we have learned from our study is how to interpret single test results and multiple viral test results within one NWS. We showed that children with different single virus RT-PCR results do significantly differ with regard to some clinical aspects, but a recognizable clinical pattern per virus group was lacking (chapter $\mathbf{3}$ ). Furthermore, single- and multiple viral ARI did not significantly differ with regard to clinical outcome and patient management.

We also investigated viral load as marker of disease severity and concluded that viral load is not helpful to assess disease severity in children with ARI, but it is potentially helpful in resolving research questions like the role of viral-viral and viralbacterial interactions (chapter 6). Our findings on these viral interactions need to be confirmed in studies with larger populations. In future, longitudinal measurements of 
viral load in time are needed for a better understanding of the relationship between viral load and disease severity.

\section{FUTURE PERSPECTIVES}

\section{New markers for disease severity of viral ARI}

Detection of viruses and bacteria and measurement of viral load both focuses on the pathogen. It is likely that the host response to viruses itself may contribute to disease severity as well. Recently, a method to discriminate between mild and severe RSV infection based on differential host gene expression in nasopharyngeal aspirates of children with ARI was described ${ }^{82}$. New studies are demanded to implement these nasopharyngeal gene expression methods in clinical practice. Other markers at interest that correlate with disease severity of RSV infection are specific neutrophils and cytokine levels ${ }^{83}$. A combination of known and new biomarkers would be helpful too. It is known that CRP levels correlate with bacterial pneumonia ${ }^{84}$, but a correlation between CRP level and disease severity of viral disease has not been described in literature. CRP in combination with other inflammatory markers does seem to have a relationship with disease severity of viral ARI. Recently, a prediction rule combining CRP, serum amyloid A, pentraxin 3 and properdin was a better indicator of severe disease compared to the individual biomarkers and age ${ }^{85}$. However, these biomarkers are not introduced in daily clinical practice yet.

\section{New markers for differentiation between viral and bacterial ARI}

It is likely that reliable bacterial PCR assays or otherwise better confirmation of bacterial co-infection would also be helpful in clinical decision making regarding use of antibiotics. Probably a combination of known and new diagnostics to differentiate between viral and bacterial infection has a promising future. For example, the three host-protein based assay 'ImmunoXpert' combines CRP, tumour necrosis factor-related apoptosis-inducing ligand and interferon gamma induced protein-10 (OPPORTUNITY study) and this assay is recently validated for clinical use ${ }^{86}$. Another new approach is to identify personalized discriminators of bacterial and viral infection and inflammatory diseases. The PERFORM studies (Personalised Risk assessment in Febrile illness to Optimise Real-life Management across the European Union) are designed to use a combination of clinical phenotypic markers, host genetic markers, and biomarkers derived using transcriptomic, proteomic, and bioinformatic approaches. Inclusion of patients in these studies is already started over Europe.

\section{PCR to improve bacterial diagnostics}

Another new possible application of $P C R$ is to improve conventional bacterial diagnostics. Identification and antibiotic susceptibility testing using PCR was leading to fast results compared to standard of care testing in adult patients with bloodstream 
infections ${ }^{87}$. However, benefit on clinical outcomes was not shown, due to suboptimal implementation of the new test results.

\section{Point of care tests (POC)}

A disadvantage of RT-PCR is its relatively high turnaround time and its specific logistics that are needed to get results on time to the attending physician. In the future, novel point of care (POC) tests with the same of even better sensitivity and specificity than RT-PCR will reduce the time to process and report the results of samples. The use of 'aptamers', binding molecules that provide faster adaption to continuously evolving virus strains and higher discriminating capacity between specific virus serotypes will hopefully improve POC tests ${ }^{88}$. Another POC test is the Alere ${ }^{\mathrm{TM}} \mathrm{RSV}$ rapid POC test. It was found to have an overall sensitivity and specificity of 100\% (95Cl 93-100\%) and $97 \%(95 \mathrm{Cl} 89-100 \%)$ respectively compared to RT-PCR, results delivering within 13 minutes $^{89}$. Other new POC tests with multiplex assays are in development. A connection of POC tests to smartphones is another new field of interest, especially for non-hospital settings ${ }^{90}$. Another new easy and rapid detection device is based on antibody functionalized metallic nanoparticles, using UV-visible spectroscopy. This method is developed recently for detection of RSV ${ }^{91}$. Practical implications have to be investigated.

\section{New vaccines and antivirals}

Finally, we hope that this thesis will contribute to a better use of diagnostics for ARI in daily paediatric practice. We also hope that better diagnostics will contribute to a correct and efficient use of new vaccines and antivirals (chapter 1) as they become available in the near future, in order to minimize the burden of disease of paediatric respiratory tract infections. 


\section{REFERENCES}

1. Yorita KL, Holman RC, Sejvar JJ, Steiner CA and Schonberger LB. Infectious disease hospitalizations among infants in the United States. Pediatrics 2008;121(2):244-252.

2. Ralston SL, Lieberthal AS, Meissner HC, Alverson BK, Baley JE, Gadomski AM, Johnson DW, Light MJ, Maraqa NF, Mendonca EA, Phelan KJ, Zorc JJ, Stanko-Lopp D, Brown MA, Nathanson I, Rosenblum E, Sayles S and Hernandez-Cancio S; American Academy of Pediatrics. Clinical practice guideline: the diagnosis, management, and prevention of bronchiolitis. Pediatrics 2014;134(5):e1474-e1502.

3. Oosterheert JJ, van Loon AM, Schuurman R, Hoepelman Al, Hak E, Thijsen S, Nossent G, Schneider MM, Hustinx WM and Bonten MJ.. Impact of rapid detection of viral and atypical bacterial pathogens by real-time polymerase chain reaction for patients with lower respiratory tract infection. Clin Infect Dis 2005;41(10):1438-1444.

4. van de Pol AC, Wolfs TF, Tacke CE, Uiterwaal CS, Forster J, van Loon AM, Kimpen JL, Rossen JW and Jansen NJ. Impact of PCR for respiratory viruses on antibiotic use: theory and practice. Pediatr Pulmonol 2011;46(5):428-434.

5. Doan Q, Enarson P, Kissoon N, Klassen TP and Johnson DW. Rapid viral diagnosis for acute febrile respiratory illness in children in the Emergency Department. Cochrane Database Syst Rev 2012;5:CD006452.

6. Stollar F, Alcoba G, Gervaix A and Argiroffo CB. Virologic testing in bronchiolitis: does it change management decisions and predict outcomes? Eur J Pediatr 2014;173(11):1429-35

7. Huijskens EG, Biesmans RC, Buiting AG, Obihara CC and Rossen JW. Diagnostic value of respiratory virus detection in symptomatic children using real-time PCR. Virol J 2012;9:276.

8. Garcia-Garcia ML, Calvo C, Pozo F, Villadangos PA, Perez-Brena P and Casas I. Spectrum of respiratory viruses in children with community-acquired pneumonia. Pediatr Infect Dis J 2012;31(8):808-813.

9. Levin D, Tribuzio M, Green-Wrzesinki T, Ames B, Radwan S, Jarvis JD, Vaccaro T and Modlin JF. Empiric antibiotics are justified for infants with respiratory syncytial virus lower respiratory tract infection presenting with respiratory failure: a prospective study and evidence review. Pediatr Crit Care Med 2010;11(3):390-395.

10. Vallieres $E$ and Renaud C. Clinical and economical impact of multiplex respiratory virus assays. Diagn Microbiol Infect Dis 2013;76(3):255-261.

11. Bekhof J, Bakker J, Reimink R, Wessels M, Langenhorst V, Brand PL and Ruijs GJ. Co-infections in children hospitalised for bronchiolitis: role of roomsharing. J Clin Med Res 2013;5(6): 426-431.

12. Bont LJ. Nosocomial RSV infection control and outbreak management. Paediatr Respir Rev 2009;10 Suppl 1:16-17.

13. Mills JM, Harper J, Broomfield D and Templeton KE. Rapid testing for respiratory syncytial virus in a paediatric emergency department: benefits for infection control and bed management. J Hosp Infect 2011;77(3):248-251.

14. Drosten C, Gunther S, Preiser W, van der Werf S, Brodt HR, Becker S, Rabenau H, Panning $M$, Kolesnikova L, Fouchier RAM, Berger A, Burguière AM, Cinatl J, Eickmann M, Escriou N, Grywna K, Kramme S, Manuguerra JC, Müller S, Rickerts V, Stürmer M, Vieth S, Klenk HD, Osterhaus ADME, Schmitz H and Doerr HW. Identification of a novel coronavirus in patients with severe acute respiratory syndrome. N Engl J Med 2003;348(20):1967-1976.

15. Ksiazek TG, Erdman D, Goldsmith CS, Zaki SR, Peret T, Emery S, Tong S, Urbani C, Comer JA, Lim W, Rollin PE, Dowell SF, Ling AE, Humphrey CD, Shieh WJ, Guarner J, Paddock CD, Rota P, Fields B, DeRisi J, Yang JY, Cox N, Hughes JM, LeDuc JW, Bellini WJ and Anderson 
LJ; SARS Working Group. et al. A novel coronavirus associated with severe acute respiratory syndrome. N Engl J Med 2003;348(20):1953-1966.

16. Lai MM. SARS virus: the beginning of the unraveling of a new coronavirus. J Biomed Sci 2003;10(6 Pt 2):664-675.

17. Peiris JS, Lai ST, Poon LL, Guan Y, Yam LY, Lim W, Nicholls J, Yee WK, Yan WW, Cheung MT, Cheng VC, Chan KH, Tsang DN, Yung RW, Ng TK and Yuen KY; SARS study group. Coronavirus as a possible cause of severe acute respiratory syndrome. Lancet 2003;361(9366): 1319-1325.

18. Zaki AM, van BS, Bestebroer TM, Osterhaus ADME, Fouchier RAM. Isolation of a novel coronavirus from a man with pneumonia in Saudi Arabia. N Engl J Med 2012;367(19): 1814-1820.

19. Gao R, Cao B, Hu Y, Feng Z, Wang D, Hu W, Chen J, Jie Z, Qiu H, Xu K, Xu X, Lu H, Zhu W, Gao Z, Xiang N, Shen Y, He Z, Gu Y, Zhang Z, Yang Y, Zhao X, Zhou L, Li X, Zou S, Zhang Y, Li $X$, Yang L, Guo J, Dong J, Li Q, Dong L, Zhu Y, Bai T, Wang S, Hao P, Yang W, Zhang Y, Han J, Yu H, Li D, Gao GF, Wu G, Wang Y, Yuan Z and Shu Y. Human Infection with a Novel AvianOrigin Influenza A (H7N9) Virus. N Engl J Med 2013;368(20):1888-97

20. Tregoning JS and Schwarze J. Respiratory viral infections in infants: causes, clinical symptoms, virology, and immunology. Clin Microbiol Rev 2010;23(1):74-98.

21. Jartti T, Soderlund-Venermo M, Hedman K, Ruuskanen $O$ and Makela MJ. New molecular virus detection methods and their clinical value in lower respiratory tract infections in children. Paediatr Respir Rev 2013;14(1):38-45.

22. Brand HK, de Groot R, Galama JM, Brouwer ML, Teuwen K, Hermans PW, Melchers WJ and Warris $A$. et al. Infection with multiple viruses is not associated with increased disease severity in children with bronchiolitis. Pediatr Pulmonol 2012;47(4):393-400.

23. Cebey-Lopez M, Herberg J, Pardo-Seco J, Gómez-Carballa A, Martinón-Torres N, Salas A, Martinón-Sánchez JM, Justicia A, Rivero-Calle I, Sumner E, Fink C and Martinón-Torres F; GENDRES network. et al. Does Viral Co-Infection Influence the Severity of Acute Respiratory Infection in Children? PLoS One 2016;11(4):e0152481.

24. Martinez P, Cordero J, Valverde C, Unanue N, Dalmazzo R, Piemonte P, Vergara I and Torres JP. Viral respiratory co-infections in pediatric patients admitted for acute respiratory infection and their impact on clinical severity. Rev Chilena Infectol 2012;29(2):169-174.

25. Ricart S, Marcos MA, Sarda M, Anton A, Muñoz-Almagro C, Pumarola T, Pons M and Garcia-Garcia JJ. Clinical risk factors are more relevant than respiratory viruses in predicting bronchiolitis severity. Pediatr Pulmonol 2012;48(5):456-63

26. Versteegh FGA, Weverling GJ, Peeters MF, Wilbrink B, Veenstra-van Schie MT, van LeeuwenGerritsen JM, Mooi-Kokenberg EA, Schellekens JF and Roord JJ. Community-acquired pathogens associated with prolonged coughing in children: a prospective cohort study. Clin Microbiol Infect 2005;11(10):801-807.

27. Calvo C, Garcia-Garcia ML, Blanco C, Vázquez MC, Frías ME, Pérez-Breña P and Casas I. Multiple simultaneous viral infections in infants with acute respiratory tract infections in Spain. J Clin Virol 2008;42(3):268-272.

28. Semple MG, Cowell A, Dove W, Greensill J, McNamara PS, Halfhide C, Shears P, Smyth RL and Hart CA. Dual infection of infants by human metapneumovirus and human respiratory syncytial virus is strongly associated with severe bronchiolitis. J Infect Dis 2005;191(3): 382-386.

29. Harada Y, Kinoshita F, Yoshida LM, Minh le N, Suzuki M, Morimoto K, Toku Y, Tomimasu K, Moriuchi $\mathrm{H}$ and Ariyoshi K. Does respiratory virus coinfection increases the clinical severity of 
acute respiratory infection among children infected with respiratory syncytial virus? Pediatr Infect Dis J 2013;32(5):441-445.

30. Canducci F, Debiaggi M, Sampaolo M, Marinozzi MC, Berrè S, Terulla C, Gargantini G, Cambieri P, Romero E and Clementi M. Two-year prospective study of single infections and co-infections by respiratory syncytial virus and viruses identified recently in infants with acute respiratory disease. J Med Virol 2008;80(4):716-723.

31. Chorazy ML, Lebeck MG, MCCarthy TA, Richter SS, Torner JC and Gray GC. Polymicrobial acute respiratory infections in a hospital-based pediatric population. Pediatr Infect Dis J 2013;32(5):460-466.

32. Martin ET, Kuypers J, Wald A and Englund JA. Multiple versus single virus respiratory infections: viral load and clinical disease severity in hospitalized children. Influenza Other Respi Viruses 2012;6(1):71-77.

33. Goka EA, Vallely PJ, Mutton KJ and Klapper PE. Single and multiple respiratory virus infections and severity of respiratory disease: a systematic review. Paediatr Respir Rev 2014;15(4): 363-370.

34. Walzl G, Tafuro S, Moss P, Openshaw PJ and Hussell T. Influenza virus lung infection protects from respiratory syncytial virus-induced immunopathology. J Exp Med 2000;192(9): 1317-1326.

35. Wang $Y$, Zhang $Y$, Kong $W H$, Zhu HH, Lin XM, Yu B, Hu Q, Miao XP, Guo DY and Peng JS. Epidemiological characteristics of influenza virus and respiratory syncytial virus among children in Wuhan area from 2008 to 2012. Chinese, English abstract; Zhonghua Yu Fang Yi Xue Za Zhi 2013;47(5):415-419.

36. Meskill SD, Revell PA, Chandramohan L and Cruz AT. Prevalence of co-infection between respiratory syncytial virus and influenza in children. Am J Emerg Med 2017;35(3):495-498.

37. Casalegno JS, Ottmann M, Duchamp MB, Escuret V, Billaud G, Frobert E, Morfin F and Lina B. Rhinoviruses delayed the circulation of the pandemic influenza A (H1N1) 2009 virus in France. Clin Microbiol Infect 2010;16(4):326-329.

38. Pinky $L$ and Dobrovolny HM. Coinfections of the Respiratory Tract: Viral Competition for Resources. PLoS One 2016;11(5):e0155589.

39. Cebey-Lopez M, Pardo-Seco J, Gomez-Carballa A, Martinón-Torres N, Rivero-Calle I, Justicia A, Redondo L, Martinón-Sánchez JM, Martínez-Padilla Mdel C, Giménez-Sánchez F, Salas A and Martinón-Torres F; GENDRES Network. Bacteremia in Children Hospitalized with Respiratory Syncytial Virus Infection. PLoS One 2016;11(2):e0146599.

40. Thorburn K, Harigopal S, Reddy V, Taylor N and van Saene HK. High incidence of pulmonary bacterial co-infection in children with severe respiratory syncytial virus (RSV) bronchiolitis. Thorax 2006;61(7):611-615.

41. Ralston $S$, Hill $\vee$ and Waters $A$. Occult serious bacterial infection in infants younger than 60 to 90 days with bronchiolitis: a systematic review. Arch Pediatr Adolesc Med 2011;165(10): 951-956.

42. Farley R, Spurling GK, Eriksson L and Del Mar CB. Antibiotics for bronchiolitis in children under two years of age. Cochrane Database Syst Rev 2014;(10):CD005189.

43. Faber TE, Schuurs TA, Veeger NJ, Hennus MP and Bont LJ. Dynamics of nasopharyngeal pneumococcal carriage during the course of viral bronchiolitis. Pediatr Pulmonol 2016;51(8):863-867.

44. Vissers M, Ahout IM, van den Kieboom CH, van der Gaast-de Jongh CE, Groh L, Cremers AJ, de Groot R, de Jonge MI and Ferwerda G. High pneumococcal density correlates with more 
mucosal inflammation and reduced respiratory syncytial virus disease severity in infants. BMC Infect Dis 2016;16:129.

45. de Steenhuijsen Piters WA, Heinonen S, Hasrat R, Bunsow E, Smith B, Suarez-Arrabal MC, Chaussabel D, Cohen DM, Sanders EA, Ramilo O, Bogaert D and Mejias A. Nasopharyngeal Microbiota, Host Transcriptome, and Disease Severity in Children with Respiratory Syncytial Virus Infection. Am J Respir Crit Care Med 2016;194(9):1104-1115.

46. Rosas-Salazar C, Shilts MH, Tovchigrechko A, Schobel S, Chappell JD, Larkin EK, Shankar J, Yooseph S, Nelson KE, Halpin RA, Moore ML, Anderson LJ, Peebles RS Jr, Das SR and Hartert TV. Differences in the Nasopharyngeal Microbiome During Acute Respiratory Tract Infection With Human Rhinovirus and Respiratory Syncytial Virus in Infancy. J Infect Dis 2016;214(12):1924-1928.

47. Rothberg MB and Haessler SD. Complications of seasonal and pandemic influenza. Crit Care Med 2010;38(4 Suppl):e91-e97.

48. Freymuth F, Vabret A, Cuvillon-Nimal D, Simon S, Dina J, Legrand L, Gouarin S, Petitjean J, Eckart P and Brouard J. Comparison of multiplex PCR assays and conventional techniques for the diagnostic of respiratory virus infections in children admitted to hospital with an acute respiratory illness. J Med Virol 2006;78(11):1498-1504.

49. Briese T, Kapoor A, Mishra N, Jain K, Kumar A, Jabado OJ and Lipkin WI. Virome Capture Sequencing Enables Sensitive Viral Diagnosis and Comprehensive Virome Analysis. MBio 2015;6(5):e01491-15.

50. Anas N, Boettrich C, Hall CB and Brooks JG. The association of apnea and respiratory syncytial virus infection in infants. J Pediatr 1982;101(1):65-68.

51. Bruhn FW, Mokrohisky ST and McIntosh K. Apnea associated with respiratory syncytial virus infection in young infants. J Pediatr 1977;90(3):382-386.

52. Kneyber MC, Brandenburg AH, de Groot R, Joosten KF, Rothbarth PH, Ott A and Moll HA. Risk factors for respiratory syncytial virus associated apnoea. Eur J Pediatr 1998;157(4):331335.

53. Simoes EA. Respiratory syncytial virus infection. Lancet 1999;354(9181):847-852.

54. Wang EE, Law BJ and Stephens D. Pediatric Investigators Collaborative Network on Infections in Canada (PICNIC) prospective study of risk factors and outcomes in patients hospitalized with respiratory syncytial viral lower respiratory tract infection. J Pediatr 1995;126(2):212219.

55. Willwerth BM, Harper MB and Greenes DS. Identifying hospitalized infants who have bronchiolitis and are at high risk for apnea. Ann Emerg Med 2006;48(4):441-447.

56. Alansari K, Toaimah FH, Khalafalla H, El Tatawy LA, Davidson BL and Ahmed W. Caffeine for the Treatment of Apnea in Bronchiolitis: A Randomized Trial. J Pediatr 2016;177:204-211.

57. Maheux A, Pladys P and Laviolle B. Caffeine for apnea in bronchiolitis. J Pediatr 2017;182:405

58. Marchello C, Dale AP, Thai TN, Han DS and Ebell MH. Prevalence of Atypical Pathogens in Patients With Cough and Community-Acquired Pneumonia: A Meta-Analysis. Ann Fam Med 2016;14(6):552-566.

59. Tiwari T, Murphy TV and Moran J. Recommended antimicrobial agents for the treatment and postexposure prophylaxis of pertussis: 2005 CDC Guidelines. MMWR Recomm Rep 2005;54(RR-14):1-16.

60. Cherry JD, Tan T, Wirsing von Konig CH, Forsyth KD, Thisyakorn U, Greenberg D, Johnson $D$, Marchant $C$ and Plotkin S. Clinical definitions of pertussis: Summary of a Global Pertussis Initiative roundtable meeting, February 2011. Clin Infect Dis 2012;54(12):1756-1764. 
61. MartiniH, Detemmerman L, Soetens O, YusufE and Pierard D. Improving specificity of Bordetella pertussis detection using a four target real-time PCR. PLoS One 2017;12(4):e0175587.

62. Pittet LF, Emonet S, Francois P, Bonetti EJ, Schrenzel J, Hug M, Altwegg M, Siegrist CA and Posfay-Barbe KM. Diagnosis of whooping cough in Switzerland: differentiating Bordetella pertussis from Bordetella holmesii by polymerase chain reaction. PLoS One 2014;9(2):e88936.

63. Deng Y, Gu X, Zhao X, Luo J, Luo Z, Wang L, Fu Z, Yang X and Liu E. High viral load of human bocavirus correlates with duration of wheezing in children with severe lower respiratory tract infection. PLoS One 2012;7(3):e34353.

64. DeVincenzo JP, Wilkinson T, Vaishnaw A, Cehelsky J, Meyers R, Nochur S, Harrison L, Meeking P, Mann A, Moane E, Oxford J, Pareek R, Moore R, Walsh E, Studholme R, Dorsett P, Alvarez $R$ and Lambkin-Williams R. Viral load drives disease in humans experimentally infected with respiratory syncytial virus. Am J Respir Crit Care Med 2010;182(10):1305-1314.

65. Fodha I, Vabret A, Ghedira L, Seboui H, Chouchane S, Dewar J, Gueddiche N, Trabelsi A, Boujaafar N and Freymuth F. Respiratory syncytial virus infections in hospitalized infants: association between viral load, virus subgroup, and disease severity. J Med Virol 2007;79(12):1951-1958.

66. Fuller JA, Njenga MK, Bigogo G, Aura B, Ope MO, Nderitu L, Wakhule L, Erdman DD, Breiman RF and Feikin DR. Association of the CT values of real-time PCR of viral upper respiratory tract infection with clinical severity, Kenya. J Med Virol 2013;85(5):924-932.

67. Hasegawa K, Jartti T, Mansbach JM, Laham FR, Jewell AM, Espinola JA, Piedra PA and Camargo CA Jr. Respiratory syncytial virus genomic load and disease severity among children hospitalized with bronchiolitis: multicenter cohort studies in the United States and Finland. J Infect Dis 2015;211(10):1550-1559.

68. Houben ML, Coenjaerts FE, Rossen JW, Belderbos ME, Hofland RW, Kimpen JL and Bont LJ. Disease severity and viral load are correlated in infants with primary respiratory syncytial virus infection in the community. J Med Virol 2010;82(7):1266-1271.

69. Scagnolari C, Midulla F, Selvaggi C, Monteleone K, Bonci E, Papoff P, Cangiano G, Di Marco P, Moretti C, Pierangeli A and Antonelli G. Evaluation of viral load in infants hospitalized with bronchiolitis caused by respiratory syncytial virus. Med Microbiol Immunol 2012;201(3): 311-317.

70. Takeyama A, Hashimoto K, Sato M, Sato T, Kanno S, Takano K, Ito M, Katayose M, Nishimura $\mathrm{H}$, Kawasaki $\mathrm{Y}$ and Hosoya M. Rhinovirus load and disease severity in children with lower respiratory tract infections. J Med Virol 2012;84(7):1135-1142.

71. Utokaparch S, Marchant D, Gosselink JV, McDonough JE, Thomas EE, Hogg JC and Hegele $R G$. The relationship between respiratory viral loads and diagnosis in children presenting to a pediatric hospital emergency department. Pediatr Infect Dis J 2011;30(2):e18-e23.

72. Zhao B, Yu X, Wang C, Teng Z, Wang C, Shen J, Gao Y, Zhu Z, Wang J, Yuan Z, Wu F, Zhang X and Ghildyal R. High human bocavirus viral load is associated with disease severity in children under five years of age. PLoS One 2013;8(4):e62318.

73. Franz A, Adams O, Willems R, Bonzel L, Neuhausen N, Schweizer-Krantz S, Ruggeberg JU, Willers R, Henrich B, Schroten $\mathrm{H}$ and Tenenbaum T. Correlation of viral load of respiratory pathogens and co-infections with disease severity in children hospitalized for lower respiratory tract infection. J Clin Virol 2010;48(4):239-245.

74. Jansen RR, Schinkel J, Dek I, Koekkoek SM, Visser CE, de Jong MD, Molenkamp R and Pajkrt D. Quantitation of respiratory viruses in relation to clinical course in children with acute respiratory tract infections. Pediatr Infect Dis J 2010;29(1):82-84. 
75. Moesker FM, van Kampen JJ, van Rossum AMC, de Hoog M, Koopmans MP, Osterhaus ADME, Fraaij PLA. Viruses as Sole Causative Agents of Severe Acute Respiratory Tract Infections in Children. PLoS One 2016;11(3):e0150776.

76. Souza AP, Leitao LA, Luisi F, Souza RG, Coutinho SE, Silva JR, Mattiello R, Pitrez PM, Stein RT and Pinto LA. Lack of association between viral load and severity of acute bronchiolitis in infants. J Bras Pneumol 2016;42(4):261-265.

77. Van Leeuwen JC, Goossens LK, Hendrix RM, Van Der Palen J, Lusthusz A and Thio BJ. Equal virulence of rhinovirus and respiratory syncytial virus in infants hospitalized for lower respiratory tract infection. Pediatr Infect Dis J 2012;31(1):84-86.

78. Wright PF, Gruber WC, Peters M, Reed G, Zhu Y, Robinson F, Coleman-Dockery $S$ and Graham BS. Illness severity, viral shedding, and antibody responses in infants hospitalized with bronchiolitis caused by respiratory syncytial virus. J Infect Dis 2002;185(8):1011-1018.

79. Takeyama A, Hashimoto K, Sato M, Kawashima R, Kawasaki $Y$ and Hosoya M. Respiratory syncytial virus shedding by children hospitalized with lower respiratory tract infection. J Med Virol 2016;88(6):938-946.

80. Santesso N, Hsu J, Mustafa R, Brozek J, Chen YL, Hopkins JP, Cheung A, Hovhannisyan G, Ivanova L, Flottorp SA, Saeterdal I, Wong AD, Tian J, Uyeki TM, AkI EA, Alonso-Coello P, Smaill $F$ and Schünemann HJ. Antivirals for influenza: a summary of a systematic review and meta-analysis of observational studies. Influenza Other Respir Viruses 2013;7 Suppl 2: 76-81.

81. Rothberg MB, Haessler SD and Brown RB. Complications of viral influenza. Am J Med 2008;121(4):258-264.

82. van den Kieboom CH, Ahout IM, Zomer A, Brand KH, de Groot R, Ferwerda G and de Jonge MI. Nasopharyngeal gene expression, a novel approach to study the course of respiratory syncytial virus infection. Eur Respir J 2015;45(3):718-725.

83. Brown PM, Schneeberger DL and Piedimonte G. Biomarkers of respiratory syncytial virus (RSV) infection: specific neutrophil and cytokine levels provide increased accuracy in predicting disease severity. Paediatr Respir Rev 2015;16(4):232-240.

84. Flood RG, Badik J and Aronoff SC. The utility of serum C-reactive protein in differentiating bacterial from nonbacterial pneumonia in children: a meta-analysis of 1230 children. Pediatr Infect Dis J 2008;27(2):95-99.

85. Ahout IML, Brand HK, Zomer A, van den Hurk WH, Schilders G, Brouwer ML, Neeleman C, de Groot R and Ferwerda G. Assessing severity of disease in children with respiratory viral infections. Thesis Radboud university medical center of the Radboud University Nijmegen, the Netherlands: 2017.

86. van Houten CB, de Groot JAH, Klein A, Srugo I, Chistyakov I, de Waal W, Meijssen CB, Avis W, Wolfs TFW, Shachor-Meyouhas Y, Stein M, Sanders EAM and Bont LJ. A hostprotein based assay to differentiate between bacterial and viral infections in preschool children (OPPORTUNITY): a double-blind, multicentre, validation study. Lancet Infect Dis 2017;17(4):431-440.

87. Beuving J, Wolffs PF, Hansen WL, Stobberingh EE, Bruggeman CA, Kessels A and Verbon A. Impact of same-day antibiotic susceptibility testing on time to appropriate antibiotic treatment of patients with bacteraemia: a randomised controlled trial. Eur J Clin Microbiol Infect Dis 2015;34(4):831-838.

88. van den Kieboom CH, van der Beek SL, Mészaros T, Gyurcsayi RE, Ferwerda G and de Jonge MI. Aptasensors for viral diagnostics. Trends in Analytical Chemistry 2015;74:58-67. 
89. Peters RM, Schnee SV, Tabatabai J, Schnitzler P and Pfeil J. Evaluation of Alere i RSV for rapid detection of respiratory syncytial virus in children hospitalized with acute respiratory tract infection. J Clin Microbiol 2017;55(4):1032-1036

90. Radin JM, Topol EJ, Andersen KG and Steinhubl SR. A laboratory in your pocket. Lancet 2016;388(10054):1875.

91. Valdez J, Bawage S, Gomez I and Singh SR. Facile and rapid detection of respiratory syncytial virus using metallic nanoparticles. J Nanobiotechnology 2016;14:13. 


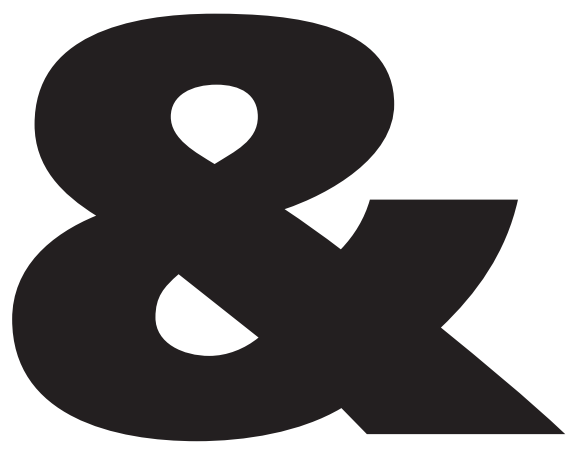


NEDERLANDSE SAMENVATTING

DANKWOORD CURRICULUM VITAE LIST OF PUBLICATIONS LIST OF ABBREVIATIONS 



\section{NEDERLANDSE SAMENVATTING}

Acute luchtweginfectie (acute respiratory infection, ARI) is wereldwijd gezien de meest voorkomende ziekte bij mensen. In de Westerse Wereld is het ook de belangrijkste oorzaak van ziekenhuisopname bij jonge kinderen'. Men zou verwachten dat microbiologische laboratoriumtechnieken kunnen helpen bij het stellen van een snelle en betrouwbare diagnose, het voorkómen van complicaties en het beperken van onnodig gebruik van antibiotica. Tot nu toe is het stellen van de diagnose van een ARI zoals bronchiolitis echter alleen mogelijk op basis van de anamnese van de ouders of verzorgers in combinatie met herhaalde beoordeling van de klinische toestand van het kind in de tijd².

Het inschatten van ziekte-ernst bij kinderen met een ARI op de spoedeisende hulp afdeling of op de kinderafdeling wordt sinds vele jaren ondersteund met transcutane zuurstofmeting en scorelijsten gebaseerd op parameters uit lichamelijk onderzoek. Daarnaast probeert men met conventionele virale diagnostiek de verantwoordelijke verwekker aan te tonen. In de laatste tien jaar is reverse transcriptase real-time polymerase chain reaction (RT-PCR) als diagnostische techniek geïntroduceerd in veel ziekenhuizen. De rol van deze moleculair diagnostische techniek in het verbeteren van de patiëntenzorg en het vergemakkelijken van klinische besluitvorming bij kinderen met ARI is echter niet bestudeerd voordat deze nieuwe techniek geïntroduceerd werd in de klinische praktijk. Er bestaat geen 'gouden standaard ' voor diagnostiek naar ARI.

Dit proefschrift beschrijft de rol van virale diagnostiek bij kinderen met ARI, met speciale aandacht voor de rol en positie van RT-PCR. Allereerst is een pilot study gedaan om de manier van klinische data verzamelen met gestandaardiseerde vragenlijsten en de logistiek van snelle rapportage van laboratoriumresultaten naar de kinderarts te optimaliseren.

Het primaire doel van de eerste studie van dit proefschrift was om de diagnostische opbrengst van RT-PCR voor kinderen met ARI in een algemeen ziekenhuis te bepalen en ook om het effect te bepalen van snelle rapportage van deze laboratoriumuitslagen aan de kinderarts op de patiëntenzorg. De uitkomstmaten waren hierbij de frequentie van ziekenhuisopnames, het aantal opnamedagen en het antibioticagebruik. Er werd hiertoe een gecontroleerde klinische studie uitgevoerd in twee Nederlandse ziekenhuizen gedurende twee winterseizoenen. Klinische data en neusspoelsels van 582 kinderen met luchtwegklachten werden achtereenvolgens verzameld. RT-PCR bepalingen op de neusspoelsels van beide ziekenhuizen werden in hetzelfde laboratorium uitgevoerd. De RT-PCR resultaten werden binnen 12-36 uur doorgegeven aan de kinderartsen in de interventiegroep en na vier weken in de controlegroep.

Dezelfde grote klinische database van deze RT-PCR bevestigde diagnoses werd gebruikt voor de secundaire doelen van de studie. Deze bestonden uit: a) het bepalen van het risico op ademstops bij jonge kinderen met ARI, b) het bepalen van de incidentie en relevantie van infecties met meer dan één micro-organisme, c) bestudering van 
de relatie tussen de hoeveelheid virus (viral load) en ziekte-ernst en d) het bepalen van de incidentie van gemiste kinkhoestinfecties.

\section{De belangrijkste bevindingen van dit proefschrift zijn:}

RT-PCR genereert een hoog aantal virale diagnoses, maar snelle rapportage hiervan aan de kinderarts leidt niet tot veranderingen in de behandeling van de patiënt.

Kinderen met verschillende enkelvoudig-virale RT-PCR uitslagen verschillen ten opzichte van elkaar met betrekking tot enkele klinische aspecten, maar een herkenbaar klinisch patroon per virusgroep ontbreekt.

Enkel- en meervoudig-virale ARI verschillen niet significant van elkaar met betrekking tot de klinische uitkomst en ook niet met betrekking tot het medisch beleid dat gevoerd wordt.

Ademstops bij kinderen met ARI treden onafhankelijk op van het geïsoleerde micro-organisme.

Ademstops, geobserveerd door ouders zijn een belangrijk alarmsignaal; als ouders of verzorgers thuis ademstops gezien hebben, dan worden deze ademstops ook tijdens de ziekenhuisopname waargenomen.

Kinkhoest bij kinderen lijkt soms erg op een virale ARI. Als RT-PCR diagnostiek naar Bordetella pertussis alleen gedaan wordt bij kinderen met een klinische verdenking op kinkhoest, dan wordt ongeveer één op de vijf werkelijke kinkhoestpatiënten gemist.

Paroxysmale hoest is niet uitsluitend geassocieerd met Bordetella pertussis, maar ook met ARI die veroorzaakt wordt door andere bacteriën en virussen. Afwezigheid van paroxysmale hoest sluit kinkhoest ook niet uit.

Hoewel er enkele statistisch significante relaties tussen viral load en klinische parameters gevonden werden bij kinderen met enkelvoudige- en bij kinderen met meervoudige virale ARI, is viral load niet geschikt om ziekte-ernst nauwkeurig in te schatten bij deze kinderen.

Bij kinderen met een Respiratoir Syncytieel Virus - Rhinovirus (RSV-RV) dubbelinfectie werd een sterke relatie gevonden tussen de cycle threshold (CT) waarde van RV en het aantal dagen ziekenhuisopname (length of hospital stay, LOS) en het aantal dagen zuurstoftherapie. Deze relatie werd niet gevonden bij enkelvoudige RV infecties, hetgeen suggereert dat een lage viral load van RV in RSV-RV dubbelinfecties gecorreleerd is met een ernstiger ziektebeloop. Dit suggereert een interactie tussen deze twee virussen bij kinderen met ARI.

De viral load in enkelvoudige RV infecties, Humaan Coronavirus (HCoV) infecties en Parainfluenza virus (PIV) infecties was significant hoger dan de viral load van dezelfde 
virussen in meervoudige infecties. Dit suggereert dat deze virussen onschuldige nevenbevindingen zouden kunnen zijn in deze meervoudige infecties.

In het algemeen kan viral load niet worden gebruikt om in meervoudige infecties te differentiëren tussen ziekmakend virus en een onschuldig virus.

\section{KLINISCH BELANG VAN RT-PCR BIJ KINDEREN MET ARI Het gebruik van RT-PCR in de algemene kindergeneeskunde}

In een prospectief gecontroleerd klinisch onderzoek hebben we laten zien dat RT-PCR tests een groot aantal virale diagnoses genereert, maar snelle communicatie van deze uitslagen naar de kinderarts leidt niet tot veranderingen in het klinisch beleid (hoofdstuk 2). Er is veel literatuur over de rol van virale diagnostiek. De mogelijkheid om door middel van deze diagnostiek ziekenhuis gerelateerde kosten zoals opnameduur te beperken en ook de mogelijkheid om onnodig antibioticagebruik hiermee te beperken is vaak het onderwerp van deze wetenschappelijke artikelen. In een studie met volwassen patiënten met lage luchtweginfecties leidde implementatie van RT-PCR wel tot een toename in het aantal virale diagnoses, maar niet tot een reductie van antibiotica of kosten ${ }^{3}$. In een kindergeneeskundige studie die in meerdere ziekenhuizen werd uitgevoerd, werden artsen gevraagd naar hun medisch beleid indien zij RT-PCR uitslagen zouden krijgen in fictieve ARI casuïstiek. De uitkomst was dat antibiotica gebruik zou dalen indien de artsen beschikten over deze RT-PCR uitslagen ${ }^{4}$. Na deze interviews met fictieve casuïstiek bleek echter dat dezelfde artsen in de werkelijke praktijk hun antibioticabeleid niet aanpasten na bekend worden van de RT-PCR uitslagen. In een Cochrane review met vier gerandomiseerd gecontroleerde studies werd de impact van snelle virale diagnostiek bij kinderen met ARI bestudeerd op een spoedeisende hulp afdeling. Hierin bleek snelle diagnostiek door immunofluorescentie of PCR niet te leiden tot veranderingen in antibiotica gebruik, lengte van spoedeisende hulp bezoeken, bloed- of urinetesten, maar wel werden er minder thorax foto's verricht ${ }^{5}$. De auteurs vonden routine virale tests op de spoedeisende hulp afdeling wel een veelbelovend middel om antibioticagebruik te beperken, maar vonden het bewijs hiervoor nog onvoldoende. Hiervoor zouden grotere studies nodig zijn die zich richten op het klinisch beleid voor de patiënt. In een recente retrospectieve studie werden de klinische verschillen tussen RSV en niet-RSV patiënten bestudeerd. Hierin bleek enzyme linked immunoassay en/of PCR niet te helpen in klinische beslissingen en bleken deze technieken ook niet geschikt om het ziektebeloop in te schatten op individueel niveau ${ }^{6}$. In een andere recente retrospectieve studie waarin 177 kinderen met ARI in een algemeen ziekenhuis waren opgenomen, bleek het antibiotisch regiem niet te veranderen na bekend worden van een viraal pathogeen. De auteurs stelden toch dat het routinematig testen van veel voorkomende respiratoire pathogenen kan leiden tot een beter begrip van hun rol 
in kinderen met luchtwegsymptomen ${ }^{7}$. In een prospectieve studie waarin kinderen zes jaar vervolgd werden met longontsteking (community acquired pneumonia, (AP), die opgezet was om de frequentie van respiratoire virussen te meten, werden antibiotica minder vaak voorgeschreven bij virus-positieve ten opzicht van virusnegatieve kinderen. Dit gold overigens alleen voor kinderen die ouder waren dan 18 maanden ${ }^{8}$.

Gebaseerd op de bovenstaande literatuur kan het routinematig testen op virussen door middel van RT-PCR voor kinderen in een algemeen ziekenhuis niet worden aanbevolen. In ons prospectief gecontroleerd klinisch onderzoek, hebben we de bevindingen van deze voorgaande studies bevestigd. Het is belangrijk om te weten dat de behandelend artsen in onze studies op geen enkele manier geïnstrueerd waren door de onderzoekers om hun klinisch beleid aan te passen na bekend worden van de RT-PCR resultaten. Zo waren de kinderartsen zich bewust van de lage incidentie van bacteriële co-infecties bij bewezen virale ARI, maar de beslissing om antibiotica wel of niet te stoppen na een positieve virale RT-PCR uitslag werd niet opgelegd door de onderzoekers. Onze bevindingen sluiten aan bij de richtlijnen van de American Association of Pediatrics (AAP), om geen routine virale testen te doen bij standaard ARI cases, tenzij de arts bereid is om het medisch beleid aan te passen op basis van de testresultaten ${ }^{2}$. Zo zouden antibiotica bij kinderen met bronchiolitis, die gestart zijn alvorens de testresultaten bekend zijn, gestopt moeten worden indien de testuitslag positief blijkt voor een virus.

\section{Het gebruik van RT-PCR bij geselecteerde patiëntengroepen}

De setting van onze studies was die van een algemeen ziekenhuis. Kinderen die opgenomen zijn op een kinder intensive care (PICU) zijn daarom geen onderdeel van onze studies. Deze kinderen met respiratoir falen, uitgelokt door een virale infectie en opgenomen op een PICU voor beademing, hebben vaak bijkomende bacteriële infecties ${ }^{9}$. Het gebruik van een uitgebreid RT-PCR panel voor respiratoire pathogenen lijkt hierbij gerechtvaardigd om een ziekteverwekker te kunnen aantonen. Kinderen met onderliggende immuunstoornissen kunnen gemakkelijk ernstige complicaties oplopen van "gewone" virale infecties. Zo vallen indicaties voor RT-PCR diagnostiek bij kinderen met hematologische maligniteiten, hematopoïetische stam cel transplantaties, orgaan transplantaties, prematuur geboren kinderen en kinderen met taaislijmziekte ook buiten de scope van dit proefschrift. Gegevens over deze patiënten groepen zijn beschreven door Vallieres en Renaud ${ }^{10}$.

\section{Het gebruik van RT-PCR bij infectiecontrole en preventie}

Infectiepreventie maatregelen zijn nodig om nosocomiale infecties (tijdens eenziekenhuisopnameopgelopen infecties) tevoorkomenenookomziekenhuispersoneel te beschermen. Isolatiemaatregelen en het verzorgen van kinderen met dezelfde ziekteverwekkers in één ruimte (cohorting) is een belangrijk middel om nosocomiale 
infecties te voorkomen. De epidemiologie van veel nosocomiale respiratoire infecties is niet goed bekend. Voor RSV lijkt de incidentie van nosocomiale verspreiding gering ${ }^{11}$. Hoewel informatie over het vóórkomen van ziekte-uitbraken gering is en niet goed gedocumenteerd, lijken normale preventiemaatregelen effectief ${ }^{12}$. Voor cohorting is aangetoond dat RSV sneltesten een kosteneffectieve en snelle manier zijn om optimaal gebruik te maken van het (beperkt aantal) ziekenhuisbedden ${ }^{13}$. Wij stellen echter dat snelle anigeentesten zoals direct immunofluorescent antibody tests niet geschikt zijn als basis waarop beslissingen genomen kunnen worden op het gebied van cohorting, omdat deze testen een hoog aantal fout negatieve uitslagen kunnen hebben. RT-PCR is veel sensitiever en specifieker, maar de turnaround time (tijd nodig om de test geheel uit te voeren) is niet snel genoeg om op tijd acties te kunnen ondernemen voor infectiecontrole bij opname. We vragen ons ook af of cohorting gebaseerd kan worden op RT-PCR uitslagen van een beperkt aantal virussen. Infecties met meerdere virussen tegelijk (meervoudige infecties) komen bij een flink aantal kinderen voor en het is nog niet duidelijk of deze kinderen andere niet-gedetecteerde virussen verspreiden tijdens cohorting. Het risico op besmetting van medepatiënten bij kinderen die samen een kamer delen is recent bestudeerd in een prospectief observationele cohortstudie van 48 kinderen met bronchiolitis. Het delen van een kamer tussen RSV-positieve en RSV-negatieve kinderen op de eerste opnamedag had geen invloed op het risico op co-infectie ${ }^{11}$.

\section{Het gebruik van RT-PCR bij epidemiologische surveillance}

Speciale indicaties voor RT-PCR als onderdeel van epidemiologische surveillance programma's vallen ook buiten de scope van onze studies. Voorbeelden zijn de wereldwijde zoektocht naar SARS en MERS coronavirusen, bekend als oorzaak van koorts en atypische longontsteking en hun fulminante beloop in een groot aantal aangedane patiënten ${ }^{14-18}$. Andere nationale en World Health Organisation (WHO)ondersteunde surveillance programma's zijn bijvoorbeeld de seizoens-influenza virussen. Op dit moment is 'vogelgriep' influenza A subtype H7N9 onder de speciale aandacht vanwege besmetting bij mensen en mogelijke overdracht van vogels naar mensen ${ }^{19}$.

\section{Conclusies}

RT-PCR heeft een zeer goede sensitiviteit en specificiteit vergeleken met conventionele virale diagnostiek. Gebaseerd op onze studies adviseren wij zeker niet om RT-PCR geheel te verbannen uit de dagelijkse kindergeneeskundige praktijk. We adviseren echter wel om de positie van RT-PCR te herevalueren. Wij stellen dat het niet klinisch relevant is om alle respiratoire virussen te testen bij alle patiënten. De vraag rijst dan welke virussen wel en welke niet opgenomen moeten worden in RT-PCR panels en welke patiënten getest moeten worden en welke niet. Om deze vragen te beantwoorden, hebben we verschillende studies verricht (hoofdstuk 3-6). 


\section{ENKELVOUDIGE EN MEERVOUDIGE RT-PCR TEST RESULTATEN}

Welke assays moeten er opgenomen worden in RT-PCR panels? Om deze vraag te beantwoorden moeten we eerst weten wat het betekent om een positief testresultaat te hebben voor een bepaald virus. Is het belangrijk om te weten of een infectie veroorzaakt is door virus $A$ of door virus B met betrekking tot ziekteernst en ziektebeloop? En hoe moeten we negatieve testresultaten of meervoudige testresultaten in één enkel neusspoelsel beoordelen? Om deze vragen te beantwoorden hebben we de relatie bestudeerd tussen klinische data en RT-PCR resultaten van kinderen met enkelvoudige en van kinderen met meervoudige virale ARI (hoofdstuk 3).

\section{Enkelvoudige infecties}

Het is algemeen bekend dat sommige virussen, zoals RSV een grotere ziektelast hebben dan andere virussen. En voor influenza zal niemand twijfelen aan de grote wereldwijde ziektelast. Literatuur over de klinische aspecten die samenhangen met deze virussen is erg uitgebreid, zoals beschreven is in hoofdstuk 1 van dit proefschrift. Het vergelijken van ziekte-ernst tussen deze individuele virussen is echter complex; studies op dit gebied verschillen met betrekking tot studieopzet, leeftijd bij inclusie, inclusiecriteria, de manier van data verzamelen, de gevoeligheid van de gebruikte assays in het laboratorium en het type virussen dat bestudeerd is ${ }^{20}$. Bovendien zijn meervoudige infecties niet altijd uitgesloten in studies die ziekte-ernst van individuele virussen beschrijven. Om deze verschillen tussen individuele virussen te bestuderen hebben we meervoudige infecties geëxcludeerd (hoofdstuk 3). Wij stelden vast dat patiëntgroepen met enkelvoudige virussen significant van elkaar verschilden met betrekking tot meerdere klinische aspecten, maar een herkenbaar klinisch patroon per virusgroep kon niet worden aangetoond. Ziekte(-ernst), klinisch beleid en klinisch beloop (outcome) waren niet geassocieerd met een specifiek virus. Lengte van ziekenhuisopname werd bepaald door de lengte van zuurstoftherapie of door de behoefte aan verneveltherapie met salbutamol en ipratropium. De vraag welke virussen aan een PCR panel moeten worden toegevoegd, kan niet worden beantwoord op basis van verschillen in ziekte-ernst van een infectie met deze individuele virussen.

\section{Meervoudige virale infectie en interacties tussen virussen}

Het percentage kinderen met meervoudige virale infecties die door RT-PCR gedetecteerd worden, is opgelopen tot $43 \%{ }^{21}$. In onze studies was de ziekte-ernst bij kinderen met meervoudige respiratoire infecties niet verhoogd ten opzichte van kinderen met enkelvoudig virale infecties. Deze bevinding komt overeen met de bevindingen van andere studies ${ }^{22-26}$. Andere onderzoekers toonden echter een grotere ziekte-ernst aan bij kinderen met meervoudig virale respiratoire infecties ${ }^{27-29}$. En weer anderen vonden juist een milder ziektebeloop bij kinderen met meervoudig virale infecties ${ }^{30-32}$. Hoewel meta-analyses theoretisch zouden kunnen helpen om meer definitieve conclusies te 
kunnen trekken, zijn deze moeilijk uit te voeren, omdat de studies te veel verschillen qua onderzoeksopzet en uitkomstparameters ${ }^{20}$. In een recent verschenen systematic review was de rol van meervoudige virale infectie als risicofactor voor ernstige virale ARI niet duidelijk ${ }^{33}$. De auteurs wijdden dit verschil in uitkomst niet alleen aan verschillen in seizoenen en studieperioden, maar ook aan de gebruikte statistische methoden: bias towards the null is mogelijk in studies waarin alleen ruwe data geanalyseerd worden. Toekomstige studies moeten daarom gestratificeerde analyses gebruiken en het effect bestuderen van bepaalde combinaties van virussen die samen voorkomen. Sommige onderzoekers suggereren inderdaad dat interacties tussen verschillende virussen bestaan: in een muismodel werd de groei van RSV geremd door competitieve infectie met $\mathrm{FLU}^{34}$. Epidemiologische data suggereren ook het bestaan van competitie tussen deze virussen; in perioden dat RSV veel voor kwam, kwam FLU minder voor en vice-versa ${ }^{35}$. Recentelijk werd aangetoond dat de incidentie van RSV-FLU meervoudige infectie minder was dan de verwachte incidentie, zelfs wanneer beide virussen tegelijkertijd circuleerden ${ }^{36}$. FLU kan ook een reactie aangaan met RV. Een Franse studie liet een onverwacht traag begin zien van de FLU A (H1N1) epidemie in 200937. De auteurs weten dit aan een intens circuleren van RV in die periode. Een andere onderzoeksgroep probeerde deze virale competities te verklaren met behulp van een wiskundig model: tijdens een meervoudig virale infectie kan het ene virus geblokkeerd worden door het andere virus door het eerste virus te zijn dat de beschikbare gastheercellen bezet, zonder dat immuunrespons reacties hierbij betrokken zijn ${ }^{38}$. In onze eigen studies vonden we geen verschillen in klinische symptomen en in klinisch beleid tussen de vijf meest voorkomende virale combinaties (RSV/HCoV, RSV/RV, RSV/HAdV, RSV/hMPV, RSV/PIV). Als we echter CT waarde van RT-PCR in onze analyses betrokkken, dan vonden we een sterke correlatie tussen de CT waarde van RV en LOS en lengte van zuurstoftherapie bij kinderen met RSV-RV meervoudige infecties (hoofdstuk 6). Deze correlatie werd niet gevonden bij RV enkelvoudige infecties, hetgeen suggereert dat een lage viral load van RV bij RSV-RV meervoudige infecties samenhangt met een ernstiger ziektebeloop. Deze bevinding steunt het idee dat interacties tussen virussen bestaan. Het mechanisme dat ziekteernst bepaalt in meervoudige infecties is nog niet goed bekend en hiervoor is meer onderzoek nodig.

\section{Virale - bacteriële co-infectie / interacties}

Het samen voorkomen van een virus en een bacterie als ziekteverwekker in één neusspoelsel wordt hier "co-infectie" genoemd. We hebben ons in de studies niet specifiek gericht op de aan- of afwezigheid van virale - bacteriële co-infecties en bacteriële kweken waren ook geen standaard procedure in het behandelingstraject van onze patiënten. Het risico op een bacteriële co-infectie bij kinderen met RSV infectie lijkt beperkt. Echter, in een studie met 66 opgenomen kinderen met RSV werd een bacteriemie gevonden in $10.6 \%{ }^{39}$. Bij die kinderen die een positief bacterieel 
testresultaat hadden, was er vooraf een verdenking op een bacterieel superinfectie en de ziekte-ernst was significant hoger dan bij de kinderen met negatieve bacteriële testresultaten. Bij patiënten die opgenomen werden op een PICU vanwege een ernstig beloop van een RSV infectie, was tot $40 \%$ geïnfecteerd met bacteriën in hun onderste luchtwegen ${ }^{40}$. Dit bewijst echter niet dat kinderen met bronchiolitis veroorzaakt door RSV een hogere gevoeligheid hebben op het krijgen van een bacteriële infectie. In een systematic review met jonge kinderen met bronchiolitis was de incidentie van bacteriemie of meningitis inderdaad extreem laag ${ }^{41}$. Een recente update van een Cochrane review van kinderen met bronchiolitis toonde ook een erg laag risico aan op bacteriële co-infectie en de conclusie was dat er geen bewijs was om het gebruik van antibiotica aan te bevelen bij deze kinderen. Toekomstig onderzoek naar het gebruik van antibiotica dient zich te richten op kleine subgroepen van patiënten, zoals patiënten met respiratoir falen die opgenomen zijn op een PICU, kinderen met een cyanotisch hartgebrek of kinderen met nosocomiaal verworven RSV ${ }^{42}$.

Er zijn aanwijzingen dat virussen en commensaal voorkomende bacteriën interacties met elkaar aangaan. Bij kinderen met klinisch vastgestelde bronchiolitis was virale infectie negatief geassocieerd met pneumokokken kolonisatie van de bovenste luchtwegen ${ }^{43}$. Er lijkt een complexe relatie te bestaan tussen nasofaryngeaal dragerschap van pneumokokken en ziektebeloop van kinderen met RSV bronchiolitis ${ }^{44}$. De interactie tussen RSV en microbiota in het neus-keelgebied kan de immuunrespons moduleren en kan mogelijk ook ziekte-ernst beïnvloeden bij kinderen met RSV45. Een andere studie liet verschillende microbiële profielen in het neus-keelgebied zien tussen kinderen met RSV- en kinderen met RV gerelateerde ARI ${ }^{46}$.

Bij patiënten met FLU werd een verhoogde gevoeligheid voor bacteriële infectie reeds vele jaren geleden aangetoond. Het optreden van secundaire bacteriële longontsteking was de doodsoorzaak van veel patiënten in de 1918-1919 influenza pandemie. Bij kinderen met FLU, moet men bedacht zijn op het ontstaan van ernstige secundaire bacteriële infectie, vooral met Staphylococcus aureus en Streptococcus pneumoniae ${ }^{47}$.

\section{Negatieve RT-PCR test resultaten}

RT-PCR assays hebben een hoge sensitiviteit en specificiteit ${ }^{48}$. In onze studie waren 476 van de 582 neusspoelsels (82\%) positief voor een of meerdere pathogenen. De resterende 106 neusspoelsels (18\%) hadden negatieve testresultaten. Bij deze kinderen was de ziekte-ernst (disease severity score, DSS), het aantal kinderen met koorts, LOS, het aantal dagen zuurstoftherapie en het aantal dagen antibiotische therapie significant lager vergeleken met patiënten met positieve testresultaten (hoofdstuk 3, Tabel 6). Alle kinderen die in onze studie geïncludeerd werden, presenteerden zich bij de kinderarts met luchtwegklachten. Van de 106 patiënten met negatieve RT-PCR testresultaten werden 23 patiënten gediagnosticeerd bij ontslag als "geen luchtweginfectie". De klinische diagnoses van deze kinderen waren breath 
holding spells $(n=1)$, ademhalingsproblemen meest waarschijnlijk veroorzaakt door gastro-oesofageale reflux $(n=8)$, parechovirus meningitis $(n=1)$, echovirusinfectie $(n=1)$, rotavirus infectie $(n=1)$, virale infectie/ geen specifieke diagnose $(n=11)$. Het aantal patiënten met een klinische diagnose ARI bij ontslag en een negatief RT-PCR resultaat kwam hiermee op $106-23=83$ (83 van de $582=14 \%$ ).

Er zijn verschillende gastheer-, virale- en laboratoriumfactoren die de CT waarde van RT-PCR kunnen beïnvloeden en dus mogelijk bijdragen aan negatieve testresultaten. Deze factoren zijn beschreven in hoofdstuk 6. Ondanks deze factoren kunnen we niet uitsluiten dat met nieuwe technieken zoals "next-generation" sequencing of "virome capture sequencing platform for vertebrate viruses" (VirCapSeq-VERT), beschreven in $2015^{49}$, sommige van onze negatief geteste neusspoelsels toch een positief resultaat zouden hebben laten zien. Helaas kunnen we de neusspoelsels hier niet meer op testen, omdat er geen materiaal over is.

Tenslotte moet gezegd worden dat men met behulp van RT-PCR alleen resultaten verkrijgt van virussen waarop getest is. Zo waren bijvoorbeeld Enterovirus D68 en de polyomavirusen WU en KI niet opgenomen in ons testpanel. Zoals in de introductie (hoofdstuk 1) beschreven, zijn de incidentiepatronen van deze virussen niet bekend. We kunnen dus niet uitsluiten dat sommige kinderen met negatieve RT-PCR testresultaten positief zouden zijn getest voor een van deze virussen. Het is ook mogelijk dat sommige kinderen met negatieve RT-PCR test resultaten geïnfecteerd waren met virussen die tot nu toe nog niet ontdekt zijn.

\section{ADEMSTOPS}

Het optreden van ademstops is een ernstige complicatie van ARI bij jonge kinderen. Bekende risicofactoren hiervoor zijn vroeggeboorte, een luchtweginfectie die snel na de geboorte optreedt, een voorgeschiedenis van ademstops of zuurstofgebrek en comorbiditeit van de luchtwegen ${ }^{50-55}$. Wij bestudeerden het effect van de individuele virussen op het optreden van ademstops (hoofdstuk 4). Ademstops traden onafhankelijk van de geïsoleerde micro-organismen op en wij adviseren om RSV tests niet te gebruiken om kinderen op te sporen die at risk zijn voor opname in het ziekenhuis ter observatie van mogelijk optredende ademstops. Onze studie ondersteunt het belang van navragen bij de ouders of verzorgers of zij ademstops gezien hebben: het voorspelt dat ademstops dan ook in het ziekenhuis geobjectiveerd worden.

Studies naar ademstops zijn vaak moeilijk te interpreteren, vooral omdat de definities van ademstops verschillen in de literatuur. Ook is de registratie van ademstops door continue monitoring van vitale parameters op een kinderafdeling van een algemeen ziekenhuis minder nauwkeurig dan in een PICU setting. Hetzelfde probleem geldt voor een recente studie die geen effect liet zien van een enkele dosis coffeïne om ademstops te voorkomen bij kinderen met ARI op een spoedeisende hulp afdeling in Qatar ${ }^{56}$ : 'thuis geobserveerde ademstops zijn subjectief en cardiorespiratoire 
problemen zijn niet geregistreerd met een monitor ${ }^{\prime 57}$. Veruit de meeste kinderen met ademstops bij ARI zijn echter niet opgenomen op PICU's, maar op kinderafdelingen van algemene ziekenhuizen. Toekomstig wetenschappelijk onderzoek moet rekening houden met de minder nauwkeurige registratie van ademstops in deze setting.

\section{KINKHOEST}

Zoals eerder gezegd verkrijgt men met RT-PCR alleen die resultaten van pathogenen waarop getest is. In hoofdstuk $\mathbf{5}$ hebben we het probleem beschreven van gemiste kinkhoestdiagnoses bij jonge kinderen met ARI. Het klinisch beeld van kinderen met kinkhoest varieert van de klassieke presentatie met paroxysmale hoest en een ernstig ziektebeloop tot alleen maar neusverkoudheid met een mild ziektebeloop dat niet te onderscheiden is van virale ARI. Wij lieten zien dat ongeveer één op de vijf gevallen van kinkhoest gemist wordt indien er alleen getest wordt op kinkhoest bij een klinische verdenking hierop. Hetzelfde probleem van gemiste kinkhoest gevallen is duidelijk in een recente meta-analyse die de prevalentie van atypische pathogenen bestudeert bij patiënten met hoest en longontsteking (CAP). De auteurs vonden een hoge prevalentie van Bordetella pertussis in studies waarin epidemiologische surveillance data beschikbaar waren en waarin alle kinderen getest werden op kinkhoest ${ }^{58}$. Voor de individuele patiënt kan een gemiste diagnose kinkhoest een probleem zijn omdat antibiotica in een vroeg stadium van de ziekte de duur van de symptomen kan verkorten ${ }^{59}$.

Naast het belang voor de individuele patiënt zijn gemiste kinkhoest diagnoses ook een bedreiging voor de populatie, omdat onbehandelde patiënten kinkhoest zullen verspreiden. Wij ondersteunen de aanbevelingen die reeds door de Global Pertussis Initiative Round Table Meeting ${ }^{60}$ zijn opgesteld, om de diagnose kinkhoest vaker in het laboratorium te bevestigen om zo besmetting in de populatie te beheersen. Men moet hierbij erop bedacht zijn dat naast Bordetella pertussis, andere Bordetella soorten ook met ARI geassocieerd zijn: Bordetella parapertussis, Bordetella holmesii en Bordetella bronchiseptica. De RT-PCR target IS481 maakt geen onderscheid tussen deze soorten. Omdat de rol van deze verschillende Bordetella soorten nog steeds onduidelijk is, is verder onderzoek nodig om te bepalen of soort-specifieke targets nodig zijn ${ }^{61,62}$.

Onderzoeken naar kosteneffectiviteit van meer frequente laboratorium diagnostiek ten opzichte van minder vaak gemiste kinkhoest diagnoses om zo besmetting in de bevolking te voorkomen zouden ook gedaan moeten worden.

\section{VIRAL LOAD}

Een andere onderzoeksvraag die wij hadden was om de relatie te onderzoeken tussen de hoeveelheid virus die aangetoond wordt in een neusspoelsel en ziekteernst bij kinderen met ARI. Sommige onderzoekers suggereren een positieve relatie hiertussen ${ }^{63-72}$, terwijl anderen die relatie niet zien ${ }^{73-78}$. Wij probeerden de vraag te 
beantwoorden of het aantal cycli dat de RT-PCR nodig heeft om een positief signaal te geven (cycle threshold value, CT waarde) bruikbaar is voor de kindergeneeskundige praktijk. We vonden inderdaad enkele relaties tussen CT waarden en klinische parameters bij patiënten met enkelvoudige en meervoudige virale ARI (hoofdstuk 6). De individuele verschillen in gastheer-, virus- en laboratoriumfactoren maken de interpretatie van deze statistisch significante verschillen echter gecompliceerd. Een correct gebruik van de statische methode zélf is ook een uitdaging op dit gebied.

In de kindergeneeskunde praktijk is virale diagnostiek vaak gebruikt als een enkelvoudige meting bij eerste presentatie van een kind op de spoedeisende hulpafdeling of polikliniek. Deze omstandigheden zijn echter niet optimaal om de relatie tussen viral load en ziekte-ernst te bestuderen, omdat viral load een dynamisch proces is. In de toekomst zijn daarom studies nodig met longitudinale metingen van viral load om deze relatie beter te begrijpen. In een recente studie met zulke longitudinale metingen van viral load tijdens het ziektebeloop, werd slechts een ziekte-ernst score verricht bij opname en helaas niet longitudinaal ${ }^{79}$.

Viral load analyse zou ook behulpzaam kunnen zijn bij het bestuderen van viraalvirale en viraal-bacteriële interacties. Bij kinderen met RSV-RV meervoudige infecties vonden wij bijvoorbeeld een ernstiger ziektebeloop bij kinderen met een lage viral load van RV (zie sub-hoofdstuk 'Meervoudige virale infectie en interacties tussen virussen' hierboven). Daarnaast was de viral load in enkelvoudige infecties met RV, $\mathrm{HCOV}$ en PIV significant hoger dan voor dezelfde virussen in meervoudige virale infecties. Dit suggereert dat deze virussen onschuldige nevenbevindingen zijn in deze meervoudige virale infecties. Deze observaties moeten bevestigd worden in onderzoeken met grotere patiënten aantallen.

\section{CONCLUSIES}

Dit proefschrift zet aan tot het herdefiniëren van de positie van RT-PCR voor kinderen met ARI in algemene ziekenhuis-settings. Wij stellen dat het niet nodig is voor het klinisch beleid om op alle bekende virussen te testen. Het volledig uitbannen van testen zou echter kunnen leiden tot onderbehandeling van infecties waarvoor een therapie bestaat die gericht is op het pathogeen, een gebrek aan epidemiologische data over (virus)infecties en een slechte infectie controle.

Wij pleiten om RT-PCR assays te gebruiken voor RSV, FLU en Bordetella pertussis in algemene ziekenhuis-settings. Hoewel de kinderartsen in onze studie hun beleid niet veranderden na snelle rapportage van de RT-PCR resultaten (hoofdstuk 2 ), is het algemeen bekend dat bacteriële co-infecties in laboratorium bevestigde RSV bronchiolitis erg weinig voorkomt in deze settings ${ }^{41,42}$. Kinderartsen zouden zich hier bewust van moeten zijn en zij zouden antibiotica moeten stoppen in het geval van een klinische diagnose van bronchiolitis, die bevestigd is door een laboratoriumtest. Nieuwe vaccinaties en antivirale middelen zullen spoedig beschikbaar komen. Dit 
onderstreept de behoefte aan een laboratorium bevestigde diagnose. Naar onze mening zou FLU ook deel moeten zijn van RT-PCR panels voor kinderen met ARI, omdat vroege behandeling van influenza met oseltamivir ziekte-ernst vermindert ${ }^{80}$. Een ander argument om FLU te testen, is het verhoogd risico op bacteriële co-infecties ${ }^{81}$. Vroege behandeling is ook belangrijk om ernstige kinkhoest bij individuele patiënten en transmissie van infectie naar (nog) niet beschermde personen te voorkomen. Zoals in dit proefschrift is beschreven worden kinkhoest gevallen makkelijk gemist (hoofdstuk 5). Wij pleiten er daarom voor om kinkhoest toe te voegen aan RT-PCR panels als het overwogen wordt. Vooral bij jonge kinderen, die slechts gedeeltelijk gevaccineerd zijn, moet de kinderarts denken aan kinkhoest. Als multiplex RT-PCR's gebruikt worden voor klinisch gebruik, dan dient kinkhoest hieraan toegevoegd te worden naar onze mening. Tenslotte zijn deze drie pathogenen alle erg besmettelijk en ziekte-uitbraken op patiëntenafdelingen dient uiteraard te allen tijde voorkomen te worden. Nader onderzoek naar het voorkomen van ziekte-uitbraken en de rol van RT-PCR of andere snelle en betrouwbare virale diagnostiek is nodig.

Het onderwerp van een van de studies was ademstops, een belangrijke complicatie van ARI bij jonge kinderen (hoofdstuk 4). Wij lieten zien dat ademstops voorkwamen onafhankelijk van het veroorzakend micro-organisme, dus ademstops zijn niet exclusief geassocieerd met RSV. Wij adviseren daarom om niet op RSV te testen, alleen om het risico op ademstops in te schatten. Door ouders gemelde ademstops zijn een meer betrouwbaar alarmteken dan een positieve RSV test.

Een andere les die we geleerd hebben van onze studies is hoe enkelvoudig virale testresultaten en meervoudig virale testresultaten te interpreteren binnen één enkel neusspoelsel. We lieten zien dat kinderen met verschillende enkelvoudig virale RT-PCR test resultaten significant van elkaar verschilden met betrekking tot sommige klinische aspecten, maar een herkenbaar klinisch patroon per virus groep ontbrak (hoofdstuk 3). Verder verschilden enkel- en meervoudig virale ARI niet significant met betrekking tot klinische beleid en ziektebeloop.

We bestudeerden ook viral load als marker voor ziekte-ernst en concludeerden dat viral load geen bijdrage had in het inschatten van ziekte-ernst bij kinderen met ARI. Wel kan viral load bijdragen aan het oplossen van onderzoeksvragen zoals de rol van viraal-virale en viraal-bacteriële interacties (hoofdstuk 6). Onze bevindingen over deze virale interacties dienen bevestigd te worden in studies met grotere populaties. In de toekomst zijn longitudinale metingen van viral load in de tijd nodig om de relatie tussen viral load en ziekte-ernst beter te begrijpen.

\section{TOEKOMSTPERSPECTIEVEN}

\section{Nieuwe markers voor ziekte-ernst van virale ARI}

Detectie van virussen en bacteriën en meting van viral load focussen beide op het pathogeen. Het is aannemelijk dat de gastheerrespons op virussen zelf ook aan 
de ziekte-ernst bijdraagt. Recent is een methode beschreven om onderscheid te kunnen maken tussen milde en ernstige RSV infectie, gebaseerd op verschillende gen-expressie in de gastheer in neus-keel spoelsels van kinderen met $A R{ }^{182}$. Nieuwe studies zijn nodig om deze genexpressie methoden te implementeren voor klinische toepassing. Andere markers die onderzocht worden op hun relatie met ziekte-ernst van RSV infectie zijn specifieke neutrofiele en cytokine spiegels ${ }^{83}$. Een combinatie van bekende en nieuwe markers zou ook behulpzaam zijn. Het is bekend dat de hoogte van het C-reactive protein (CRP) een relatie heeft met bacteriële longontsteking ${ }^{84}$, maar een relatie tussen CRP getal en ziekte-ernst van een virale infectie is niet beschreven. CRP in combinatie met andere inflammatoire markers lijkt wel een relatie te hebben met ziekte-ernst van virale ARI. Recent bleek een voorspellingsmodel van een combinatie van CRP, serum amyloid A, pentraxin 3 en properdine een betere indicator voor ziekte-ernst dan de individuele biomarkers en leeftijd ${ }^{85}$. Deze biomarkers zijn echter nog niet geïntroduceerd in de klinische praktijk.

\section{Nieuwe markers voor differentiatie tussen virale en bacteriële ARI}

Het is aannemelijk dat betrouwbare bacteriële PCR assays of anderszins een betere bevestiging van bacteriële co-infectie behulpzaam zou zijn bij klinische besluitvorming met betrekking tot antibiotica gebruik. Waarschijnlijk heeft een combinatie tussen bekende en nieuwe diagnostische methoden de toekomst. Als voorbeeld: de driegastheer-eiwit gebaseerde assay 'ImmunoXpert' combineert CRP, tumor necrosis factor-related apoptosis-inducing ligand en interferon gamma induced protein-10 (OPPORTUNITY study). Deze bepaling is recent gevalideerd voor gebruik in de klinische praktijk ${ }^{86}$. Een andere nieuwe benadering is het identificeren van gepersonaliseerde discriminatoren van bacteriële en virale infecties en inflammatoire ziektes. De PERFORM studies (Personalised Risk assessment in Febrile illness to Optimise Reallife Management across the European Union) testen hiervoor een combinatie van klinisch fenotypische markers, gastheer genetische markers en andere biomarkers op gen- en eiwitniveau. Inclusie van patiënten in deze studies is al gestart in Europa.

\section{PCR ter verbetering van bacteriële diagnostiek}

Een andere nieuwe mogelijke toepassing van PCR is om hiermee conventionele bacteriële diagnostiek te verbeteren. Identificatie en het testen van antibiotische gevoeligheid door middel van gebruik van PCR leidde tot snelle resultaten vergeleken met de gouden standaardtesten bij volwassen patiënten met bloedbaaninfecties ${ }^{87}$. Een voordeel voor het klinisch beloop van de patiënten werd echter niet gezien, als gevolg van suboptimale implementatie van de nieuwe test resultaten.

\section{Point of care tests (POC)}

Een nadeel van RT-PCR is de relatief hoge turnaround time en zijn specifieke logistiek die nodig is om resultaten op tijd bij de arts te krijgen. In de toekomst zullen nieuwe 
point of care testen (POC) met dezelfde, of zelfs betere sensitiviteit en specificiteit dan RT-PCR, de verwerkingstijd verminderen en ook de tijd die nodig is om resultaten te rapporteren. Het gebruik van 'aptameren' zullen hopelijk POC testen verbeteren ${ }^{88}$. Aptameren zijn bindingmoleculen die een snellere aanpassing aan de zich continu ontwikkelde virusstrengen hebben en een hoger discriminerend vermogen hebben voor verschillende specifieke virus serotypen. Een andere POC test is de Alere ${ }^{\mathrm{TM}}$ RSV rapid POC test. Deze test bleek een sensitiviteit en specificiteit van respectievelijk $100 \%(95 \mathrm{Cl} 93-100 \%)$ en $97 \%(95 \mathrm{Cl} 89-100 \%)$ te hebben, vergeleken met RT-PCR en resultaten te leveren binnen 13 minuten $^{89}$. Andere nieuwe POC testen met multiplex assays zijn in ontwikkeling. Een verbinding tussen POC testen en smartphones is een ander nieuw interessant ontwikkelingsgebied, voornamelijk voor settings buiten het ziekenhuis ${ }^{90}$. Een andere nieuwe makkelijke en snelle methode is gebaseerd op antilichaam 'functionalized' metalen nanopartikels, met gebruik van ultraviolet spectroscopie. Deze methode is recent ontwikkeld voor het aantonen van $\mathrm{RSV}^{91}$. De praktische gevolgen hiervan moeten nog worden onderzocht.

\section{Nieuwe vaccinaties en antivirale middelen}

Tenslotte hopen we dat dit proefschrift bijdraagt aan een beter gebruik van diagnostiek voor ARI in de dagelijkse kindergeneeskundige praktijk. De meest belangrijke bevindingen zijn benoemd aan het begin van dit hoofdstuk en in de stellingen van dit proefschrift. We hopen ook dat betere diagnostiek bij zal dragen aan een correct en efficiënt gebruik van nieuwe vaccinaties en antivirale middelen (hoofdstuk 1) zodra deze beschikbaar worden in de nabije toekomst, om zo de ziektelast van luchtweginfecties bij kinderen te verminderen.

De referenties staan bij hoofdstuk 7 . 


\section{DANKWOORD}

Gelukt! Het voelt geweldig om na een lange tijd dit proefschrift tot een goed einde te brengen. Bij het combineren van klinisch werk met wetenschappelijk onderzoek zonder een afgesproken harde deadline, blijkt het laatste zich in het meest listige kwadrant van timemanagement te bevinden: "wel belangrijk - niet urgent". De druk neemt automatisch toe naarmate de tijd vordert. Opmerkelijk ook, dat veel life-events zich lijken te concentreren in dezelfde periode die je uitkiest voor zo'n groot project. Net als nachtdiensten, waarvan je er soms in een maand veel meer hebt dan dat logisch zou zijn op basis van de gemiddelde dienstfrequentie per jaar. Nu het bijna klaar is, tijd voor een dankwoord, aan eenieder die bijdroeg aan dit proefschrift en deze leuke tijd!

Allereerst bedank ik de jonge kinderen en de ouders die meededen aan dit onderzoek. Jullie gaven belangeloos toestemming waarvoor ik jullie zeer dankbaar ben. Zonder jullie geen proefschrift.

Dr. N.G. Hartwig, beste Nico, vanaf de eerste ideeën voor dit proefschrift tot en met de laatste hoofdstukken, ben je een fantastische coach geweest. Ik dank je voor het vertrouwen en voor het vele werk dat je hebt gedaan. Met jou praten over kinderinfectieziekten is een genoegen vanwege je diepgaande kennis ervan en je uitmuntende manier om het op anderen over te brengen. Ik kijk met erg veel plezier terug op onze werkoverleggen, waar ik - en later ook samen met Florens - veel meer energie van kreeg dan dat het kostte.

Dr. F.G.A. Versteegh, beste Florens, het onderzoek was op weg, maar kreeg de duw die het nodig had door jouw enthousiasme om jullie kinderafdeling in Gouda erbij te betrekken. Op elk moment van de dag is met jou te overleggen over kinkhoest en kinderinfectieziekten. Mails met de laatste literatuur kwamen vaak van jouw kant. Fijn; je relativerende en onconventionele blik op de in onze ogen soms té kritische reviewers, die de schoonheid van ons werk niet altijd direct konden inzien. Voor hen tien anderen zei je dan. Heerlijk op zo'n moment.

Prof. dr. R. de Groot, beste Ronald, toen ik twee jaar geleden bij je kwam, was het uitzicht op een goede academische afloop van dit project op dat moment voor mij niet vanzelfsprekend. Jij nam de begeleiding op je om uiteindelijk tot dit proefschrift te komen. Je doet wat je zegt en ik waardeer je daar bijzonder voor. Je snelle reactie op mijn mails geeft het begrip "directe feedback" niet alleen de bekende figuurlijke betekenis, maar doet ook recht aan de letterlijke betekenis. Veel dank daarvoor!

Leden van de manuscriptcommissie, prof. dr. H.F.L. Wertheim, dr. ir. C.J.A. Roeleveld en prof. dr. L.J. Bont, hartelijk dank voor het beoordelen van mijn proefschrift. Leden van de beoordelingscommissie, dr. J.G. Ferwerda, dr. P.L.A. Fraaij, prof. dr. 
M. de Hoog, prof. dr. A.C.M. Kroes en prof. dr. J.J. Roord, hartelijk dank voor jullie bereidheid om zitting nemen in de beoordelingscommissie.

Alle co-auteurs van de verschillende hoofdstukken dank ik voor het vele denk,overleg- en schrijfwerk en de fijne manier waarop dat ging: Anne Russcher, Esther van der Berg, Tessa van Wijk, Gertrude van den Brink en Jacob Douma.

Tjeerd van der Ploeg, beste Tjeerd, jou dank ik voor je vermogen om statistische abstracties tot leven te laten komen voor praktische dokters zoals ik. Dank voor je lessen statistiek in Delft en de leuke werkoverleggen bij jou in Alkmaar!

Miranda en Anouk, dank voor de prachtige Delftse cover!

Leo Smeets en Rolf Vreede, jullie stonden garant voor een vlekkeloze samenwerking tussen de kliniek en het microbiologisch laboratorium. Perry van Wunnik en Marjon van Merrienboer dank ik daarnaast voor het logistiek- en laboratoriumwerk in Delft.

Kinderartsen in Gouda, veel dank voor jullie inclusies van patiënten. Extra werk in de toch al drukke winter. Ria en Zamire, dank voor jullie logistiek werk in Gouda.

De Wetenschappelijke Activiteiten Commissie (WAC) van ons ziekenhuis dank ik voor de financiële en inhoudelijke steun. En voor het jarenlange vertrouwen in een voorzitter zonder doctor-status.

Collega Delftse kinderartsen, Boudewijn, Annette, Loekie, Marion, Nico, Laura, Jeroen, Simone, Leonieke, Claire, Dirk en Hans, dank voor de ruimte die ik van jullie kreeg, jullie vertrouwen, meewerken, gunfactor, domoko's; regionaal beter bekend als ons "warme bad". Karin, veel dank voor jouw geweldig werk voor onze vakgroep. Ook daardoor heb ik tijd gehad om aan dit proefschrift te werken!

Paranimfen, Leonieke en Patrick. Paranimfen kies je uit omdat "het 100\% goed zit". Zo denk ik over jullie. Veel dank voor al jullie werk en ideeën!

Lieve familie en vrienden, heel veel dank voor al jullie interesse!

Lieve Oscar, Eva en Ruben. Dokter is met bloed...... En waarom zou je doctor willen worden, als je al dokter bent? Verder wel een leuk beroep....

"Kicks voor niks". Jullie manier van kijken en vragen leert me er nog eens extra over te denken.

Veel liefs!

Lieve Mardi, wij krijgen energie van dat wat we allemaal uit één dag weten te halen. Je kent me beter dan ik zelf; je steun is geruisloos en onvoorwaardelijk. Een auteursplaats bij elk van de artikelen was meer dan terecht geweest. Ik hou van je! 


\section{CURRICULUM VITAE}

Jérôme Oscar Wishaupt werd geboren op 7 februari 1973 te Maastricht. Na het behalen van zijn atheneumdiploma aan het Jeanne d'Arc College begon hij in 1991 aan de studie Biomedische Wetenschappen aan de Universiteit Leiden. Een jaar later startte hij met de studie Geneeskunde aan de zelfde universiteit alwaar op 11 december 1998 het artsexamen werd behaald. Zijn eerste wetenschappelijke ervaring werd opgedaan door het doen van immunologische studies naar het ontstaan van gewrichtsontstekingen bij de vakgroep Reumatologie van het LUMC te Leiden onder leiding van prof. dr. P.P. Tak.

In 1999 en 2000 was hij achtereenvolgens arts assistent op de afdeling kindergeneeskunde in het Sint Clara Ziekenhuis te Rotterdam (hoofd dr. E.J.A. Gerritsen), tegenwoordig het Maasstadziekenhuis en op de afdeling Neonatologie van het ErasmusMC - Sophia Kinderziekenhuis (hoofd prof. dr. L. Zimmerman) te

Rotterdam. De opleiding tot kinderarts werd ook gedaan in het ErasmusMC - Sophia Kinderziekenhuis (opleider prof. dr. H. Büller, later prof. dr. A.J. van der Heijden). De stage algemene kindergeneeskunde volgde hij in Reinier de Graaf in Delft (opleider dr. N. van der Lely).

In 2005 startte hij als kinderarts in het zelfde Reinier de Graaf. Op wetenschappelijk gebied was er - naar eigen zin - nog te weinig gedaan in zijn kindergeneeskundige carrière. In 2007 werd daarom begonnen met dit promotieonderzoek. Het onderwerp moest kinder-infectieziekten zijn, een praktische inslag hebben en een brede toepassing voor de kinderarts hebben. Het onderzoek werd begeleid door dr. N.G. Hartwig, Erasmus MC - Sophia Kinderziekenhuis, later Franciscus Gasthuis en Vlietland, dr. F.G.A. Versteegh, Groene Hart Ziekenhuis, Gouda en door prof. dr. R. de Groot, Radboud UMC, Nijmegen. De resultaten werden gepresenteerd op diverse medische congressen en staan beschreven in dit proefschrift.

Binnen het Reinier de Graaf is hij voorzitter van de Wetenschappelijke Activiteiten Commissie, lid van het innovatieplatform en sinds 2013 medisch manager van de vakgroep Kindergeneeskunde.

Hij is getrouwd met Mardi Brouwer en vader van Oscar (2002), Eva (2005) en Ruben (2006). 


\section{LIST OF PUBLICATIONS}

Wishaupt JO, Russcher A, Smeets LC, Versteegh FGA, Hartwig NG. Clinical impact of RT-PCR for pediatric acute respiratory infections: a controlled clinical trial. Pediatrics 2011 Nov; 128(5):e1113-20.

Wishaupt JO, Van den Berg EAN, Van der Ploeg T, Versteegh FGA, Hartwig NG. Risk for apneas in pediatric acute respiratory tract infections; 31th meeting of the European Society for Paediatric Infectious Diseases (ESPID), Milan, 2013, may 31 - june 1. Poster.

Van den Brink G, Wishaupt JO, Douma JC, Hartwig NG, Versteegh FGA. Bordetella pertussis: an underreported pathogen in pediatric respiratory infections, a prospective cohort study. BMC Infectious Diseases 2014 Sep 30; 14:526.

Wishaupt JO, Versteegh FGA, Hartwig NG. PCR testing for paediatric acute respiratory tract infections. Paediatric Respiratory Reviews 2015 Jan; 16(1):43-8. Review.

Wishaupt JO, Versteegh FGA, Hartwig NG. Virale diagnostiek voor acute luchtweginfecties bij kinderen. Praktische Pediatrie 2015, nummer 2, juni.

Wishaupt JO, Van der Ploeg T, Smeets LC, De Groot R, Versteegh FGA, Hartwig NG. Pittfalls in interpretation of CT-values of RT-PCR in children with acute respiratory tract infections; 7th edition of Excellence in Pediatrics, London, 2015, december 10-12th. Poster.

Wishaupt JO, van den Berg EAN, van Wijk T, van der Ploeg T, Versteegh FGA, Hartwig NG. Paediatric apnoeas are not related to a specific respiratory virus, and parental reports predict hospitalisation. Acta Paediatrica 2016 May; 105(5):542-8.

Wishaupt JO, van der Ploeg T, de Groot R, Versteegh FGA, Hartwig NG. Single- and multiple viral respiratory infections in children: disease and management cannot be related to a specific pathogen. BMC Infectious Diseases 2017 Jan 11; 17(1):62.

Wishaupt JO, van der Ploeg T, Smeets LC, de Groot R, Versteegh FGA, Hartwig NG. Pitfalls in interpretation of CT-values of RT-PCR in children with acute respiratory tract infections. Journal of Clinical Virology 2017 May; 90:1-6.

Hamann J, Wishaupt JO, van Lier RA, Smeets TJ, Breedveld FC, Tak PP. Expression of the activation antigen CD97 and its ligand CD55 in rheumatoid synovial tissue. Arthritis Rheumatism 1999 April; 42(4):650-8. 


\section{LIST OF ABBREVIATIONS}

\section{General}

ARI

CAP

CT

DFA

DDS

ED

LRTI

LOS

NWS

PICU

RT-PCR

URTI

\section{Pathogens}

FLU

Influenzavirus

$\mathrm{HCOV}$

Human Coronavirus

HAdV

HBoV

HMPV

PIV

RSV

RV

Human Adenovirus

Human Bocavirus

Parainfluenza Virus

Rhinovirus acute respiratory tract infection

community acquired pneumonia

cycle threshold (value) of RT-PCR

direct immunofluorescent antibody test

disease severity score

emergency department

lower respiratory tract infection

length of hospital stay

nasal wash specimen

paediatric intensive care unit

real-time reverse transcription-polymerase chain reaction test

upper respiratory tract infection

Human Metapneumovirus

Respiratory Syncytial Virus 

